\title{
DISPOSICIONES SOBRE LA CULTURA DEL CLERO PARROQUIAL EN LA LITERATURA DESTINADA A LA CURA DE ALMAS (SIGLOS XIII-XV)
}

\author{
José Marí SOTO RÁbanos \\ Centro de Estudios Históricos \\ (C.S.I.C., Madrid)
}

\begin{abstract}
SUMARIO
Prefacio.- I. Situación cultural del clero parroquial.- II. Opinión de los tratadistas.- III. Normativa sinodal.- IV. Detalle glosado de la normativa sinodal por áreas geográficas: A. Corona de Aragón. B. Galicia y Portugal. C. Castilla y León.
\end{abstract}

\section{PrefaCio}

La literatura destinada a la cura de almas es una literatura religiosa y, hasta cierto punto, popular.

Es literatura religiosa por su contenido básico, tanto doctrinal (teológico) como normativo (jurídico-canónico). Nos hallamos, en efecto, ante unos escritos que contienen las verdades de la fe cristiana y las disposiciones emanadas de la autoridad eclesial para la puesta en práctica de esa fe.

Es literatura popular porque su destinatario es el pueblo creyente, unas veces de forma directa, que suelen ser las menos, y otras de forma indirecta, a través de los sacerdotes curados, es decir, con cura de almas, encargados de la salud espiritual de los creyentes.

Puede denominarse también, con suficiente propiedad, literatura pastoral o, quizás mejor, literatura de teología pastoral, si bien esta terminología es más propia de nuestros días y aplicarla sin más a otras épocas podría considerarse un anacronismo.

No se trata de una literatura cultivada; quiero decir que los autores de este tipo de obras no las escriben para deleitarse o para deleitar mediante la utilización artística y ajustada de las palabras, o para convencer por la pro- 
fundidad, la agudeza y la trabazón de los argumentos, ni para dar a conocer o comunicar la amplitud de sus conocimientos.

El lenguaje utilizado es, por lo general, llano, de escaso valor para el arte del bien decir.

El contenido, variable de unos a otros en cuanto a la extensión y a la cantidad de los temas tratados, se mantiene dentro de unos límites determinados, en particular, por la finalidad concreta perseguida en cada caso y, en general, por razón de sus propios destinatarios.

Debido en una buena medida a las características señaladas, estos escritos han permanecido mucho tiempo, y algunos permanecen todavía hoy, inéditos o en el olvido, aunque no pocos tuvieran en su momento una gran difusión, primero manuscrita y luego impresa ${ }^{1}$.

Ese estilo sencillo de que hablamos, típico de la mayor parte de estos escritos, es intencionado. Son los propios autores quienes suelen precisar, ya en el proemio mismo de sus obras, que escriben así para que pueda aprovechar a cualesquiera personas, de cualquier estado o condición.

Cierto es, por otra parte, que esta declaración de intenciones, fuera de lo que tiene de modestia protocolaria, se refiere más a la voluntad de no entretenerse en consideraciones de envergadura que al estilo redaccional,es decir, más al contenido que a la forma.

Por ello, nos queda la duda, con referencia a algunos de estos autores, de quienes no conocemos otro tipo de escritos, de si, de pretenderlo, hubieran sido capaces de escribir, no ya sólo con mejor arte, sino también con mayor erudición, y con más profundidad y agudeza.

De cualquier manera, ellos dejan constancia expresa de que no pretenden la erudición ni el bien decir, sino ser entendidos por todos, simple y llanamente ${ }^{2}$.

Parte de esta literatura no es fruto de la reflexión intelectual de un teólogo o canonista en concreto, aunque intervenga con mayor o menor protagonismo, sino que emana de una actividad típicamente eclesial, asambleística; en ella, la Iglesia recoge su tradición doctrinal y normativa para urgirla en un momento y en un lugar determinados.

1 Es el caso de la obra Manipulus curatorum de Guido de Monte Roterio. Su gran difusión la pone de manifiesto H. SANTIAGo OTERo en sendos estudios: Guido de Monte Roterio y el <Manipulus curatorum>, en «Proceedings of the Fifth International Congress of Medieval Canon Law, Salamanca 1976», Citta del Vaticano, 1980, pp. 259-265; Guido de Monte Roterio. Nuevos manuscritos del <Manipulus curatorum>, en «Homenaje a Pedro Sáinz Rodríguez», vol. 1, Madrid, 1986, pp. 15-20.

2 Por ejemplo, Guido de Monte Roterio en la dedicatoria de su Manipulus: «Hec ergo attenta et uigili meditatione perpensans sequens opusculum de instructione neophitorum curatorum composui: rudi quidem stilo: sed utili non curans de uerborum ornatu: sed de animarum commodo et profectu» (Incunable Escorial, 61-VII-19 n.2, fol. 122 ra-rb). 
Me estoy refiriendo a la actividad conciliar/sinodal, que da lugar a una literatura propia, en la que, junto a disposiciones ocasionales sobre diversas facetas de la práctica de la fe de los cristianos, nos encontramos con los denominados libros sinodales, obras confeccionadas de forma ordenada y sistemática, que vienen a ser, de hecho, verdaderos manuales del arte de la cura de almas.

El interés de esta literatura para el investigador no es, exclusivamente, de carácter histórico-religioso. Los concilios y, más particularmente, los sínodos diocesanos, nos transmiten datos abundantes sobre la vida cotidiana, sobre costumbres locales, sobre conceptos y formas de vida; datos importantes, en una perspectiva histórica, para la sociología, la antropología, la economía, la política, etc.

Las notas o características aplicadas antes globalmente a esta literatura no alcanzan por un igual a los escritos que he tenido en cuenta en la elaboración de este trabajo.

Algunos de esos escritos quedan fuera, por superación, de las notas señaladas; concretamente, la Summa de casibus poenitentiae de Raimundo de Peñafort (primera mitad del siglo XIII), la Primera Partida de Alfonso X el Sabio (segunda mitad del siglo XIII) y el Speculum peccatoris confessoris et praedicatoris de autor anónimo (primera mitad del siglo XV), poseen un valor, en la forma y en el fondo, superior al de cualquier otro tratado o manual para la cura de almas. Sin embargo, su consulta para el caso es válida y casi obligada.

La Summa raimundiana, aun sin ser la primera en su género, da lugar, como es conocido, a una proliferación de obras de este tipo en toda la cristiandad, obras a las que sirve de guía.

La Partida alfonsina, aunque no va destinada a la cura de almas, recoge en romance castellano el organigrama eclesiástico de su tiempo, guarda un paralelismo notable con la Summa raimundiana y, en cuanto a la literatura que aquí nos ocupa, llena un vacío importante en la Península Ibérica en la segunda mitad del siglo XIII, pues, si bien no alcanzó valor legal hasta 1348 , consiguió pronto gran difusión e influencia, traspasando las fronteras del reino de Castilla y León ${ }^{3}$.

En cuanto al Speculum, se trata de una obra erudita, de un buen estudio sobre la restitución, pero está escrita expresamente para uso de los clérigos con cura de almas.

Por otra parte, me parece importante destacar que los tratados consultados constituyen un conjunto documental poco usual. En esta apreciación, dejo un poco aparte la Primera Partida y la Summa, que son obras suficiente-

${ }^{3}$ Cf. J. de Azevedo Ferreirs, Alphonse X. Primeyra Partida. Édition et Étude, Braga, 1980, pp. CXX-CXXIII: La diffusion des Siete Partidas au Portugal. 
mente conocidas; de los demás, dos permanecen inéditos: el Libro de las confesiones de Martín Pérez (primera mitad del siglo XIV) y el Speculum de autor anónimo; y otros dos alcanzaron ediciones incunables: el Manipulus curatorum de Guido de Monte Roterio (primera mitad del siglo XIV) y el Sacramental de Clemente Sánchez de Vercial (primera mitad del siglo XV).

En cuanto a la literatura derivada de la actividad sinodal, que es, cuantitativamente y por su importancia normativa intrínseca, la fuente documental básica de este trabajo, he examinado una muestra suficientemente amplia y significativa, a mi entender ${ }^{4}$.

Teniendo en cuenta que la incidencia normativa de los concilios y sínodos fue muy diversa según tiempos y lugares, me parece bien distinguir dos periodos respecto al comportamiento activo/pasivo de unas u otras diócesis y provincias eclesiásticas del territorio hispano en la etapa aquí consideradas.

El primer periodo comprende desde $1215 / 1229$ a $1322 / 1330$. En el concilio lateranense de 1215 culmina la dinámica de reforma de la disciplina eclesiástica, bien conocida con el nombre de reforma gregoriana y que para el periodo bajomedieval podríamos denominar, quizás mejor, con el nombre de reforma lateranense. Una de sus disposiciones más importantes a este efecto, desde un punto de vista instrumental o metodológico, es, sin duda, la relativa a la obligación de celebrar anualmente concilios provinciales y sínodos diocesanos.

En los reinos hispanos no hubo una acogida pronta y uniforme de esta

${ }^{4}$ Sólo cuando se haya completado la obra Synodicon hispanum, que edita la BiBLIOTECA De Autores Cristinnos bajo la dirección del Prof. Antonio García y García, de la que han aparecido, hasta el momento en que escribo, cinco volúmenes con los sínodos del oeste peninsular, la consulta de esta literatura estará al alcance normal de los investigadores interesados; aunque también hay, fuera de ella, algunas ediciones críticas de sínodos de diversas diócesis que, en lo que me ha sido posible, he consultado.

José Sánchez Herrero, atendiendo a otros criterios o fechas divisorias, como concilios ecuménicos y plenarios, el cisma y hechos políticos y económicos de importancia, distingue cuatro etapas, con varios tiempos en las etapas primera, segunda y cuarta, en la celebración de sínodos diocesanos entre los concilios de Letrán IV (1215) y Trento (1545-1563). Cf. de este autor: Los concilios provinciales y los sinados diocesanos esparioles, 1215-1250, "Quaderni Catanesi di scudi classici e medievaliw, año III, n.5 (1981), pp. 146-150 y 170-177; y Los sinodos y la catequesis, «Los Sínodos Diocesanos del Pueblo de Dios. Actas del V Simposio de Teología Histórica», Valencia, 1988, pp. 161-162.

6 c.6: «Sicut olim a sanctis patribus noscitur institutum, metropolitani singulis annis cum suis suffraganeis provincialia non omittant concilia celebrare... et quae statuerint, faciant observari, publicantes ea in episcopalibus synodis, annuatim per singulas dioeceses celebrandis».

Cito por la edición de Antonio Garcĺ y Garclı, Constitutiones Concilii quarti Lateranensis una cum Commentariis glossatorum, Città del Vaticano, 1981, p. 53. 
disposición. Trece años después del concilio lateranense, el legado papal Juan de Abbeville visita la Península, teniendo como objetivo fundamental el de urgir la normativa conciliar de reforma disciplinar. Con este fin, convoca a los obispos hispanos de las diversas provincias eclesiásticas y, reunidos en concilio, les va dictando las normas a seguir. De los concilios que celebró, quizá uno en cada provincia eclesiástica, sólo conocemos el texto de dos de ellos: el de Valladolid (1228), en versión romance tardía y, muy probablemente, incompleta, y el de Lérida (1229) .

La provincia eclesiástica tarraconense respondió positivamente, aunque no de inmediato, a este llamamiento; en 1239 inicia una serie razonablemente regular de concilios provinciales que culmina en 1330 en la recopilación del infante Juan de Aragón, patriarca de Alejandría y administrador perpetuo de la sede tarraconense.

Por otra parte, en sus diócesis sufragáneas se celebran sínodos con encomiable frecuencia, en comparación al resto de las diócesis hispanas durante este periodo, asumiendo las disposiciones del legado y de los concilios provinciales ${ }^{8}$.

Las dos diócesis principales de Portugal, es decir, Braga y Lisboa (ésta sufragánea de Santiago de Compostela hasta 1393), respondieron también de forma positiva, aunque no con la misma prontitud, al llamamiento del legado. Constituyen un testimonio elocuente las constituciones sinodales de Braga de 1281, 1285 y 1301; y las de Lisboa de 1240, 1248, 1264 y $1307^{9}$.

En cuanto a Galicia, en la diócesis metropolitana de Santiago de Compostela se tiene en cuenta la reforma lateranense desde la llegada misma del legado, pero sin entusiasmo. Se pueden establecer referencias de las disposiciones lateranenses y legatinas en los sínodos de Santiago de Compostela celebrados entre 1229 y $1322^{10}$.

7 Sobre el legado Juan de Abbeville, cf. Peter A. Lineran, La Iglesia española y el papado en el s. XIII, (versión castellana, revisada por el autor, a cargo de Pedro Borges Morán, Salamanca, 1975), pp. 17-29.

8 Sobre la influencia de las constituciones legatinas de 1229 en los concilios provinciales y sínodos de la tarraconense durante los siglos XIII y XIV, cf. T. NOGUER Y MUSQUERAS J.M. PONS GURI, Constitucions sinodals de Girona de la primera compilaci6, "Anales del Instituto de Estudios Gerundenses», 18 (1966-1967), pp. 49-55 y 84-86.

9 Todos ellos se hacen eco en sus textos respectivos de algunas constituciones lateranenses y legatinas. Además, el sínodo de Braga de 1281 , en las constituciones primera y quinta, y el de Lisboa de 1248, en la constitución sexta, mencionan expresamente al legado Juan de Sabina.

10 En la introducción al sínodo de 1229 (SH I. 263) A. García y García observa:»El arzobispo acababa de recibir la visita del legado pontificio Juan de Abbeville, cuyos planes de reforma no afloran excesivamente en este sínodo». 
En la diócesis exenta de León, según la documentación de que disponemos, inicia la aplicación de la reforma el obispo Martín Fernández (12541289) en un sínodo que celebró el año 1267 o el 1262, bien entrada ya la segunda mitad del siglo XIII ${ }^{11}$.

Respecto de las diócesis, también exentas, de Burgos y Oviedo, no hay constancia documental de que se celebraran sínodos en ellas durante este periodo; parece, pues, que no hubo respuesta positiva al llamamiento legatino.

Tampoco hubo respuesta positiva en las diócesis de la importante provincia eclesiástica de Toledo, al frente de la cual se hallaba Rodrigo Jiménez de Rada, quien en su Cbronicon recoge la presencia y la misión del legado en los reinos hispanos de forma escueta, protocolaria, sin manifestarse interpelado él mismo ${ }^{12}$.

El segundo periodo abarca desde los años $1322 / 1330$ hasta el concilio de Trento (1545-1563). El concilio legatino de Valladolid de 1322, convocado y presidido por el legado papal para el reino de Castilla y León, Guillermo Godin, cardenal de Sabina, recoge en buena parte las disposiciones de reforma que un siglo antes había intentado implantar en los reinos hispanos Juan de Abbeville, con tan poco éxito en el reino castellano-leonés, según ha quedado ya indicado.

Este nuevo intento obtuvo un mejor resultado: a partir de 1322, se inicia una reacción positiva de la Iglesia castellana, siendo el protagonista principal de la misma, sin duda alguna, el infante don Juan de Aragón, arzobispo de Toledo entre 1319 y 1328.

La iglesia tarraconense, por su parte, continúa durante el siglo XIV a buen ritmo, ascendente en principio y descendente luego, desde el último tercio del siglo, su actividad conciliar y sinodal, siendo el punto de referencia el corpus constitucional de 1330 del citado infante Juan de Aragón, el cual gobernaba desde 1328 la sede tarraconense en calidad de administra-

1 SH III, 232-253.

12 Lib.IX cap.XII fol.LXXXII $\mathrm{r}$ : «Eo tempore \{cuando la tercera incursión de Fernando III en tierras islámicas\} erat in Hispanijs legatus Romanae ecclesiae Iohannes de Abbatis villa, quae est in Comitatu Pontini, Sabinensis Episcopus Cardinalis, vir bonus, sapiens, literatus, qui celebratis in singulis regnis consilijs, postquam monita salutis proposuit, ad Sedem Apostolicam est reversus, tribus annis legationis expletis» (Rerum gestarum in Hispania Cbronicon, Granada, 1545).

Cf. A. Garcla y Garcla, Primeros reflejos del Conc. 4 Lateranense en Castilla, «Studia historico-ecclesiastica: Festgabe für Prof. Luchesius Spätling», Roma, 1977, pp. 249-282; artículo publicado también en la obra del mismo autor, Iglesia, Sociedad y Derecho, vol. 2 (Salamanca, 1987), pp. 209-235. Se trata aquí del sínodo que el obispo de Segovia Giraldo celebró, probablemente a finales del año 1216, siendo éste el primer intento de aplicar el espíritu de la reforma lateranense, tarea en la que no tuvo éxito. 
dor apostólico con el título de Patriarca de Alejandría y dio un nuevo impulso a la celebración de sínodos en su archidiócesis ${ }^{13}$.

Durante el siglo XV disminuye muy sensiblemente la actividad conciliar/sinodal de la archidiócesis tarraconense; asimismo, disminuye algo en Portugal y en algunas diócesis enclavadas en el reino de Castilla y León, mientras que aumenta en otras de este mismo reino ${ }^{14}$.

\section{SituACión CULTURAL DEL CLERO PARROQUiAL}

A principios del siglo XIII, la ignorancia del clero con cura de almas y su falta de dedicación, de profesionalidad, constituían un problema serio en los reinos hispanos.

Vicente Beltrán de Heredia, «después de haber valorado cual conviene los testimonios que hacen al caso", llega a la conclusión de que la Iglesia española, en líneas generales, "procuró atender decorosamente a la formación del clero" antes del concilio de Letrán de 1215, y después del concilio "puso singular empeño en su ejecución" ${ }^{15}$.

Peter Linehan rebate las conclusiones de Beltrán de Heredia y presenta un cuadro especialmente sombrío del clero español antes y después del Letrán IV en varios aspectos, siendo uno de los principales el de su incultura, de la que no se salvaban ni los obispos ${ }^{16}$.

Beltrán de Heredia se muestra deseoso de demostrar que el clero español tenía un nivel aceptable de cultura y, en función de este propósito, recoge y magnifica ciertos hechos y ejemplos aislados; además, se apoya más en lo establecido que en lo verdaderamente ejecutado respecto de la normativa lateranense y legatina, y en cuanto a los testimonios en los que

13 Sobre la figura del infante don Juan de Aragón cf. I. JANER, El Patriarca Don Juan de aragón, su vida y sus obras (1301-1334), Tarragona, 1904; A. LAMBET, Juan de Aragón y Anjou, «Dictionnaire d'Histoire et de Géographie Ecclésiastique», III, cols. 1408-1413; A. Risco, Algo sobre el infate Don Juan de Aragón y por qué renuncio al Arzobispado de Toledo, «Razón y Fe», 77 (1926), pp. 22-31, 107-117, 316-326; J. WINCKE, El traslat de l'arquebisbe Joan d'Aragon de la seu de Toledo a la de Tarragona, «Analecta Sacra Tarraconensia», 6 (1930), pp. 127-130; R. Avezou, Un prince aragonais, arcbeveque de Tolede au XIVe siècle Don Juan de Aragon y Anjou, «Bulletin Hispanique», 32 (1930), Pp. 26-371; J.F. RIVERA ReCIO, Aragón, Juan, infante de, «Diccionario de Historia Eclesiástica de España», t. I, Madrid, 1972, p. 76.

${ }^{14}$ Cf. J. SÁNCHez HerRero, obras citadas en nota 5.

is La formación intelactual del Clero en España durante los siglos XII, XIII y XIV, «Revista Española de Teología», 6 (1946), p. 314. V. Beltrán de Heredia se remonta en sus consideraciones a la normativa del concilio de Coyanza de 1055 y de los concilios compostelanos de 1060 y 1063, que engarzan con las disposiciones de los concilios tercero y cuarto de Letrán.

16 ob. cit., pp. 24-29 y 206-208, principalmente. 
aparece marcada la ignorancia clerical española los considera, en gran parte, como exageraciones retóricas.

Por el contrario, Peter Linehan ofrece testimonios y datos más concretos, aunque en algún caso va más allá de lo que permite el texto en el que se basa; por ejemplo, atribuye a Diego García la afirmación de que los obispos castellanos de la época eran «un puñado de ignorantes" ${ }^{17}$; y la verdad es que dicho autor no afirma tal cosa, ni en los lugares citados por Peter Linehan, ni en ningún otro de su Planeta.

Es cierto que Diego García arremete con gran dureza contra los obispos en más de una ocasión, tachándolos de personas engreídas, maliciosas, soberbias, insolentes y deficientes en honestidad y en ciencia ${ }^{18}$; pero todos estos calificativos (por lo demás, llenos de retórica, como hace notar oportunamente Manuel Alonso en el estudio introductorio a la edición de la obra ${ }^{19}$ ) no van dirigidos a los obispos castellanos, ni a los españoles, en particular, sino a los obispos todos de la Iglesia, en general.

Refiriéndose Diego García, ahora ya en concreto, a los obispos españoles, afirma que se comportaban en determinadas cosas como paganos y que pecaban de endiosamiento ${ }^{20}$.

De todas formas, la fama de inculto que se atribuye al clero español de ese tiempo está bien documentada; al menos, respecto del clero bajo y, concretamente, del clero encargado de la cura de almas, con referencia principal al clero de iglesias parroquiales y con menor incidencia sobre el clero de iglesias catedrales y de colegiatas, que estaban mejor dotadas y, por ello, disponían de más posibilidades para contratar maestros, para crear estudios y para enviar a sus clérigos a estudiar ${ }^{21}$.

El legado papal Juan de Abbeville se hace eco de esa fama y, siguiendo la pauta marcada por los concilios lateranenses III y IV ${ }^{22}$, establece un

17 Ibid., p. 26: «Diego García había descrito a los obispos castellanos como a un puñado de ignorantes». En la nota hace constar la obra y el lugar: «Planeta, 197, 405».

${ }_{18}$ Diego Garcín, Planeta. Edición, introducción y notas por M. Alonso, Madrid, 1943, pp. 184-186, 197, 405-406.

${ }_{19}$ pp. 110-116.

20 pp. 184-185: «<Scribo> Quando hyspaniarum episcopi quod verecunde assero hyspanus de hyspanis, circa quedam gentiliter barbarizant. Quippe non satis est hyspano episcopo: quod sufficit crucifixo...Sane hoc meo iudicio ab hydolatria non est penitus alienum, quando nomen creatori magis debitum quam exhibitum: creature, proh pudor, vilissime exhibeturn.

${ }^{21}$ Para Navarra, por ejemplo, lo pone de manifiesto el estudio de J. GoÑI GAzTAMBIDE, La formación intelectual de los navarros en la edad media (1122-1500), "Estudios de Edad Media de la Corona de Arag6n», X (1975), pp. 143-287; principalmente, pp. 167177. 74-75).

22 Letrán III, cc.3 y 18 (COD 212 y 220); Letrán IV, cc.11, 27 y 30 (García 59, 72-73, 
mínimo exigible de ciencia para los clérigos hispanos, mínimo que se concreta en una frase que se irá repitiendo día a día hasta hacer historia: saber hablar en latín ${ }^{23}$. Además, alienta y promociona la adquisición por parte del clero de un saber más amplio, mediante la creación de estímulos materiales concretos para los que lo deseen y lo intenten; dichos clérigos, durante su estancia en el estudio, percibirán íntegramente los frutos de sus beneficios, por un tiempo máximo de tres años ${ }^{24}$.

Los estudios de aprovechamiento aquí previstos por el legado no tienen por objetivo primario el alcanzar grados, sea de bachiller, licenciado o doctor, sino el más modesto de llegar a un aprendizaje mejor de la lengua latina, hasta hablarla y construirla bien, con soltura, en la esperanza de que, cuando menos, aprenderían el latín suficiente para poder servir dignamente su beneficio o encomienda.

Un siglo más tarde, el legado papal para el reino de Castilla y León, Guillermo Peyre Godin, en el concilio de Valladolid de 1322, insiste en la misma normativa de exigencia de un mínimo para todos y de estímulo al aprovechamiento para aquellos que manifiesten voluntad y aptitudes, permitiendo ampliar el plazo de tres años, a juicio de obispo y cabildo ${ }^{25}$.

${ }^{23}$ Valladolid 1228, c. $<3>.<1>$ (Tejada III, 325): «Stablecemos, que todos Beneficiados que non saben fablar latin, sacados los vieios, que sean constreñidos que aprendan, et que non les den los Beneficios fasta que sepan fablar latin... que los que non quisieren aprender, non sean ordenados de corona, et que non sean de quatro grados fasta que sepan fablar latin».

LErida 1229, c.6 (Noguer-Pons 64-65): «Statuimus quoque ut omnes beneficiati et promovendi in ecclesiis parrrochialibus qui latinis verbis loqui nesciunt, exceptis illis de quorum profectu per etatem non est sperandum in studio, ab episcopo et archidiacono loci, ubi tale ius consuevit habere archidiaconus, per substractionem beneficiorum quousque latinis verbis loqui sciant adiscere compellantur... Ad quartum autem gradum nullus omnino clericus secularis promoveatur qui latinis verbis loqui nesciat".

24 Valladolid 1228, c.<3>.<2> (Tejada III, 325): «Otrosi dispensamos con todos aquellos que quisieren estudiar, et aprovechar en Gramática, que hayan los Beneficios bien et entregamiente en las escolas, de la fiesta de San Luchas fasta tres años, se hi oviere otros Clérigos por que la Eglesia sea servida. Et se fasta este termino non sopieren fablar latin, non hayan los beneficios, fasta que emienden la sua negligencia por estudio, et fablen latin».

Lírida 1229, c.6 (Noguer-Pons 64-65): «Illis autem qui studere in gramatica et profiscere voluerint, misericorditer indulgemus ut beneficia sua integre in scolis habeant a proximo festo sancti Iohannis usque ad triennium, ac si in suis ecclesiis deservirent, proviso tamen ne ecclesia remaneat debito servitio desolata. Qui vero infra hunc terminum non tantum proficere curavit, quod latinis verbis loqui sciat quia suam maxime neglexerit ignorantiam, donec talem negligentiam per subsequens studium correxerit, beneficio suspendatur eodem*.

${ }^{25}$ c.9.<2> (Tejada III, 487): «Cum in personis Ecclesiasticis ad sacros ordines et Beneficia curam animarum habentia promovendis, idoneitas major requiratur, et amplior desideretur peritia literarum statuimus, ut nullun deinceps Clericus ad sacros ordines promoveatur, nisi saltem literaliter sciat loqui. Quod si forte secus actum fuerit, Praelatus a 
En la línea de estas disposiciones, la razón de estudio figurará expresamente en muchos sínodos como uno de los casos exceptuados de la norma general que obligaba a la residencia de los beneficiados y curados en sus beneficios y encomiendas.

Evidentemente, el propósito lateranense y legatino es elevar el nivel cultural de todo el clero, haciendo comenzar la exigencia del aprendizaje desde antes de ser clérigo, como requisito para llegar a serlo, de manera que «los que non quisieren aprender, non sean ordenados de corona ${ }^{26}$.

Esta normativa eclesial y su posterior evolución durante la baja edad media desembocará en la institucionalización del seminario en el concilio de Trento ${ }^{27}$. Pero, mientras tanto, su traducción a la normativa diocesana y a la práctica cotidiana pasa por estadios muy diversos, según se constata a través de la documentación sinodal.

\section{OPINIÓN DE LOS TRATADISTAS}

\section{a) Summa de casibus poenitentiae, de Raimundo de Peñafort ${ }^{28}$}

Por su autoridad como jurista canonista, y por su vinculación al poder pontificio y al legado Juan de Abbeville, a Raimundo de Peñafort se le debe considerar sin duda alguna un trasmisor especialmente cualificado de la normativa eclesial.

collatione sacrorum ordinum, quos tali contulit, et promotus ab executione suscepti ordinis per annum noverint se suspensos, nisi ex causa rationabili, et multum necessaria, quatenus de Jure conceditur, Praelatus super hoc viderit dispensandum».

c.21 (Tejada III, 498-499): «Ignorantia, quae mater cunctorum errorum esse dignoscitur... est diligentius evitanda... statuimus ut in qualibet civitate, et in aliis locis insignibus... ponantur magistri in grammatica, qui scholares in dicta scientia instruant, et informent. In civitatibus vero solemnioribus magistri in logica deputentur... Ut autem clerici ad proficiendum in scientia facilius inducantur, statuimus, quod volentes studio Literarum insistere, pro tempore, quo insistent, eisdem fructus beneficiorum suorum usque ad triennium percipiant, aut etiam majori tempore, si hoc Praelatis, et suis Capitulis expediens videatur... Cathedrales Ecclesiae personis literatis, providis et discretis indigent... statuimus, ut in qualibet Cathedrali, et Collegiata Ecclesia aliqui certi ex Beneficiatis apti... saltem unus ex decem de residentibus assumantur; qui ad studia generalia Theologiae, Juris Canonici ac liberalium artium accedere compellanturw.

26 VEase nota 23.

27 Los antecedentes del seminario en la Península Ibérica se remontan a la escuela sacerdotal visigoda de que se da noticia en el concilio II de Toledo, del año 527, según F. MARTÍN HERNANDEZ, Escuelas de formación del Clero en la España visigoda, «Actas de la XVIII Semana Española de Teología», Madrid, 1970, p. 65-98.

28 Cf. P. Ribes Montané, San Ramón de Peñafort y los estudios eclesiásticos, «Analecta Sacra Tarraconensia», 48 (1975), p. 85-142; especialmente, pp. 110-114. 
Raimundo de Peñafort plantea el tema de una manera puramente teórica; apunta al deber ser, sin entrar en detalles sobre la situación, ni sobre formas concretas posibles de poner en práctica la normativa, ni sobre el cumplimiento de la misma. Como punto de partida teológico recurre a san Pablo y a los santos padres; el apoyo jurídico lo toma del Decreto de Graciano y de las Decretales, que él mismo compiló por encargo del papa Gregorio IX.

Raimundo hace referencia genérica al ordenando, sin especificar ni diversificar grados de orden; pero es claro que tiene presente la idea de que el ordenando lo es en tanto en cuanto su objetivo, la finalidad de su ordenación, es el servicio divino y la cura de almas.

A partir del texto paulino, referido directamente al obispo y que debe aplicarse por extensión a los demás clérigos ${ }^{29}$, bajo la cualidad de la prudencia, al ordenando se le exige que sea perito en tres vertientes del saber: conocimiento de las Escrituras y de la disciplina eclesiástica, es decir, de la teología y del derecho canónico; conocimiento de las ciencias profanas; y conocimiento de los asuntos mundanos ${ }^{30}$.

En cuanto al saber escriturario y eclesiástico, no se precisa ulterior motivación; se justifica en si mismo, pues se orienta justamente a lo que corresponde al clérigo, o sea, al culto divino y a la cura de almas. Precisamente, para facilitar la adquisición de estos conocimientos se ha establecido que en las iglesias metropolitanas haya doctores para enseñar teología, y que los clérigos que acudan a ellas para realizar los estudios teológicos perciban íntegros sus estipendios; y si éstos no bastaran para costear los estudios, las iglesias a las que estén adscritos se harán cargo de lo demás que necesiten (alusión clara a becas de estudios), siempre que tales clérigos se comporten honestamente y aprovechen en el aprendizaje ${ }^{31}$.

29 Summa lib.3 tit.1 (p. 258): «Licet autem apostolus videatur regulam in episcopo posuisse, tamen, vt ait Augustinus, et etiam Ambrosius, inducens ad probandum auctoritatem Niceni Concilij, extendenda est ad alios ordinandos».

Cito por la edición de la Summa hecha en Roma el año 1603, cuya paginación incluyo entre paréntesis.

30 Ibid., lib.3 tit.5 (p. 268): «Oportet et ordinandum esse prudentem: debet enim habere triplicem peritiam, videlicet sacrae scripturae... secularium litterarum... secularium negotiorum».

${ }^{31}$ Ibid., lib.3 tit.5 (p.268): «Et propter hoc statutum est, vt in Ecclesijs metropolitanis teneantur doctores Theologiae; et quod clerici exeuntes prouinciam ad audiendam Theologiam percipiant integra stipendia: immo et si non sufficiunt eis sua, et illi honesti sunt, et bene addiscunt, debet Ecclesia sibi necessaria ministrare». Sobre lo mismo en lib.1 tít.3 \&.1 (p.30).

El glosador, y contemporáneo, de Raimundo, Guillermo Redonense, anota, en ambos lugares, que este estatuto se observaba mal:»Hoc statutum, et caetera statuta de duobus magistris male observatur», «Sed male obseruantur hodie ista statuta». 
El hecho de salir de la propia metrópoli para estudiar podría obedecer a la carencia en ella de suficientes teólogos capacitados y disponibles y/o a la carencia de organización escolar adecuada: financiación inicial, locales para la enseñanza, residencias para los estudiantes, biblioteca, costes de mantenimiento, etc.; o bien al deseo del clérigo de estudiar en un centro escolar de mayor prestigio: Bolonia, París, Salamanca, etc. La advertencia anotada de Guillermo Redonense sobre el mal cumplimiento de la norma avala la primera posibilidad, aunque también hay que tener en cuenta que las normas sobre el estudio se entienden con gran amplitud respecto a respetar, dentro de lo posible, la voluntad de elección de cada clérigo ${ }^{32}$.

De todas formas, la propuesta de Raimundo no se orienta, al menos de forma prioritaria, a la adquisición de grandes saberes o títulos de ciencia teológica, sino a conseguir los conocimientos suficientes para poder recibir las órdenes y ejercitar dignamente la cura de almas; es la propuesta del lateranense IV, que Raimundo recoge al pie de la letra ${ }^{33}$.

$\mathrm{La}$ exigencia de pericia en las ciencias profanas es solamente instrumental, como medio necesario para llegar al conocimiento de la teología, a la scientia pietatis. Los maestros de las artes liberales, que debe haber en las iglesias catedrales y en otras iglesias con posibilidades económicas ${ }^{34}$, no tienen obligación de enseñar a los ordenandos más que el trivium, es decir, gramática, dialéctica y retórica, ya que sólo estas disciplinas sirven a los hombres de cara a la scientia pietatis, que es la que interesa en el caso. Las materias del quadrivium, o sea, aritmética, geometría, música y astronomía, no son malas ni falsas; simplemente, no llevan a la piedad, no conducen a la devoción espiritual. Como norma general, no se prohibe el estudio de estas asignaturas, pero queda fuera del programa oficial que se dibuja para el curado. También se admite la lectura de autores paganos, así como el estudio de leyes y de medicina, excepto para algunos, entre los que se cuentan, ciertamente, los clérigos curados ya sacerdotes ${ }^{35}$.

El estatuto a que se refiere es el promulgado en el concilio de Letrán de 1215, c. 11 (García 59), incorporado a las Decretales por el mismo Raimundo de Peñafort (X 5.5.4 : Friedberg II, 770).

32 El obispo de Calahorra, Jerónimo Aznar (1238-1263), en el sínodo de 1240, c.31 (Bujanda 124), da libertad a los clérigos para que puedan acudir a escuelas generales, «así como a Bolonia, o a París, o a Tolosa, o a Calahorra», sin señalar preferencia alguna por su parte.

33 Summa lib.1 tít.3 \&.1 (p. 30): «Item quod Metropolitana Ecclesia Theologum nihilominus habeat, qui Sacerdotes, et alios in sacra pagina doceat; et in ijs praesertim informet, quae ad curam animarum spectare noscuntur» (= Letrán IV, c.11: García 59).

${ }^{34} \mathrm{La}$ glosa de Guillermo Redonense sobre el mal cumplimiento del estatuto mencionado en nota 31 afecta igualmente a esta otra disposición.

${ }^{35}$ Summa lib.3 tit.5 (p. 268-269): «Ideo etiam statutum est, vt teneantur magistri liberalium artium... hoc tamen non intelligas de omnibus liberalibus artibus,sed de triuiali- 
La pena de excomunión que acompaña a la prohibición de estudiar leyes y medicina no afectaba, en opinión del glosador de Raimundo, a los clérigos con cura de almas que aún no habían sido ordenados de sacerdotes $^{36}$.

En otro lugar de la Summa, Raimundo se conforma con que en las iglesias catedrales, y en otras con posibilidades, haya maestros de gramática: "Quod singulae Ecclesiae Cathedrales tenerent singulos magistros liberalium artium, ad minus grammaticae ${ }^{37}$.

En efecto, la gramática aparece como la disciplina principal en la disposición del lateranense IV:»Constituatur magister idoneus... qui clericos ecclesiarum ipsarum et aliarum gratis in grammatica facultate ac aliis instruat iuxta posse" ${ }^{38}$.

La exigencia de pericia en los negocios seculares es asimismo instrumental, en cuanto hace falta para atender a los súbditos en los asuntos temporales, puesto que "non solum spiritualia, sed etiam temporalia debet subditis, et necessitatem patientibus ministrare ${ }^{39}$.

Se apunta, en el texto citado, a la capacitación para el buen gobierno de los fieles y para la correcta administración de los bienes de las iglesias.

La ignorancia, aún total, no invalida la recepción de la orden, pero impide el ejercicio de la misma, ya que "sine litteris non potest fieri» ${ }^{40}$.

A los ignorantes que, por una u otra causa, hayan conseguido ordenarse, se les dará un ayudante o se les exigirá que dimitan del oficio, según los $\operatorname{casos}^{41}$.

bus tantum,scilicet Grammatica, Dialectica,et Rhetorica,quia illae specialiter ducunt, et erudiunt homines ad scientias pietatis. Secus in quadruuialibus ... quia illae, licet in se contineant veritatem, non tamen ducunt ad pietatem... Item auctores gentilium... propter eandem causam, qua triuiales scientiae... Leges autem, et physicas possunt audire ... nisi sint monachi, vel regulares, vel sacerdotes, vel habentes personatus, vel plebanatus, qui nullo modo possunt audire; et si audierint, ipso iure sunt excommunicati».

${ }^{36}$ Ibid., lib.3 tit.5 (p.269), en nota marginal / Personatus: «Nec intelligo clericos habentes simplicem curam animarum in ecclesiis parrochialibus, si nondum sunt sacerdotes, subiacere huic poenae (de excomunión ipso iure), si leges audierint, vel physicam».

37 Ibid., lib.1 tit.3 \&.1 (p.30).

38 c.11 (García 59). En el lateranense III, c.18 (COD 220), se habla de «legendi et proficiendi opportunitas», sin precisar más.

39 Summe, lib. 3 tit.5 (p. 269).

40 Ibid., lib.3 tit.5 (p.269).

${ }^{41}$ Ibid., lib.3 tit.5 (p.269): «In summa nota, quod sufficit vt habeat scientiam competentem, etsi non eminentem... Item propter simplicitatem repellitur quis ab obtinendo, sed non deijcitur ab obtento, immo datur ei coadiutor... Itemn propter illiteraturam potest Episcopus petere licentiam resignandi». 


\section{b) Primera Partida, de Alfonso X el Sabio ${ }^{42}$}

La Primera Partida recoge en substancia la misma normativa que la ofrecida por Raimundo, pero con algunas diferencias que paso a comentar.

Los saberes, cuya exigencia aplicaba Raimundo a los ordenandos en general, los legisladores de la Primera Partida los refieren a los obispos y demás prelados mayores, exclusivamente. Respecto a los clérigos no prelados, se conforman con señalar que los obispos no deben conceder beneficios eclesiásticos a aquellos que no tengan «letradura, e buenas costumbres" ${ }^{43}$, sin especificar más; sólo al tratar de los prelados mayores, detallan los conocimientos a tener.

Como principio general, el obispo debe ser letrado; no ya un gran letrado, «solo que sea letrado comunalmente, de guisa que cumpla el oficio que ha de fazern ${ }^{44}$.

Luego, precisa los saberes concretos. En primer lugar, debe ser entendido en la fe; en segundo lugar, debe ser entendido «en los saberes que llaman artes», o sea, en la gramática para saber latín, en la lógica para poder razonar y así distinguir la verdad del error, en la retórica para saber expresarse, y en la música para saber cantar en las iglesias ${ }^{45}$.

En el último punto, la música, la Primera Partida se desvía una vez más de lo señalado por Raimundo, el cual, siguiendo a Graciano (D.37 c.10), no incluye esta materia, que pertenece al quadrivium, entre los saberes obligados. El glosador de las Partidas, Gregorio López, anota oportunamente que, si bien la música no es una ciencia substancial para el obispo, conforme se recoge en Graciano, la ley alfonsina la incluye como adecuada al prelado, por causa del canto en la iglesia, lo cual es razonable ${ }^{46}$.

En efecto, como veremos más adelante en la normativa sinodal, el canto llamado llano, es decir, el canto gregoriano, se considera de gran importancia para los clérigos y se puede considerar incluido entre los estudios de gramática, en cuanto que ser gramático quiere decir: leer, cantar y construir con suficiencia. En tercer lugar, el obispo deberá ser entendido en los asun-

42 Utilizo la edición de Gregorio López, Salamanca 1555.

43 tít.16 ley 14.

44 tít. 5 ley 22. Según el glosador Gregorio López, apoyado en famosos canonistas, entre ellos Juan de Torquemada, el cumplimiento del oficio conllevaría conocimientos de la Escritura y del derecho canónico en grado suficiente; es decir, deberá saber, en cuanto a la Escritura, los artículos de la fe, los mandamientos divinos, las virtudes y los sacramentos; y en igual medida en cuanto al derecho canónico.

45 tít. 5 ley 37.

46 tít. 5 ley 37 , en glosa bajo la letra e: «Huius scientia non est substantialis multum in Episcopo, vt habetur in dicto canone si quis artem, sed ista lex tantum dicit, respectu cantus ecclesie, et bene stabit episcopo, si ad hoc Musicam sciat». 
tos temporales, "para saber bien gouernar sus obispados, e mantener sus pueblos" ${ }^{47}$.

\section{c) Libro de las confesiones, de Martín Pérez}

La fecha de composición de esta obra se sitúa en torno al año

$1320^{48}$. Martín Pérez recoge en breves líneas la normativa canónica sobre la ciencia clerical, siguiendo en lo substancial la pauta marcada por Raimundo de Peñafort.

El clérigo debe saber: algo de teología (santa escritura de Dios) para predicar y enseñar; gramática suficiente para leer sin falso en los oficios; y otras ciencias que le ayuden en su menester.

El clérigo no se debe detener, es decir, no debe profundizar, en las "ciencias menores", como son la gramática, la retórica, las naturales, la filosofía, la música, la aritmética, la astrología; en definitiva, en todas las otras ciencias fuera de la teología; detenerse el clérigo, como tal, en estas ciencias menores, más allá de cuanto le son necesarias para su oficio, para aparentar, sería pecado de soberbia ${ }^{49}$.

Es así como Martín Pérez recalca la simple instrumentalidad de los saberes no teológicos para el clérigo. No se detiene en marcar la diferencia entre el trivium y el quadrivium, ni hace referencia expresa a los negocios seculares, pero se entiende que éstos forman parte de esas otras ciencias que ayudan al clérigo en su menester.

Por lo demás, los tres extensos libros, de que consta la obra de Martín Pérez, contienen los saberes concretos que deben aplicar los curados en el ejercicio de su ministerio, a través, sobre todo, del sacramento de la penitencia, que da nombre al conjunto de la obra. Lo cual no quiere decir que tales curados deban saber de antemano cuanto en ellos se contiene; su con-

47 tít. 5 ley 37.

48 Sobre el autor y la obra, cf. A. GArcÍ y Garcf́ - J. M. Mugica, 0 Libro de las confesiones de Martín Pérez, "Itinerarium», 20 (1974), pp. 137-151; A. GARcÍ y GARcIA, Iglesia, Sociedad y Derecho, vol. 1 (Salamanca 1985), pp. 25-27.

Agradezco a los autores aquí citados que me hayan facilitado copia de una primera transcripción del texto de los tres volúmenes, uno por parte, de que consta la obra de Martín Pérez: la primera parte según el manuscrito 23, folios $14 \mathrm{r}-129 \mathrm{v}$, de la biblioteca de la Real Colegiata de San Isidoro de León; la segunda, por el manuscrito 21 , folios $2 \mathbf{v}-219 \mathbf{v}$, de esa misma biblioteca; y la tercera, por los manuscritos 7-4-3, folios 2 r - 137 v, y 7-7-2, folios 77 r - 240 v, ambos de la biblioteca Capitular y Colombina de Sevilla.

49 Parte $2^{\star}$ cap.XII (fol. 59 r): «Ca deue saber algo de la santa escriptura de dios para predicar et para enseñar las almas a beuir et guardar se de pecado. Et deue saber gramatica para leer sin falso en la eglesia... Et non se deue detener en las çiençias menores asy commo gramatica rretorica las naturas... para parescer; ca esto es soberuia». 
sulta les ayudará en cada caso a resolver la situación. Así, dichos libros se constituyen en el vademecum, en el libro de mano, de los clérigos curados.

\section{d) Manipulus curatorum, de Guido de Monte Roterio ${ }^{\text {so }}$}

Se observa en esta obra, compuesta el año 1333 según reza en la dedicatoria del autor al obispo de Valencia Raimundo"s, una estrecha dependencia de la Summa de Raimundo de Peñafort, a quien cita con frecuencia. Concretamente, respecto a la exigencia de pericia del ordenando en la triple vertiente del saber, sintetiza lo indicado por Raimundo, en el mismo orden y casi al pie de la letra.

Como matiz de aportación personal de Guido se puede señalar su insistencia en el estudio y conocimiento de la gramática, cuando, refiriéndose a las disciplinas del trivium, precisa: «et maxime de grammatica». No obstante, esto no significa que Guido piense que los clérigos deban ser unos excelentes gramáticos; simplemente, destaca la gramática como la más instrumental, entre las ciencias menores, para el clérigo ${ }^{52}$.

Lo dicho vale en términos generales para todo clérigo. Cuando se trata de "sacerdotes", Guido remite a una exposición algo más detallada, que ofrece en el proemio de la obra ${ }^{33}$.

En realidad, no es que Guido se extienda en más consideraciones, pero sí especifica mejor los saberes propios de los sacerdotes, y especialmente de los curados, conforme al oficio que éstos deben desempeñar, oficio que abarca cuatro apartados: celebración de la misa, administración de los sacramentos, audición de las confesiones, y enseñanza del pueblo.

Para atender al primero deben ser gramáticos, es decir, leer bien, pronunciar y acentuar adecuadamente, y entender, cuando menos ad litteram, materialmente, sin mayor discurso, lo que se contiene en el oficio de la misa; he ahí toda la razón de la importancia de la gramática, a la que ya Escorial.

so Utilizo el incunable 61-VII-19 n.2 de la Real Biblioteca de San Lorenzo de El

"11 fol. 1 ra-rb: «Reuerendo in christo patri ac domino:Raimundo diuina prouidentia sancte sedis Valentie episcopo...Scriptum turoli anno domini.M.ccc.xxxiii».

52 Pars 1 tractatus 5 caput 5 (fol. 34 va-vb): «Vnde ordinandus et promouendus ad regione (sic por regimen) animarum debet habere notitiam et peritiam sacre scripture ad animas informandas... Debet habere etiam peritiam scripturarum secularium, et hoc ad eruditionem ut possint discernere uerum a falso et per eas habere aditum ad theologiam... et intelligo de scientiis triuialibus, scilicet, grammatica logica rethorica et maxime de grammatica quia quadriuiales scientie, scilicet, arismetrica geometria musica et astronomia parum aut nihil faciunt ad scientias pietatisw.

${ }^{33}$ Pars 1 tractatus 5 caput 5 (fol. 34 vb): «De hoc, scilicet, quam scientiam debe $<n>t$ habere sacerdotes require supra in proemio huius libelliw. 
hemos aludido. No alude aquí al rezo del breviario o recitación de las horas, dado que su interés se centra en la vertiente ad extra, ad bomines, del ministerio sacerdotal.

Por razón del segundo, deben saber el número de los sacramentos, su materia y su forma y el modo de administrarlos.

Para oir las confesiones deberán saber discernir los pecados e imponer la penitencia oportuna.

Y para enseñar deberán conocer suficientemente los artículos y los demás rudimentos de la $\mathrm{fe}^{54}$.

Guido da por supuesto, demasiado generosamente, que los obispos no promueven al sacerdocio sino a aquellos que demuestran tener conocimientos teológicos y gramaticales suficientes; y da también por supuesto que los curas neófitos saben poco del oficio; pero esto es para él un hecho que no parece preocuparle mayormente, ya que dichos curas neófitos tienen a su disposición obras como la suya, además del libro sinodal, por las que, siendo suficientemente gramáticos, pueden aprender y ejercer correctamente el oficioss.

Sin embargo, no es tan optimista respecto del cumplimiento del requi-

54 Prologus (fol. 1 va-vb): «Quamobrem quicumque uult suum officium bene exequi debet scire que ad officium suum spectant. Officium autem sacerdotum maxime curatorum consistit in quattuor secundum quattuor ethimologias istius nominis... quia sacerdotes sunt missarum celebratores... sacrorum ministratores... confessionum auditores... plebis doctores... Ergo propter primum debent habere tamtum de scientia quod sciant recte et distincte legere et congrue pronunciare et accentuare: et ad minus grammaticaliter intelligere ea que in misse officio continetur. Propter secundum debent habere tantum de scientia quod sciant numerum sacramentorum et que sit debita forma et debita materia cuiuslibet sacramenti et modum ea debite ministrandi, potissime et sacramentis que ad eos spectant. Propter tertium debent habere tantum de scientia quod sciant discernere inter lepram et lepram, id est, inter peccatum et peccatum et penitentias imponere salutares. Propter quartum debent habere tantum de scientia quod sciant ad minus populum in articulis fidei et aliis rudimentis fidei informarex.

"Prologus (fol. 1 vb): «Omisso autem primo (se refiere al oficio de celebrar misa) quia illud spectat ad grammaticam et quia satis suppono quod sancti episcopi nullum ad sacerdotii ordinem promoueant: nisi sufficienter in grammaticalibus sit informatus... de tribus aliis in hoc libello est agendum: quem libellum uolui manipulum curatorum uocari ex eo quod sacerdotes potissime curati debent istum libellum portare in manibus: ut uideant ea que circa offitium sunt agenda».

En Pars 2 tractatus 2 caput 4 (fol. 56 ra), con relación a la absolución de los pecados reservados al obispo, menciona el libro sinodal que debe tener todo sacerdote curado: "Quae episcopi sibi retinent secundum quod eis uidetur expediens, de quibus non potest certa regula dari: sed unusquisque sacerdos curatus habeat sinodale suum: cum quo se dirigat in uia istax.

Sobre el poco saber de los curas neófitos, se pronuncia varias veces; por ejemplo, en folios $1 \mathrm{rb}, 1$ va, $36 \mathrm{va}, 45 \mathrm{va}, 84 \mathrm{vb}$. A ellos, precisamente, va destinado el Manipulus. 
sito de la edad legítima según el grado de orden. Denuncia que se promueve a órdenes sagradas incluso a imberbes y que se eleva al episcopado y al cardenalato a quienes no tienen edad ni siquiera para recibir el subdiacona$\mathrm{do}^{56}$.

\section{e) Sacramental, de Clemente Sánchez de Vercial ${ }^{57}$}

No se trata abiertamente en esta obra del tema de la ciencia clerical; pero, espigando aquí y allá, encontramos algunas referencias. De todas formas, el tema, como problema, subyace en cada página, ya que de forma similar a las obras de Martín Pérez y Guido de Monte Roterio, la obra de Clemente Sánchez tiene su origen en la notoria situación de ignorancia en la que se hallaban muchos sacerdotes curados de su tiempo, que no sabían ni lo que un buen cristiano debía saber ${ }^{58}$.

En el enfoque y tratamiento del problema se observa, como en Guido, un claro matiz pastoralista. Clemente se fija, no de forma exclusiva pero sí preferente, en la vertiente ad bominem de la acción sacerdotal.

Parte de que las condiciones o cualidades que san Pablo pide a los obispos (I Tim. 3.2-4; Tit. 1.6-9) se aplican por extensión a todos los que se ordenan, es decir, a todos los clérigos. Entre estas cualidades están la de ser letrado y la de saber enseñar la palabra de Dios, o sea, la doctrina cristiana ${ }^{59}$.

56 Pars 1 tractatus 5 caput 5 (fol. 34 ra): «Secundum quod requiritur est etas legitima, circa quod est sciendum quod licet doctores canonum faciant multas harengas circa materiam istam, uidemus tamen occulta fide temporibus nostris ad sacros ordines promoueri pueros in barbes: immo uidemus aliquos ad dignitates et personatus et autem ad episcopatum ad cardinalatum infra tempus taxatum ad subdiaconatus susceptionem promotos.

57 Obra acabada de escribir en marzo de 1423. Utilizo el incunable 75-VI-15 de la Real Biblioteca escurialense.

s8 fol. IX r: «E por quanto por nuestros pecados enel tienpo de agora muchos sacerdotes que an curas de animas non sola mente son ynorantes para instruyr e enseñar la fe e creencia e las otras cosas que pertenescen a nuestra saluacion. mas aun non saben lo que todo buen christiano deue saber nin son instruydos nin enseñados enla fe christiana segund deuian e lo que es mas peligroso e dañoso algunos non saben nin entienden las escripturas que cada dia an de leer e de tractar. E porende yo Clemen Sanches de Vercial. bachiller en leyes Arcediano de Valderas enla yglesia de Leon maguer pecador e indigno propuse de trabajar de fazer vna breue copilacion delas cosas que necessarias son alos sacerdotes que an cura de animas confiando dela misericordia de Dios».

59 fols. CLX v - CLXI r: «El que ha de rescebyr el sacramento dela orden deue aver estas condiciones... La quarta que sea letrado avn que non por excelencia... La septima que sepa enseñar la palabra de Dios... E estas cosas sobre dichas pone sancto Thomas en su conpendio. El apostol pone treze condiciones por otra manera... La quarta que sea sabio... E commo quier que el apostol puso estas condiciones alos obispos. pero deuen se estender a todos los que se ordenan segund dize sant Ambrosio e sant Agustin». 
Los clérigos, sobre todo los sacerdotes y prelados que tienen cura de almas, deben saber y entender las Santas Escrituras. En esta expresión queda resumida toda la ciencia que debe poseer un curado para informar en la fe, «por que por la su claridad los que biuen en estado de legos sean alunbrados» ${ }^{60}$.

En cuanto a la amplitud, profundidad y grado de personalización de estos conocimientos, Clemente no es exigente: el ordenando debe ser letrado, pero no por excelencia. Refiriéndose al conocimiento de los artículos de la fe, afirma que los clérigos curados deben saberlos a un nivel intermedio entre los simples fieles y los prelados mayores u obispos; los simples fieles los deben saber en bloque, en conjunto, brevemente, creyendo lo que cree la iglesia; los curados declaradamente, como se contienen en el credo; los prelados mayores. razonadamente, para poder dar respuesta si son preguntados ${ }^{61}$.

\section{f) Speculum peccatoris confessoris et praedicatoris (anónimo)}

De esta obra sólo se conoce un manuscrito, que se conserva en la Real Colegiata de San Isidoro de León, donde figura catalogado con el número $37^{62}$.

Escrita probablemente entre los años 1431 y $1435^{63}$, se propone desenmascarar los abusos (excesos, pecados) de clérigos y legos según categorías y profesiones, precisando en qué medida dichos abusos obligan a una restitución o satisfacción.

${ }^{60}$ fol. IX r: «Por lo qual los clerigos especialmente los sacerdotes e perlados que an cura de animas alos quales es dado de saber los misterios de Dios segund dize sant Luchas enel su euangelio son despenseros delos sacramentos dela santa madre yglesia. deuen saber $e$ entender las santas escripturas e deuen resplandecer en virtudes. por que por la su claridad los que biuen en estado de legos sean alunbrados".

${ }_{61}$ fol. XI v: «Todo christiano deue saber los articulos dela fe. commo quier que en diuersas maneras... Ca los legos los deuen saber breue mente creyendo lo que cree la santa madre yglesia. E los clerigos que han curas de animas mas clara e abierta mente segund se contiene enel credo in vnum deum. E los perlados mayores non sola mente los deuen saber bien declarados mas aun deuen dar razon dellos quando les fuere preguntadow.

Insiste en esta idea un poco más adelante, fol. XII v: «Estos catorze articulos asi breue mente dichos se deuen saber por todo christiano clerigo o lego. Pero más clara e mas larga mente se deuen saber por los clerigos que han cura de animas e por los perlados que han iurisdiciones». nota 82 .

Es la misma idea expresada años antes en el Liber Synodalis de Gonzalo de Alba. Cf.

${ }^{62}$ Cf. J. Pérez Lumazares, Catálogo de los Códices y documentos de la Real Colegiata de San Isidoro de Leon, León, 1923, p. 50.

${ }^{63}$ Sobre la datación de la obra, cf. J. M. Soto Rabanos, Derecho canónico y praxis pastoral en la España bajomedieval, «Monumenta Iuris Canonici», Series C: Subsidia, vol.7, Citta del Vaticano, 1985, p. 601 nt. 19. 
En ese contexto, el autor denuncia varias veces a los muchos clérigos curados de su tiempo que no son peritos en la cura de almas, como debieran, por haber alcanzado las órdenes y la cura de almas siendo ignorantes, en lo cual los obispos ordenantes y conferentes tienen, sin duda, la máxima responsabilidad.

No se detiene a precisar qué estudios debe realizar y qué grado de ciencia debe poseer o adquirir cualquier clérigo en general y el curado en particular; sin embargo, de las repetidas denuncias de lo que no saben se deduce lo que el autor entiende que deben saber. En una situación de normalidad, el clérigo encargado, o que va a encargarse, de la cura de almas debería tener estudios de teología y de derecho canónico y civil de una duración mínima de dos a tres años. Cuando menos, debería ser un buen gramático.

Ya en el proemio, al indicar la motivación y la finalidad de su obra, el autor se explaya en la consideración de la ignorancia generalizada de la clerecía encargada de la cura de almas y señala como principales culpables de la situación a los obispos quienes, guiados por sus intereses familiares y materiales, confieren la cura a simples e idiotas, que no saben cuidar ni de si mismos, y que necesitarían de curadores para la administración de sus bienes temporales. Y esto acontece, no sólo en las iglesias rurales y de castillos, sino también en las de villas y ciudades ${ }^{64}$.

Tratando de los pecados principales de los hombres del campo, comenta la opinión del Hostiense (Enrique de Segusio) acerca de la via tutior de los rústicos sobre los que tienen a mano riquezas y ociosidad, en referencia a los habitantes de villas y ciudades, y matiza que lo dicho por el Hostiense pudo ser verdad en su tiempo, pero que en la actualidad algunos rústicos incluso sobrepasan en malicia a los que viven en villas y ciudades. Lo interesante del caso es que, para nuestro autor, la culpa de la malicia rústica la tienen los prelados por conferir órdenes y beneficios curados a clérigos del

${ }^{64}$ Fol. VI r: «Quod precipue accidit (que se condenen muchas almas por la invalidez de su penitencia) ex negligencia prelatorum, qui carnalitatis sequentes affectum non iudicium racionis, beneficia curata suis nepotibus et familiaribus conferunt simpplicibus et ydiotis, qui nesciunt adhuc curare se ipsos. Et est hoc mirabile, quod multi tales propter deffectum morum et sciencie in bonis suis temporalibus debuissent habere curatores, et nichilominus non solum in ruribus vel castellis, set eciam in villis et ciuitatibus ponuntur animarum rectores. Accidit eciam aliud mirabile, de quo alibi legitur (se refiere al afamado jurista Juan de ANDRÉs, en su obra Novella in Decretales Gregorii IX, in capitulo Grave nimis. De prebendis (X 3.5.29), siguiendo al Hostiense y a otros doctores\} quod multociens prelatus committit duo millia animarum cui non committeret duo pira. Item tales prelati solum de lana et lacte curantes primam computacionem, secundum beatum Bernardum, faciunt de redditibus episcopatus non de animabus curandis».

En el epílogo, fol. 109 r, vuelve sobre el tema, recogiendo en parte las mismas palabras. 
todo simples e idiotas, que no saben informar al pueblo a través de la penitencia y de la predicación ${ }^{65}$.

Por parte de los clérigos, constituye una gran temeridad aceptar la cura de almas sin antes haber estudiado durante dos o tres años teología y derecho canónico y civil; al menos, deberían tener algún conocimiento de la gramática ${ }^{66}$. Es decir, que en última instancia se conforma con que los clérigos curados sean buenos gramáticos.

Insistiendo en la responsabilidad de los prelados u obispos, hace una referencia particular a la situación en España. Acusa a los obispos hispanos de ordenar a iletrados y recuerda al respecto la constitución del legado cardenal de Sabina Guillermo Godin, en la que se dispone que no se confiera orden sagrada a quien no sepa, al menos, hablar correctamente ${ }^{67}$.

Reconoce, no obstante, que en determinadas circunstancias está justificado que clérigos simples, sin apenas estudios, gobiernen iglesias curadas: cuando no se hallan otros más idóneos. Pone el ejemplo de Galicia y Asturias, y el de muchas regiones de Italia, en las que es práctica habitual

6s fol. $61 \mathrm{v}$ : «Dicit tamen ibidem finaliter Hostiensis vnum notandum, quod via istorum tucior est quam quiesciencium deliciosorum diuitum et ociosorum, et ponit verba: diuiciis vti res est inimica saluti, etc. Et Hostiensis verum dicit forte tempore suo, et ita communiter est. Set hodie ita sunt peruersi aliqui rustici quod excedunt in malicia eciam in villis et ciuitatibus commorantes, quod surgit precipue ex delictis et negligencia prelatorum, qui conferunt ordines et beneficia curata clericis omnino simplicibus et ydiotis, qui ipsos nesciunt in penitencia et predicacionibus dirïgere et informare».

66 fol. VI v: «Cum ergo secundum beatum Gregorium ars arcium sit regimen animarum, qua temeritate qui, non dico per duos vel tres annos, set numquam studuerunt in medicina animarum, hoc est, in theologia, iure canonico et ciuili, ymmo nec scientes adhuc bene grammaticam, audent recipere curas animarum, cum anime longe preciosiores sint corporibus».

De forma similar, se expresa cuando trata de los abusos de los sacerdotes y demás clérigos, incluyendo a los religiosos, en fol. 20 v: «Vltra hec, quantum ad articulum quintum est sciendum quod excedunt grauissime sacerdotes et alii clerici siue religiosi qui se permittunt promoueri ad beneficia curata, non habentes aliquam scienciam adhuc grammaticam».

67 fol. 2 v: «Item peccant prelati, precipue in Yspania, ordinando eciam ad sacros ydiotas et penitus illiteratos; et tales prelati in Yspania suspensi sunt ipso iure per constitucionem domini sabinensis legati in partibus predictis, qua continetur quod nullus prelatus presumat ordinare aliquem ad ordinem sacrum nisi saltem sciat litteraliter loqui».

Las distintas ediciones de este concilio coinciden con el autor en la frase «nisi saltem litteraliter sciat loqui ». Sin embargo, en algún sínodo, quizá con mejor sentido, el adverbio litteraliter se cambia por latinaliter, en referencia evidente al conocimiento del latín.

Por otra parte, la situación a la que se refiere no es exclusiva de la Iglesia española, aunque el autor la señale como un ejemplo relevante. En otros pasajes universaliza este mal en el seno de la Iglesia; así en fol. 20 v: «... set quia isto morbo multi in ecclesia Dei laborant, et hoc est vnum super omnia mala que michi videntur sub sole, scilicet, quod simplices, indigni et ydiote assumantur ad regimen animarum...». 
que clérigos idiotas sean rectores de iglesias curadas, en cuanto aprenden de alguna manera a leer y cantar. La razón de fondo de que esto suceda en esos lugares, sigue diciéndonos el autor, está en la pobreza de los beneficios curados; quien gasta su patrimonio en estudiar durante largo tiempo no se conforma fácilmente con un beneficio curado de acaso diez florines. Pero, incluso, tales clérigos pueden estar razonablemente al frente de beneficios ricos, si se muestran hábiles en el estudio de libros en lengua vulgar, como es posible en España, donde hay unos grandes volúmenes que recopiló Martín Pérez precisamente para los clérigos curados (se refiere, evidentemente, al Libro de las confesiones); también hay otros libros a mano en otras diócesis, como el Speculum Ecclesiae (de Hugo de Saint Cher, + 1264 ) y el Manipulus curatorum (de Guido de Monte Roterio). El amanuense del Speculum, en nota al margen derecho, añade a los tres citados el del propio autor del libro que copia: «Vel sicut est iste quem in manibus habes». Por su parte, el autor considera novedosa su opinión y, como hace siempre en estos casos, la somete a la corrección de un juicio mejor ${ }^{68}$.

Esta anotación bibliográfica del autor, válida sobre todo para la obra en romance de Martín Pérez, se debe entender, no tanto como una justificación para el ejercicio de la cura de almas con escasez de conocimientos, sino más bien como una invitación a los clérigos curados de pocos saberes para que tengan dichos libros a la mano y los consulten en el ejercicio de su ministerio pastoral.

Como una aportación personal del autor a la problemática de la colación de beneficios, afirma que el conferir beneficios, sobre todo curados, a indignos, aunque sólo sea simonía mental, genera obligación de restituir o satisfacer de los daños ocasionados a las iglesias afectadas.

Aduce, en primer lugar, razones jurídicas y teológicas, y termina con un argumento empírico: la experiencia misma nos muestra cómo cuando las iglesias son regidas por clérigos indignos e idiotas, los fieles laicos se retraen de colaborar en fundaciones, dotaciones, construcción, manteni-

${ }^{68}$ fol. $21 \mathrm{r}$ : «Hec vera puto nisi forte esset racionabilis causa in contra, puta quia magis ydonei non reperiuntur, vt notat Hostiensis in symilibus, in Summa, titulo De prebendis, \& Illud autem, sub \& Cui conferenda; vt est videre in finibus Yspanie, in partibus Galleciarum et Asturiarum, et in multis locis in partibus Ytalie, vbi de consuetudine tales ydiote regunt ecclesias curatas ex quo sciunt aliqualiter legere et cantare, cum propter paupertatem benefficiorum non reperiuntur alii. Non enim facile qui expendit patrimonium suum per magna tempora in studio laborando, vult reccipere benefficium curatum forte decem florenorum. Et idem forte eciam in magnis benefficiis, si tales sunt habiles studendo in libris in vulgari, sicut in Yspania sunt libri magni in vulgari pro rectoribus et curatis, quos copilauit quidam Martinus Petri; et in multis aliis diocesibus, alii libri qui apellantur puta Speculum ecclesie vel Manipulus curatorum (aqui, previa señal, el amanuense introduce la nota aludida). Supradicta tamen quia aliquibus noua videbunt subicio correctioni melius intelligentis». 
miento, etc., lo que supone un perjuicio grave a esas iglesias, por lo que los obispos implicados están obligados a satisfacer de los daños, en el marco de una verdadera penitencia.

Como el autor entiende que lo expuesto constituye una novedad, somete su parecer al juicio de la autoridad eclesial y a la corrección de cualquier opinión mejor fundamentada.

Aprovecha, también, la ocasión para denunciar, una vez más, que este abuso o exceso está muy extendido en la Iglesia, siendo pocos los prelados que manifiestan tener conciencia del mismo ${ }^{69}$.

\section{NORMATIVA SINODAL}

La normativa sinodal acerca de la ciencia de los clérigos con cura de almas se puede resumir en dos postulados básicos:

1) La exigencia mínima, y suficiente en principio, de ciencia en el clérigo cura se concreta en saber leer, cantar (canto llano, música religiosa) y gramática (con relación prioritaria al latín en un primer momento) para poder entender lo que lee: el misal, el breviario y los demás libros propios del oficio clerical. Esta exigencia se resume con cierta frecuencia, significativamente, en la expresión "saber hablar en latín».

2) Deberá saber, además, la doctrina cristiana, al menos en su formulación más elemental; este conocimiento se concreta en saber cuántos y cuáles son los artículos de la fe, los mandamientos de la ley de Dios, los sacramentos, los pecados o vicios, las virtudes, etc.

Con ambos saberes se cubre la doble vertiente de la acción del clérigo cura: hacia Dios, o litúrgica, mediante la celebración de la misa y la recitación de las horas canónicas; hacia el hombre creyente, o pastoral, mediante la administración de los sacramentos y la enseñanza-predicación de la doctrina cristiana.

69 fol. 3 v: «Aduerte circa predicta quod tales sic conferentes beneficia indignis precipue curata, eciam si solum sit simonia mentalis, tenentur, vt credo, in foro penitencie satisfacere de dampnis... et si hoc verum est multe anime prelatorum sunt in periculo, cum pauci sint qui, ve credo, de hoc faciant conscienciam in foro penitencie, dico quo ad satisfactionem exteriorem. Set quia hoc nouum et mirum videtur, intendo hoc ad presens probare multiplici racione... Item adhuc probatur per experienciam, que est validissima probacio in iure, qua videmus ecclesias grauari per indignos ministros, nam seculares videntes per tales indignos et ydiotas ecclesias regi,qui eciam multa que sunt tacenda committunt, retrahuntur a fundacione, dotacione et fabrica ipsarum etc. Ergo sequitur quod tales prelati tenentur vt vere peniteant satisfacere ecclesiis sic dampnifficatis. Hec sicut et omnia alia subicio determinacioni sancte Ecclesie et correctioni cuiuscumque melius sencientis; permaxime quia non reperio expresse tactum per aliquem glosatorem». 
Los sínodos del primer periodo de las diócesis de Castilla y León y de Portugal, aquellos que se ocupan del tema de la ciencia clerical, recogen, ante todo, la exigencia mínima referida a la vertiente litúrgica del clérigo, el cual, como sors Domini que es, tiene por oficio primero atender al culto divino, y para cumplir con él debe saber latín, que es el idioma en el que están escritos los libros litúrgicos ${ }^{70}$.

En los sínodos de la provincia tarraconense se observa ya desde el primer momento la preocupación que luego, durante el segundo periodo, se irá haciendo cada vez más patente en todos los sínodos peninsulares: la atención, incluso preferente, que los clérigos curados deben prestar al pueblo creyente.

Constituyen buena prueba de ello la Summa septem sacramentorum de Pedro de Albalat en el sínodo de Barcelona de 1241, con difusión bastante rápida en varias diócesis' ${ }^{71}$; el directorio sacramental de Ramón Despont en el sínodo de Valencia de 129672; el resumen de la doctrina que el obispo Pere Roig incluye en el sínodo de Lérida de 130173; y los sínodos de Gerona, celebrado entre 1247 y 1253 , y de Barbastro (diócesis de HuescaJaca) de 1280, en los que se explicita la triple función del ministerio sacerdotal: «circa corpus Ecclesiae, circa seipsos y circa populum sibi commissum $" 74$.

Por otra parte, esa exigencia primera viene referida por los sínodos peninsulares de uno y otro periodo, no sólo al clérigo cura, sino a todos los clérigos en general, desde la tonsura; o, expresamente, a un tipo o grado de clérigo en concreto, según los casos: acólito, clérigo-monaguillo, clérigosacristán, beneficiado, subdiácono, ordenado «in sacris», clérigo parroquial (rector, abad, vicario).

Esta diferencia de receptores directos de las normas sinodales tiene una explicación lógica. En principio, todo clérigo, desde la misma tonsura, es decir, para ser clérigo de acuerdo con las normas canónicas, debe ser letrado o estar en camino de serlo; ahora bien, la normativa sinodal suele atender a situaciones más concretas y, conforme a ellas, los distintos sínodos aplican la norma general, haciéndola recaer sobre unos u otros.

Además, el término clérigo se utiliza a veces como equivalente a clérigo cura, y otras veces es preciso acudir al contexto para poder determinar a qué clérigos en concreto se refiere.

70 Lisboa 1248, c.4 (SH II, 298); indirectamente, Badajoz 1255, c.6 (SH V, 13)); Braga 1281, c.1 y c.4 (SH II, 11-12); Braga 1285, c.5 (SH II, 29); indirectamente, Santiago de Compostela 1289, c.12 (SH I, 275)); León 1303, cc.13 y 39 (SH III, 266 y 281).

71 Linehan 9-30.

72 Sanchis Sivera I, 123-142.

73 Villanueva XVI, 317-323.

74 Para Gerona, Noguer-Pons 102-106; para Barbastro, Buesa Conde 88-92. 
Abundando en la terminología, he observado que los sínodos nombran muy pocas veces a los clérigos regulares; cuando hablan de clérigos, sin otra especificación, y es lo normal, se refieren sólo a los seculares' ${ }^{75}$. De otra parte, para referirse a los clérigos regulares se suelen utilizar los términos «religiosi» o «fratres», «religiosos» o «frailes».

También se puede deducir del contexto, y con relativa facilidad, si la norma afecta a todos los clérigos o, específicamente, a los que tienen cura de almas; en ocasiones, la misma norma aclara que se dirige a todos en general y, en especial, a los curados.

Normalmente, clérigo curado debería equivaler a clérigo ordenado de presbítero, o sea, sacerdote, a quien se ha encomendado la cura espiritual de un conjunto de fieles; pero, de hecho, no siempre se da esta equivalencia, ya que no era raro que los beneficios curados se concedieran a clérigos no sacerdotes, los cuales debían hacerse ordenar de presbíteros en el plazo de un año, obligación que se incumplía con excesiva frecuencia, como se deduce de las llamadas a su observancia en los mismos sínodos ${ }^{76}$.

De hecho, con dispensa, cabía incluso la posibilidad de conceder un beneficio curado a un clérigo no mayor de catorce años, como recoge la Primera Partida ${ }^{77}$.

En cualquier caso, el clérigo curado no sacerdote debía ocuparse de que un clérigo de misa, un vicario, ejerciera por él las tareas sacerdotales.

Los sínodos del segundo periodo de Portugal y de Castilla y León van centrando progresivamente sus disposiciones en los clérigos curados, al tiempo que van ampliando, al menos formalmente, los contenidos de la ciencia clerical exigible.

Así, de una parte, observamos que los textos sinodales, o se dirigen ya

75 Braga 1281, c.4 (SH II, 11-12), y Braga 1285, c.5 (SH II, 29), en cambio, son un ejemplo de lo contrario; especifican el término «secularis», aunque no hay en las constituciones citadas referencia alguna a los clérigos regulares.

${ }^{76}$ Concilio III de Letrán (1179) c.3 (X 1.6.7); concilio II de Lyon (1274) c.13 (In VI 1.6.14); concilio de Vienne (1311-1312) c.5 (Clem. 1.6.2); Lobn 1288, c.16 (SH III, 258); Santiago de Compostela 1289, cc.7 y 8 (SH I, 274-275); Braga 1301, c.6 (SH II, 36); Orense, Constituciones antiguas, c.37 <del obispo Pedro González de Orozco, 1395-1408> (SH I, 121); Coria 1457-1458, c.37 (SH V, 144-145); Porto 1496, c.24 = Braga 1505, c.21 (SH II, 372 у 155-156); Badajoz 1501, c.4.6 (SH V, 53-54).

77 tít.5 ley 63: «Otrosi puede dispensar \{el obispo\} con el que ha catorze años, porque pueda auer Eglesia que aya cura de almas». El glosador matiza al margen: «Hodie tamen adempta est episcopis potestas dispensandi in aetate, quo ad ecclesias parrochiales. per ca.licet canon.de electio.lib.6» (In VI 1.6.14).

Entre las muchas dispensas del requisito de la edad, hay que destacar la concedida al infante Juan de Aragón. A los 11 años fue elegido para arzobispo de Tarragona, elección que el papa Juan XXII no confirmó, alegando su corta edad; pero, unos años después, era nombrado arzobispo de Toledo. 
directamente a los curados, o aclaran que la norma les afecta a ellos de modo principal; de otra parte, abundan ya los sínodos que incluyen en su normativa instrucciones relativamente amplias de lo que debe conocer y practicar un clérigo curado.

Se observa asimismo en esos sínodos que, aunque el «saber hablar en latín» (dígase lectura, canto y gramática) está siempre presente como exigencia tradicional, de fondo, va perdiendo la primacía en la normativa sinodal. Al clérigo curado se le empieza a exigir más de cara al pueblo, y el pueblo no sabe latín.

A este propósito, interesan más otros saberes también propios de los curados, como son los relativos a la administración de los sacramentos, la enseñanza de la doctrina cristiana, la normativa canónica transmitida por las constituciones legatinas, provinciales y sinodales, y la tenencia, intelección y manejo correcto de los libros a usar en la cura de almas, es decir, los sacramentales en general y los confesionales para la penitencia en particular.

Respecto de las constituciones sinodales es clara la progresión de la exigencia de tenerlas y custodiarlas, con el fin evidente de consultarlas y utilizarlas, o sea de cumplirlas. Es una exigencia que acompaña siempre, de modo natural e implícito, a los sínodos; pero en muchos se halla de forma explícita, con una norma ad boc $y$ con apoyo penal ${ }^{78}$.

Muchos sínodos del siglo XIV y la mayoría del XV se promulgan en lengua romance 79 ; también se hacen muy frecuentes los tratados de confesión, las instrucciones de la doctrina cristiana y otras obras del género escritas en romance durante los siglos XIV y $\mathrm{XV}^{80}$. Se deja, incluso, entrever una cierta resignación ante el hecho innegable de la ignorancia del latín por parte de los curados. En esta misma línea se debe entender la norma de que el cuaderno de la doctrina, lo tengan en latín o en romance o sólo en romance ${ }^{81}$.

${ }^{78} \mathrm{Al}$ calor de los sínodos, se generalizan durante este segundo periodo los libros sinodales, verdaderos manuales de teología para curados, y se elaboran varias compilaciones de sínodos, siempre con el fin de facilitar a los clérigos el conocimiento de la normativa diocesana.

79 También nos han llegado en romance, con las rúbricas en latín, algunos sínodos del siglo XIII, como los de León de 1267 ó 1262 y de 1288; pero no hay constancia de que el texto originario estuviera escrito asimismo en romance.

80 El Speculum alude significativamente a este hecho. Ver texto en la nota 68.

${ }^{81}$ El mandato del legado Guillermo en el concilio de Valladolid de 1322, c.2 (Tejada III, 481), es que tengan el cuaderno en latín y en romance: «Ut quilibet Rector Parochialis Ecclesiae in scriptis habeat in Latina, et vulgari lingua articulos Fidei, praecepta Decalogi, Sacramenta Ecclesiae, species vitiorum et virtutum». Los sínodos diocesanos recogen este mandato tal cual, o mostrando su preferencia por la lengua vulgar. Por ejemplo, Toledo 1323, c. $\langle 5\rangle$ (Sánchez Herrero 176): en romance o en latín; Palencia 1345, c.<2> (San 
El grado de conocimiento de los saberes exigidos es, debe ser, de un nivel intermedio; se sitúa entre aquellos que deben poseer un conocimiento explícito, abierto, razonado y profundo de la fe, como son el papa y los obispos, y los laicos, a quienes no corresponde un conocimiento abierto, sino sólo saber lo que les enseñan los clérigos y lo que cada cual puede aprender de forma tradicional, consuetudinaria, «ex doctrina maiorum et ritu Ecclesiae».

Los simples curados, junto a los demás sacerdotes y a los que desempeñan el oficio de enseñar, como son los predicadores, maestros y doctores, forman una categoría intermedia; a ellos corresponde un conocimiento abierto, explícito, solamente de lo que conviene a su oficio, o sea, de los artículos de la fe en cuanto a la substancia y de lo que pertenece a la cura de almas, que se traduce, a fin de cuentas, en la administración de los sacramentos y en la enseñanza-predicación de la doctrina cristiana ${ }^{82}$.

Así, pues, no se exige que los curados alcancen una comprensión en profundidad, personalizada, de lo que leen, hacen y predican o enseñan; basta con que lean, hagan y prediquen o enseñen bien, en el sentido de evitar equivocaciones e incorrecciones en la lectura y en los ritos o ceremonias; y en cuanto a la enseñanza, se trata básicamente de una simple trasmisión, dígase anuncio, promulgación, lectura pública, explanación sencilla, de una doctrina empaquetada en fórmulas, con exigencia de fidelidad, ante todo, y sin exigencia de capacidad para poder hacer consideraciones de fondo. Que digan lo que sepan, si saben decir algo por sí mismos ${ }^{83}$.

Martín 142): al menos en romance; Oviedo 1377, c.1 (SH III, 396): en romance; Burgos 1411, c.<3> (López Martínez 249): en latín o en romance; Burgos 1443, c.<l > (Lopez Martínez 318): en romance; Braga 1477, c.35 (SH II, 108-109): enseñen el Pater noster, el Ave Maria y el Credo en latín y en romance, y los mandamientos, los artículos de la fe, etc., solamente en romance; Orense, Constituciomes antiguas, c.96 <correspondiente al obispo Diego de Fonseca, 1470-1496> (SH I, 133): en latín o, al menos, en romance; Salamanca 1497, c.1 (SH IV, 354): en romance.

${ }^{82}$ Liber synodalis de Gonzalo de Alba, promulgado en el sínodo salmantino de 1410, c.10 (SH IV, 80-81):» Vnde triplex est gradus in ecclesia... Supremi, ut papa et episcopi, tenentur scire istos articulos explicite et causam et rationem reddere, et non solum hoc, set etiam contra hereticos defendere, et dispositiones ad credendum declarare et persuadere... Medii uero in Ecclesia sunt curati simplices et qui ex officio habent alios docere, ut predicatores et doctores. Et isti tenentur explicite scire quidquid pertinet ad officium suum, scilicet, ad articulos quantum ad substantiam eorum, et quidquid pertinet ad administrationem sacramentorum... Infimi et inferiores, ut populus communis, non tenentur explicite scire nisi quantum traditum est eis ex doctrina maiorum et ritu Ecclesie, qui neminem latet, nisi ob culpam suam ab hoc impediatur... moneant sacerdotes laicos ne circa Trinitatem uel articulos fidei seu sacramenta Ecclesie rationem querant, quomodo uel quare ita sit, et inhibeant eis ne de talibus disputent $»$.

${ }^{83}$ Leon 1303, c.32 (SH III, 276): «Item, stablecemos que cada domingo enna missa prediquen los rectores, se sobieren o se acaescier y algun frade; et se non sobieren fazer sermon, digan aquello que sobieren depoes del evangelio». 
Como excepción, en la compilación sinodal de Barcelona de 1354 se considera tarea de los curados el instruir a los fieles y el confundir a los herejes con razonamientos, siempre conforme a su capacidad y ciencia ${ }^{84}$.

Para constatar la idoneidad de los candidatos, se les sometía, se les debía someter, a un examen de idoneidad sobre tres aspectos: vida, costumbres y ciencia, según las normas canónicas ${ }^{85}$.

La responsabilidad de los exámenes recaía en el obispo, quien, normalmente, no satisfacía dicha responsabilidad por sí mismo. Su vicario o delegado, los arcedianos y los arciprestes en el ámbito de sus respectivas jurisdicciones, o examinadores nombrados ad boc, se encargaban de examinar y de presentar los candidatos aptos al obispo.

La superación del examen constituía, al menos en principio, una garantía suficientemente sólida de la posesión de los conocimientos mínimos requeridos por parte del interesado. Sin embargo, de hecho, con relativa frecuencia, tal suposición resultaba fallida, al no practicarse el examen en la forma y con la seriedad convenientes, como se aprecia en el desglose de la normativa sinodal.

Cada vez que los sínodos aluden a que no se admita a la tonsura o a las órdenes, a los beneficios simples o curados, a quienes no reúnan las cualidades debidas, se está haciendo referencia a que el candidato debe pasar una prueba, un examen de suficiencia.

Pero, además, en numerosos sínodos se contienen referencias explícitas a los diversos exámenes de idoneidad: para la tonsura y las órdenes en general, para el subdiaconado y el presbiterado, para la cura de almas, para la revisión de los ya clérigos simples o curados, etc.; y en algunos sínodos se dictan normas reguladoras suplementarias para el examen, con la finalidad de garantizar mejor su seriedad y eficacia ${ }^{86}$.

${ }^{84}$ c.46 (Hillgarth-Silano 110): «Exortentur sepe prebiteri... et in aliqua parte sermonis aliquando exponant populo fideliter simbolum fidei et eis fideliter de questionibus satisfaciant et eis diligenter inquirant articulos fidei et consulant de questionibus et racionibus sacre scripture pro posse et sciencia sua propter laicos instruendos et hereticos corruptores fidei confundendos». Es evidente la oposición de este texto con el del libro sinodal de Gonzalo de Alba transcrito en la nota 82.

${ }^{85}$ D. 24 c. 2 y 5; D.81 c. $4 ;$ X 1.6.7; X 1.6.44; X 1.13.15.

${ }^{86}$ Lisbaa 1248, c.4 (SH II, 298); Valencia 1258 (Sáenz de Aguirre 200-201 nn.147 y 149); Lobn 12676 1262, c.52 (SH III, 248); Loon 1303, c.13 (SH III, 266); Zaragoza 1338, c.2 (Ochoa 151-152); Pamplona 1346 (Pamplona fol. 24ra); Barcelona 1354, cc.38 y 130 (Hillgarth-Silano 109 y 153); Lisbaa 1403, c.2 (SH II, 320); Santiago de Compostela 1435, c.1 (SH I, 323); Valenfa do Minbo 1444, c.4 (SH II, 427); Evora 1467, c.un. (SH II, 219-220); A randa 1473 (concilio provincial toledano), c.3 nn.9-11 (Sánchez Herrero 285-286); Braga 1477, c.27 (SH II, 100-101); Toledo 1480, c.<15> (Sánchez Herrero 313); Tuy 1482, c.12 (SH I, 357) Porto 1496, cc.34 y 36 (SH II, 379-380 y 381-382) = Braga 1505, cc.32 y 34 (SH II, 164 y 166); Badajoz 1501, cc.5.1 y 6.1 (SH V, 56-57 y 58-59). 
Además de señalar orientaciones de principio, la normativa sinodal hace frente a una situación de hecho: la ignorancia de muchos clérigos, que no sólo no sabían latín, sino que eran poco menos que analfabetos.

La situación era, ciertamente, delicada; hasta el extremo de considerar razonable y necesario que la norma relativa a la obligación de los clérigos ignorantes de estudiar para vencer la ignorancia no se aplique a los veteranos, teniendo por tales a los mayores de treinta o cuarenta años, a los cuales se les consideraba incapacitados para aprender, precisamente por razón de la edad.

Cabe pensar que esta suposición legal tenía su fundamento en la convicción de que tales clérigos no se habían ejercitado antes, o apenas, en el estudio, por lo que sus facultades iniciales a este efecto habían quedado atrofiadas o, al menos, seriamente mermadas, en grado bastante como para no esperar de ellos un aprovechamiento que justificase mínimamente el esfuerzo a realizar.

Esta excepción de la edad se remonta a las disposiciones del legado Juan de Abbeville, tanto en Valladolid (1228) como en Lérida (1229) ${ }^{87}$, y se tiene en cuenta en varios sínodos ${ }^{88}$.

Bien entrado el siglo XVI, los sínodos de Tuy de 1526 y de Orense de 1543-1544 la incluyen en su normativa ${ }^{89}$.

La permanencia en vigor durante tanto tiempo de esta excepción, pensada en principio para una situación transitoria, constituye un testimonio indirecto, que se une a los muchos testimonios directos de los mismos sínodos, de la falta de observancia, y consiguiente poco efecto, de las disposiciones sinodales que se iban promulgando en las distintas diócesis.

Además, es un reconocimiento implícito, pero claro, de que el proble-

87 Textos citados en la nota 23.

88 Braga 1281, c.1 (SH II, 11): «Excemptis illis de quorum profectu propter etatem non est sperandum»; Braga 1285, c.5 (SH II, 29): "Exceptis illis de quorum profectu propter etatem non est sperandum, utpote in anno xox. constitutis»; Zaragoza 1328, c.30 (Ochoa 147): «Eis tantum exceptis de quorum profectu propter etatem vel nimiam hebetudinem intellectus nullatenus est sperandum»; Evora 1467, c.un. (SH II, 220): "Acerqua dos que fossem leterados ou velhos, os quaaes starom aa nossa determinaçom»; Braga 1477, c.27 (SH II, 100-101): «Os que non son velhos nen leterados... E o juizo das ydades, da velhice e da literadura e do contrairo reservamos pera nós»; Avila 1481, c.2.1.1 (MS Madrid BN 8876, fol. $40 \mathrm{v}-41 \mathrm{r}$ ): "Que fuere mayor de hedad de diez annos e menor de treynta e cinco annos que non sabe cantar nin construyr»; Guarda 1500, c.46 (SH II, 250): "Até edade de quarenta anos».

${ }^{89}$ T T y 1526, c.9 (SH I, 393): «Otrosy se mando que los clerigos de orden sacro que al presente estan hordenados, que no llegaren a la hedad de treynta años, que hestudien gramatica»; Orense 1543-1544, c.21.1 (SH I, 225): «...estatuymos y mandamos a todos los clerigos curas e beneficiados... que estan en hedad de treinta años abaxo... los que no son suficientes gramaticos se vayan a estudiar". 
ma de la ignorancia clerical no era simplemente ocasional o coyuntural, sino estructural; estaba arraigado profundamente en el sector clerical dedicado a la cura de almas, era un mal endémico.

Así, podemos entender mejor que los autores de obras destinadas a los clérigos curados traten a éstos, ya de entrada, como simples, ignorantes, rudos, de pocos alcances.

Si el término clérigo llegó a ser en un tiempo, concretamente en el siglo XII, equivalente de persona culta ${ }^{90}$, en los siglos XIII-XV el clero parroquial rompe esa equivalencia y señala, más bien, a personas de poca capacidad o, cuando menos, de escasa preparación intelectual.

La razón fundamental de esta situación endémica de ignorancia hay que buscarla, a mi entender, en la pobreza relativa de los beneficios curados.

La profesión de curado, si se llevaba bien, de acuerdo con las normas canónicas, era realmente muy esclava y poco agradecida desde un punto de vista material: a unas dotaciones económicas apenas suficientes, y, a veces, claramente insuficientes, se unía la obligación de residencia en el beneficio y el estar siempre activo, a disposición de los feligreses, para el bautismo, la eucaristía, las confesiones, las visitas a los enfermos, la extremaunción, el matrimonio, la enseñanza de la doctrina; además del rezo de las horas y las demás obligaciones con relación a Dios y a sí mismos.

El concilio IV de Letrán apunta también en esta dirección. Acusa a los patronos de iglesias parroquiales de algunas regiones de apropiarse de la mayor parte de los frutos de las iglesias, dejando para los curados una parte tan exigua que no les permitía atender a su sustento con dignidad; de ahí que en estas regiones apenas se encontrase un sacerdote parroquial medianamente instruido ${ }^{91}$.

El autor del Speculum no duda tampoco en achacar a la falta de atractivo de los beneficios curados, a la desigual relación entre la dotación económica y las responsabilidades asumidas, el hecho de que al frente de dichos beneficios estén clérigos ignorantes y sin otras posibilidades. Los listos aspiran a beneficios mejor dotados, con obligaciones más llevaderas o, simplemente, con más o mejores compensaciones materiales ${ }^{92}$.

90 Cf. H. Santiago Otero, Fe y cultura en la edad media, Madrid, 1988, p. 93: 'En el siglo XII, la enseñanza y los estudios son monopolio del clero. «Culto» o «instruido» son términos sinónimos de clérigo'.

${ }^{91}$ c.32 (García 75-76): «Extirpande consuetudinis uitium in quibusdam partibus inoleuit, quod scilicet patroni ecclesiarum parochialium et alie quedam persone, prouentus ipsarum sibi penitus uendicantes, prebyteris earundem seruitio deputatis relinquunt adeo exiguam portionem ut ex ea congrue nequeant sustentari... Vnde fit ut in hiis regionibus pene nullus inueniatur parochialis sacerdos qui uel modicam habeat peritiam litterarum».

92 Véase el texto transcrito en la nota 68. 
Por otra parte, la falta de medios para costearse los estudios de muchos candidatos a los beneficios curados provocaba que las exigencias canónicas de ciencia para concederlos se rebajaran aún más, de modo que tuvieran acceso a ellos incluso candidatos menos dotados.

En el sínodo compostelano de 1435 tenemos un testimonio claro en este sentido. El arzobispo Lope de Mendoza (1399-1445) se ve en la necesidad de rebajar el nivel de exigencia de los exámenes para la promoción a las órdenes sagradas y, concretamente, a los beneficios curados, por razones económicas. Los candidatos de que disponía eran pobres, no podían estudiar y no alcanzaban la ciencia exigida. Para no dejar a las iglesias parroquiales sin curados, determina que, en cuanto a ciencia, sólo se les exija "que sepan bien leer e cantar... en caso que non sepan gramatiqua»" 93

\section{Detalle glosado de la NORMativa SinOdal por AREAS GEOGRÁFICAS}

\section{A. Corona de Aragón}

Como hemos señalado anteriormente, la provincia eclesiástica tarraconense acogió con decisión a partir de 1239 las normas de reforma del legado Juan de Abeville. Sin embargo, sorprende que en los concilios y sínodos el tema de la ciencia clerical no ocupe un lugar preferencial y que en muchos ni siquiera se aluda al mismo.

\section{a) Concilios provinciales}

En dieciocho de veintidós concilios celebrados entre 1230 y 1324 $(81,81 \%)$, no se hace alusión expresa al nivel de los conocimientos exigidos a los clérigos por los cánones y recordados por el legado: concilios de 1230, $1239,1240,1242,1243,1244,1246,1247,1250,1253,1256,1261$, $1274,1283,1292,1294,1306,1324$. Es preciso anotar, no obstante, que en cuatro de éstos, $1239,1244,1253$ y 1256 , se hace referencia en bloque a las constituciones legatinas de 1229, intimando su vigencia: «Constitutiones venerabilis patris I. Sabinensis... precipimus inviolabiliter observari $^{94}$. Además, en otros dos, 1274 y 1292, también se recuerda y rati-

93 c.1 (SH I, 323). Véase el texto completo en la nota 159.

94 Concilio de 1239, primero de los de Pedro de Albalat, c.l (Pons Guri 37). En los de 1244,1253 y 1256 se deja constancia de ello, en términos parecidos, en el proemio, como marco en el que se encuadran las normas propias del concilio respectivo. Además, en el de 1244, quinto de Pedro de Albalat, se recuerda también el concilio IV de Letrán; y en los de 
fica expresamente la vigencia de las constituciones provinciales promulgadas por los arzobispos anteriores ${ }^{93}$.

El concilio de 1293 alude a la necesidad de poseer ciencia para ser elegido y promovido canónicamente, sin más explicitaciones al respecto, en un contexto de condena de elecciones y promociones simoniacas, al amparo del poder y no del mérito personal ${ }^{96}$.

Solamente los concilios de 1266, 1277 y 1318 dedican ex professo alguna constitución al problema de la ciencia clerical.

Benito de Rocabertí, en su tercer concilio, año 1266, después de recordar e intimar, en la constitución número uno, de una manera global, las disposiciones legatinas, las de sus predecesores y las suyas propias anteriores, determina en la constitución número seis (conforme al mandato del legado, aunque no lo indica) que en cada iglesia catedral se elijan, a juicio del obispo y del cabildo, dos clérigos idóneos para enviarlos a estudiar teología y derecho canónico; cuando estos dos hayan acabado los estudios y vuelvan a sus iglesias, se enviarán otros dos, y así sucesivamente.

Dichos clérigos percibirán íntegramente las rentas de sus beneficios y las distribuciones cotidianas mientras permanecen en el estudio, al igual que si residieran personalmente en sus iglesias ${ }^{97}$.

Bernardo Oliver, en su segundo concilio provincial, año 1277, en la constitución número dos, recoge la disposición del concilio de 1266, y la refuerza y amplía.

Dispone, de una parte, que si el obispo y el cabildo, en su iglesia catedral, no cumplieran dicha disposición en un plazo de seis meses, la propia sede arzobispal asumirá, por esa vez, la responsabilidad de la elección de los dos clérigos y de su envío al estudio; de otra parte, ordena que lo dispuesto para las iglesias catedrales se extienda a las iglesias conventuales con, al menos, diez o doce clérigos y un prelado al frente, incluyendo el traspaso de poderes en caso de negligencia del prelado inferior ${ }^{98}$.

Jimeno de Luna, en su primer concilio, año 1318, recoge la constitución anterior de Bernardo Oliver al pie de la letra ${ }^{99}$.

1253 y 1256, primero y segundo de Benito de Rocabertí, se alude a las constituciones de los papas Inocencio III e Inocencio IV, amén de las promulgadas en concilios provinciales anteriores (Pons Guri 57, $75-76$ y 80-81).

95 Tarragona 1274, proemio (Pons Guri 91): «... per omnia confirmamus omnes constitutiones factas per predecessores nostros»; Tarragona 1292, proemio (Pons Guri 103): «... per omnia confirmamus constitutiones factas per praedecessores nostros».

96 c.l (Pons Guri 110): «... ut hii tantum quibus morum honestas ac donum scientiae suffragantur absque simoniae suspitione alterius que pravitatis vicio ad ecclesiastica beneficia assumantur. Nonnulli vero...».

97 Pons Guri 87 y 89.

98 Pons Guri 97.

99 c.8 (Pons Guri 131-132). 
Juan de Aragón, en el Corpus de 1330, recoge también, con una redacción algo diferente, la disposición de que venimos hablando; pero con una variante importante relativa al privilegio de los estudiantes de percibir íntegramente el fruto de sus beneficios. Benito de Rocabertí de forma explícita y, después de él, Bernardo Oliver y Jimeno de Luna tácitamente, al no indicar nada en contra, entendían que este privilegio estudiantil alcanzaba incluso a las distribuciones cotidianas ${ }^{100}$. Juan de Aragón, en el concilio de 1330 las excluye expresa y concluyentemente ${ }^{101}$.

El Corpus recoge también la norma canónica relativa al mínimo exigible para poder ser promovido a órdenes sacras: ser gramático, o sea, saber hablar bien en latín ${ }^{102}$.

Nada se dice acerca del lugar, modo y tiempo del aprendizaje. Parece dar por supuesto que estaba al alcance de cualquiera, lo cual, a su vez, significaría que había suficiencia de escuelas y maestros de gramática; claro es que sin otras pruebas, sin pruebas fehacientes, nos quedamos en simples hipótesis.

No hay, tampoco, alusión a la edad canónica; lo cual podría interpretarse en el sentido de que la edad era considerada como un requisito de menor importancia, siempre que se reunieran los otros dos: honestidad y ciencia. Un hecho, que afecta al autor principal del Corpus, facilita esta interpretación; Juan de Aragón había roto todos los esquemas canónicos respecto a la edad, como hemos anotado anteriormente ${ }^{103}$.

\section{b) Sínodos diocesanos}

En cuanto a los sínodos, de entre los que he podido consultar, son también pocos los que afrontan el tema; y apenas hay en ellos denuncias direc-

100 Concilio de 1266, c.6 (Pons Guri 89): «Quibus in predicto studio existentibus omnes proventus benefficiorum suorum et cotidianas distributiones integre sine diminutione aliqua dari mandamus ac si personaliter in ecclesiis residerent».

101 Corpus de 1330, c.68 (Pons Guri 180): «Persona vero predicta in dicto studio existens, omnia ea, cotidianis distributionibus dumtaxat exceptis, percipiat que percipe $<r e>n t s i$ in eisdem ecclesiis personaliter residerent $*$.

102 c.76 (Pons Guri 184): «Quia illi sunt ad honores ecclesiasticos promovendi qui moribus et scientia pollere noscuntur, statuimus prohibentes ne ad sacros ordines promoveantur qui (nisi en otros manuscritos) persone que gramaticam sciant seu latinis verbis loqui valeant competenter. Illi vero ad quos, ratione dignitatum vel personatam (personatuum en otros manuscritos\} quos obtinent, competit examinare clericos et ad ordines presentare (este párrafo, evidentemente, está incompleto en los códicas utilizados por Pons Guri). Potestatem autem dispensandi super hiis ex causa, et quatenus a iure permittitur, per hoc non intendimus episcopis interdictam».

103 En la nota 77. 
tas de la falta de conocimientos de los rectores de iglesias, ni de los clérigos en general; si acaso, insinuaciones indirectas en algunos. Se limitan a imponer la norma establecida por el legado Juan de Abbeville en el concilio de Lérida de 1229.

\section{1) Barcelona}

En el sínodo de 1241, convocado sede vacante por Pedro de Albalat, a la sazón arzobispo de Tarragona, se acuerda, como medida general, la observancia de las constituciones de 1229.

A continuación, el arzobispo recuerda lo establecido por él mismo en los concilios provinciales de Tarragona (1239) y de Valencia (1240) y, como primera medida específica, ordena que no se promueva a nadie al acolitado sin que sepa expresarse en latín ${ }^{104}$. Se trata de una disposición puntual, sin un desarrollo ulterior, como, por lo demás, suele suceder con una buena parte de las normas relativas al tema.

Junto a otras varias constituciones de carácter puntual como la indicada, Pedro de Albalat aprovechó la ocasión para promulgar su Liber synodalis, una breve Summa de los sacramentos para uso de los clérigos con cura de almas ${ }^{105}$.

Pedro de Centelles, en su primer sínodo como obispo de Barcelona (1243-1252), manda observar las constituciones legatinas de 1229 y las tarraconenses, citando expresamente al concilio de Valencia de 1240 y de modo genérico a los otros.

En alusión preferente al contenido de la Summa, precisa que todos los clérigos parroquiales deberán poner dichas constituciones por escrito y estudiarlas con esmero para saber administrar los sacramentos. El plazo ad quem para tenerlas por escrito queda fijado en la fiesta de san Juan (24 de junio). La desobediencia conlleva la suspensión del beneficio y la excomunión ${ }^{106}$.

104 Linehan 16: «Anno domini millesimo ccxli, die Sancti Luche, nos Petrus... ad preces capituli Barchinonensis, vacante sede, mandamus constitutiones venrabilis Sabinensis bone memorie, apostolice sedis legati, inviolabiliter observari editas in concilio Illerdensi... Ad memoriam nichilominus reducentes illa capitula que per nos in Tarrachone et Valencie provincialibus consiliis fuere statuta; districte mandantes quod ad acolitatum nullus promoveatur ordinem nisi loqui sciat verbis latinisw.

105 La importancia de esta Summa y de la acción reformadora de Pedro de Albalat la pone de relieve Linehan en el estudio previo a la edición de la misma, pp. 9-15, y en su obra La Iglesia española y el Papado en el siglo XIII. Edición española, revisada y puesta al día por el autor; traducción castellana de P. Borges, Salamanca, 1975, passim, especialmente el capítulo IV: Pedro de Albalat y la reforma de su provincia, pp. 49-73.

106 Prólogo (Villanueva XVII, 341): «Nos Petrus Dei gratia Barchinonensis Episcopus 
En su segundo sínodo, celebrado en noviembre de 1244 , recuerda la pena en la que han incurrido ipso iure los que en la fecha fijada no disponían de ellas ${ }^{107}$.

Ferrer de Abella, obispo de Barcelona entre 1334 y 1345, en el sínodo de 1339, constitución número 3, dispone que todo sacerdote, curado o no, tenga y sepa en el plazo de un año el tratado de la doctrina cristiana compuesto por Juan de Aragón. La inobservancia se castiga, "ultra penam iuris", con una multa de cien sueldos, que se destinarán a ornamentos de la iglesia a la que pertenezca el negligente ${ }^{108}$.

La compilación sinodal de Barcelona, elaborada en 1354 bajo la autoridad de Francisco Rufach, vicario general del obispo Miguel de Ricomá (1346-1361), contiene una normativa muy completa sobre el tema de la ciencia clerical y su proyección pastoral, recogiendo y superando todo lo dispuesto anteriormente al respecto. Haciendo un recorrido breve, destacamos las disposiciones siguientes.

En la constitución número 3 , como primera medida, se intima la observancia de las normas legatinas de 1229.

Luego, en la constitución número 4, asume las disposiciones de Pedro de Albalat dadas en los concilios provinciales de Tarragona y Valencia sobre

residentes in synodo in anno Domini M.CC.XLIII. kals. martii districte... ac sub poena excommunicationis... mandamus quatinus omnes clerici dioc<esis > Barchinon<ensis > in parrochialibus ecclesiis residentes, constitutiones venerabilis Patris $\mathrm{J}$. quondam Sabinen<sis> Episcopi, Apostolicae Sedis Legati, statuta etiam seu constitutiones quas Dominus Terrachon. in Valentino concilio vel aliis postmodum promulgavit conscribi faciant diligenter ac in eis intente studeant ut per eruditionem earum discant, qualiter in sacramentis ecclesiasticis et aliis quae continentur ibidem, oporteat se habere... Et quoniam de hiis quae promulgata sunt, eis multotiens est injunctum, nec quidquam adhuc observatum, statuimus ut quemcumque ex ipsis clericis usque ad festum Sancti Johannis prout ibi tradiderimus scribi non fecerit, nisi sit justo impedimento detentus, ex tunc beneficio quod habet noverit se suspensum». Cf. Sanabre 12-13.

Nótese en el texto citado la alusión genérica al incumplimiento global de la normativa eclesiástica: nec quidquam adbuc observatum.

107 c. $<20>$ (Villanueva XVII, 349): «Qui non habent constitutiones D. Sabinensis et D. Tarracon<ensis> Archiepiscopi in anno Domini M.CCXLIII. in festo Sancti Johannis Baptistae talis est: quod sunt suspensi a suis beneficiis ipso iure». Cf. Sanabre 13.

${ }^{108}$ Bajet i Royo 280: «Item quod quilibet sacerdos presbiter, cui sit uel non sit cura animarum comissa, habeat infra annum, et teneatur habere et scire tractatum quem dominus Johannes, bone memorie Patriarcha Alexandrinus et administrator ecclesie Tarrachonensis, composuit super articulis fidei, Xem preceptis et sacramentis ecclesie, que sunt fundamenta ecclesiastice dispcipline. Et qui negligens in hiis repertus fuerit, ultra penam iuris, penam centum solidorum incurrat, in ornamentis ecclesie, cuius rector uel administrator fuerit, conuertendam».

Sobre la influencia de este tratado de Juan de Aragón, véase mi artículo citado en la nota 63, Derecho canónico..., pp. 603-605, con la bibliografía que en él se ofrece. 
la materia: nadie será promovido al orden del subdiaconado sin saber hablar latín y los ya promovidos, y que no sepan hablar latín, dedicarán dos años continuos a su aprendizaje, bajo la pena de no percibir los frutos de sus beneficios; en el caso de no ser beneficiados, el castigo consistirá en una multa de 50 sueldos, permaneciendo firme la obligación de aprender. Los años de estudio comenzarán a computarse a partir de la fiesta de Navidad próxima venidera ${ }^{109}$.

Sobre la necesidad de saber latín insiste nuevamente, en la constitución número 42, al tratar del sacramento del orden; ahora de forma escueta ${ }^{110}$.

En la constitución número 19 se les exige a los sacerdotes parroquiales que tengan el manual de los sacramentos, conforme al uso y costumbre de la iglesia catedral ${ }^{111}$.

En la constitución número 118 se obliga a cualquier sacerdote, sea curado o no, a que tenga y aprenda en el plazo de un año el tratado de Juan de Aragón, bajo la multa de cien sueldos, *ultra penam iuris» ${ }^{112}$.

Tendrán, además, en el plazo de un año, las constituciones sinodales de Barcelona, es decir, la propia compilación de 1354 , y las provinciales, bajo la pena de cien sueldos, a repartir entre la catedral de Barcelona (el 50\%), el denunciante (un $25 \%$ ) y el obispo (otro $25 \%$ ).

Mediante esta pena pecuniaria se intenta dar mayor fuerza a la norma, dada la nula eficacia de normas anteriores en este sentido; se lamenta de que eran mayoría («quamplurimi») los que no las tenían y, lo que es más grave, ni siquiera sabían de su existencia; queja frecuente en los sínodos ${ }^{113}$.

109 c.3 (Hillgarth-Silano 97-98): «... mandamus constituciones uenerabilis patris Johannis, bone memorie apostolice sedis legati, inuiolabiliter obseruari editas in concilio Ilerdensi»; c.4: «Ad memoriam nichilominus illa reducentes que per dominum Petrum, miseracione diuina Tarrachonensem archiepiscopum, in Tarrachone et Valencie prouincialibus conciliis fuere statuta, districte mandamus quod ad subdiaconatus ordinem nullus promoueatur nisi loqui sciat latinis uerbis, quod addiscant per duos annos continuos, alias quod sint suspensi a fructibus beneficiorum suorum conuertendis in utilitatem beneficiorum suorum. Non beneficiati penam quinquaginta solidorum incurrant et penis solutis ad predicta etiam teneantur. Qui quidem anni incipiant a festo Natiuitatis Domini proxime uenienti et non antex.

110 Hillharth-Silano 109: «Item, dicimus quod nullus presentetur ad sacrum ordinem nisi sciat loqui latinis verbis competenter, et ut possint habere doctorum copiam, statutum est quod semper in cathedrali ecclesia detur porcio magistrow.

${ }^{111}$ Hillgarth-Silano 104: «Item, dicimus quod sacerdotes parrochiales omnes librum habeant in quo continetur ordo extreme unctionis, cathecuminorum, baptismi et huiusmodi, qui dicitur manualis uel ordinarium ecclesie secundum usum et morem qui obseruatur in ecclesia maiorix.

112 Esta parte está tomada de la constitución número 3 de las sinodales de Ferrer de Abella. Véase el texto en la nota 108.

${ }^{113}$ Hillgarth-Silano 156-157: «Experiencia rerum... nos docuit quod rectores... sunt ac 
En dos constituciones de la compilación se alude al examen que deben superar los clérigos.

En primer lugar, en la constitución número 38 se dispone que los ordenandos se examinarán ante los arcedianos «de vita, moribus et scientia» en las témporas ${ }^{114}$.

Por otra parte, en la constitución número 130 , se manda a los sacerdotes recién ordenados que no celebren la primera misa hasta ser examinados sobre el «canon» por el obispo o su vicario, bajo multa de cien sueldos ${ }^{115}$.

Por último, hay que señalar que la tarea asignada a los curados en cuanto a la enseñanza-predicación no se limita a una exposición rutinaria de la doctrina cristiana, como en la generalidad de los sínodos, sino que les compete también el explicar y razonar la fe para instrucción de los cristianos y confusión de los herejes ${ }^{116}$.

\section{2) Valencia}

Andrés de Albalat, obispo de Valencia (1248-1276) y hermano de Pedro, incluye la Summa de éste en el sínodo que celebró en octubre de $1258^{117}$.

En este mismo sínodo, Andrés de Albalat exige que los candidatos a

fuerunt quam plurimi negligentes adeo quod nedum non seruabant illas, immo quod grauius est penitus ignorabant ... precipimus... quatinus has nostras constituciones necnon et constituciones prouincie Tarrachone integraliter fieri faciant et habeant hinc ad unum annum... sub pena centum solidorum... cuius medietas operi ecclesie Barchinone, tercia uero denunciatori et alia tercia reuerendo domino Barchinonensi episcopon.

114 Hilgarth-Silano 109: «Item... quarta feria quatuor temporum omnes ordinandi archidiaconis transmittantur ut tam de uita quam de moribus quam de sciencia possit fieri scrutinium diligenter, utrum cantent uel legant uel sint legitimi uel loqui sciant latinis verbis, sic quod cum diligencia sint examinati et probati die Veneris qualiter in domo Domini debeant conuersariw.

115 Hilgarth-Silano 153: «Item, ordinamus et statuimus quod nullus decetero presbiter celebret primam missam donec per dominum episcopum uel eius uicarium in canone misse fuerit examinatus, quod si fecerit penam centum solidorum se nouerit incurrisse».

116 Véase el texto citado en la nota 84.

117 Sáenz de Aguirre 197: «Anno Domini 1258. Feria tertia, post festum Sancti Lucae. Nos frater Andreas... fieri mandamus, de tractatu septem Sacramentorum edito per Venerabilem Archiepiscopum praedecessorem Domini (por: patrem dominum) P<etrum>» \{continúa el tratado de los siete sacramentos\}.

En el sínodo de 1260 Andrés de Albalat vuelve a intimar a sus clérigos parroquiales la obligación de tener el Tratado de los sacramentos de su hermano Pedro: «Item statuimus, quo usque ad festum proximum Nativitatis Domini quilibet Clericus Parochialis habeat tractatum Sacramentorum, quem dominus $\mathrm{P}$ <etrus $>$ bonae memoriae Tarrachonensis Archiepiscopus edidit» (Ibid. 206, n.177).

Cf. Linehan 12, nota 20; Sanchis Sivera I, 141-142. 
órdenes se presenten a los arcedianos para ser examinados «tam de vita, quam de moribus, quam de scientia... utrum cantent, vel legant, vel loqui sciant Latinis verbis», es decir, la exigencia mínima canónica, en la que insiste luego: «Item dicimus quod nullus praesentetur ad quartum gradum, nisi loqui sciat Latinis verbis; et ut possint habere Doctorum copiam, statutum est, quod semper in Cathedralibus Ecclesiis detur portio Magistro Gramaticae»" ${ }^{118}$.

Su preocupación pastoral se observa asimismo en otras normas del sínodo mencionado de 1258 referentes a la obligación de los curados de enseñar las oraciones típicas del cristiano y exponer el símbolo de la fe en alguna parte del sermón, haciéndose eco, nuevamente, de lo ordenado en el sínodo barcelonés de $1241^{119}$.

Años después, y pese a los esfuerzos de Andrés de Albalat, buena parte del pueblo de la ciudad y diócesis de Valencia ignoraba el pater noster, y eran muy pocos los que sabían el credo in Deum, según se reconoce en el sínodo de 1273, séptimo y último de los celebrados por Andrés de Albalat ${ }^{120}$.

Ramón Despont, obispo de Valencia (1288-1312), en el sínodo que celebró el año 1296, promulga un «directorio sacramental» para uso de los curados, los cuales deberán tenerlo consigo en el plazo de un mes, bajo pena de veinte sueldos, que se aplicarán a la fábrica de la iglesia ${ }^{121}$.

Es evidente que Ramón Despont no conocía la Summa de Pedro; y, desde luego, tampoco conocía el sínodo de 1258, en el que dicha Summa estaba preceptuada e incluida.

Solamente así se entiende que el obispo Ramón Despont pueda aseverar de forma taxativa que en las constituciones sinodales valentinas no se había establecido nada hasta entonces acerca de los sacramentos, y que por esta razón él inserta algunas cosas en las suyas ${ }^{122}$.

118 Sáenz de Aguirre 200-201, nn. 147 y 149. Ambas normas se recogen, casi ad pedem litterae, en la compilación sinodal de la diócesis de Barcelona de 1354. Véanse los textos transcritos en las notas 114 y 110 respectivamente.

119 Ibid. 201-202, nn. 150 y 155 .

120 Sáenz de Aguirre 209, n. 206: «Item quia intelleximus, quod multi sunt in nostra Civitate et Dioecesi, qui ignorant Orationem dominicam, scilicet, Pater noster; seu ipsam perfecte non sciunt; et sunt paucissimi, qui sciant Credo in Deum...».

121 Prólogo (Sanchis Sivera II, 123): "Anno Domini MCCXCVI, decimo quarto kalendas octobris, Nos Raymundus... sacra synodo approbante, tractatum sacramentorum edidimus... Volentes et mandantes quod quilibet rector vel vicarius perpetuus tam tractatum praedictum, quam etiam constitutiones praemissas habeat in ecclesia sua infra mensem, ut iuvante Domino Jesu Christo cum ipsis se possint regere, et animabus gregis comissi iuste valeant providere. Quicumque vero infra dictum mensem ipsa non habuerint, penam viginti solidorum incurrant, operi ecclesiae Valentinae applicandam».

122 c.1 (Sanchis Sivera II, 123): «Idcirco cum de sacramentis ecclesiasticis in constitutionibus synodalibus ecclesiae Valentinae nihil fuerit constitutum... Nos Raymundus, mise- 
Resulta sorprendente este desconocimiento, si tenemos en cuenta que entre Andrés de Albalat (1248-1276) y Ramón Despont (1288-1312) sólo mediaban los diez años de pontificado de Yazperto de Botonach (12781287).

Sin entrar en ulteriores disquisiciones, me parece que del hecho se puede deducir que la Summa de Albalat era ya poco menos que letra muerta en la diócesis valentina.

\section{3) Calaborra-La Calzada}

En los sínodos de 1240 y 1260 , celebrados ambos en Logroño por el obispo Jerónimo Aznar (1238-1263), hallamos sendas ordenanzas acerca de los estudios clericales, que, aunque no están bien estructuradas, reflejan muy claramente las normativas lateranense y legatina.

En la constitución número 31 del sínodo de 1240 se da libertad a los clérigos para que puedan ir a estudiar a escuelas generales, «así como a Bolonia, o a París, o a Tolosa, o a Calahorra», durante tres años, sin pérdida de sus rentas beneficiales.

Al cabo de este tiempo deben volver y si el obispo viere que han aprovechado en la adquisición de conocimientos, les permitirá seguir adelante en los estudios; pero si no hubieren aprovechado bien, se les obligará a quedarse.

Junto a esta disposición para los clérigos en general, queda a salvo, para los que quieran aprovechar en letras, «todo el derecho de aquellos que van a Teología, e de los otros que van de las eglesias cathedrales, que fueren a otras sentencias» ${ }^{123}$.

En la constitución número 12 del sínodo de 1260 se establece que en cada arcedianato se instituyan dos maestros de gramática dotados de ciencia suficiente "para leer», es decir, para enseñar, a juicio del obispo; se les dará un salario adecuado a determinar por el propio obispo, o por el arcediano, o por el arcipreste.

El cometido de estos maestros de gramática será el de enseñar el latín a los clérigos, de modo que éstos no tengan la excusa de «que non saben fablar latín o pronunciar».

ratione divina Valentinus episcopus, de sacramentis ecclesiasticis aliqua, licet pauca, inserere volumus in eisdem».

${ }^{123}$ Bujanda 124-125: «Mandamos que, a los clérigos que quisieren ir a escuelas generales, así como a Bolonia, o a París, o a Tolosa, o a Calahorra, e que les den su ración del añal por tres años, e a cabo de tres años, que tornen; e si viéremos Nos que bien aprovechó, darle hemos licencia de ir, e si non aprovechare bien, mandaremos que finque; empero salvo todo el derecho de aquellos que van a Teología, e de los otros que van de las eglesias cathedrales, que fueren a otras sentencias». 
Los clérigos que acudan a estas escuelas recibirán íntegramente su "añal »; y los arcedianos, o arciprestes en su caso, se ocuparán de que aprendan y de que las iglesias no queden disminuidas en su servicio ${ }^{124}$.

\section{4) Gerona}

En las constituciones sinodales de Berenguer de Castellbisbal (12451254), de fecha incierta entre 1247 y 1253 , no se trata de la ciencia que deben poseer los curados, sino que todo el interés se centra en la tarea pastoral que deben desarrollar, en una triple vertiente: hacia la Iglesia, hacia sí mismos y hacia su fieles ${ }^{125}$.

El sínodo parece dar por supuesto que los clérigos gerundenses reúnen los conocimientos adecuados; cuando menos, no los pone en duda, a pesar de que su fuente principal es el concilio de Lérida de 1229, en el que, como es sabido, se denuncia con cierta dureza la incultura del clero de Hispania.

El conjunto de disposiciones se caracteriza, como señalan $T$. Noguer y J.M. Pons, por su escaso contenido jurídico y por su carácter marcadamente pastoral.

Observan asimismo estos autores, remarcando la importancia del sínodo, que esta normativa la insertó en su compilación el obispo Arévalo de Zuazo (1598-1611) con la anotación marginal siguiente: «Haec constitutio fuit per tercentum annos continuos lecta in Synodo Dioecesana»" ${ }^{126}$.

En la colección de constituciones sinodales del obispo Arnau de Montrodon (1335-1348) hallamos varias disposiciones relativas, de una u otra forma, a los saberes clericales.

En la constitución número 13 se ordena que el clérigo veterano instru-

124 Bujanda 129: «Establecemos que en cada Arcidianado lean dos maestros de Gramática, en logares convenientes, e Nos, que sepamos si son suficientes para leer, e sea el su salario convenible, establecido por el Obispo, o por el Arcidiano, o por el Arcipreste, e los clérigos que pecharen salario, non den colecha al maestro, e los que fueren para aprender, constríngalos el Arcidiano, o el Arcipreste, que aprengan, e hayan sus raciones entegramente del añal, pero así que las eglesias non sean menguadas de su servicio adebdado; e así non podrán haber excusa, que non saben fablar latín, o pronunciar».

125 c.1 (Noguer-Pons 102-105): «Sacerdotes et clerici curam animarum habentes, debent circa tria esse solliciti et intenti, videlicet circa corpus Ecclesie, et circa seipsos, et circa populum sibi comissum. Circa Ecclesiam, septem debent attendere... Circa secundum, idest circa seipsos, quinque sunt attendenda, videlicet habitus, offitium, conversatio, predicatio (enseñanza, predicación, admonestaciones, sobre todo acerca del sacramento de la penitencia\} et administratio \{en torno a la administración de los sacramentos\} ... Circa tertium, idest circa subditos, debent esse vigiles et attenti, precipue ne eos in peccato publico sinant essew.

${ }^{126}$ Noguer-Pons 102. 
ya al sacerdote novel en la celebración de la misa y en la administración del bautismo y de los otros sacramentos, según la tradición eclesial ${ }^{127}$.

Se trata, en este caso, de una transmisión de conocimientos prácticos desarrollada, no en el ámbito escolar, sino de persona a persona, en el ejercicio de la labor parroquial.

En la constitución número 61 se establece la obligación de los rectores de iglesias de tener en su poder, en el plazo de un año, y a costa de las propias iglesias, la normativa sinodal actual y anterior, como medio del todo necesario para conocerla y poderla cumplir; la negligencia en este punto se pena con una multa de cincuenta sueldos barceloneses, que irán a parar a las arcas del obispo ${ }^{128}$.

En la constitución número 67 se contiene una breve instrucción cristiana, que el curado debe mostrar al pueblo en la predicación, con frecuencia, «quando ei videbitur expedire».

Dicha norma se basa en un argumento tradicional: si el pueblo no conoce la doctrina, es, principalmente, por culpa de la ignorancia de sus rectores $^{129}$.

En la compilación de sinodales mandada elaborar por el obispo Ennec de Valterra (1362-1369), que fue promulgada en el sínodo de 1368, constitución número 1 , se recogen, tal cual y como si se tratara de un todo, de una instrucción sacerdotal única, la sinodal de Berenguer de Castellbisbal relativa a la triple solicitud de los curados y el compendio de doctrina cristiana de Arnau de Montrodon, con la única diferencia de que lo que en

127 Noguer-Pons 124: Item quod quilibet clericus teneatur instruere et informare novitios presbiteros in sua ecclesia beneficia obtinentes in et super quibus verbis conficitur Corpus et Sanguis Ihesu Christi, et baptismus datur seu confertur, et que orationes ad predicta et alia sacramenta ecclesiastica conficienda et tradenda sunt necessaria, ac etiam oportuna, secundum formam Ecclesie super hiis traditam sive datam».

${ }^{128}$ Noguer-Pons 142: «Item cum parum esset constitutiones facere nisi servarentur, et servari non possent nisi scirentur, ideo statuimus quod omnes rectores ecclesiarum nostre diocesis infra annum a presenti Sinodo in antea computandum, habeant et habere teneantur in suis ecclesiis omnes et singulas constitutiones sinodales nostras et predecessores nostrorum, et quicumque in predictis necligens fuerit, incurrat penam quinquaginta solidorum Barchinone nostro erario applicandam. Et hec fieri volumus ad expensas operis ecclesiarum diocesis supradicte».

$129 \mathrm{La}$ instrucción contiene, en simple enunciado y por este orden, los mandamientos, los artículos de la fe (atendiendo a la doble modalidad de doce y catorce), los sacramentos, los dones del Espíritu Santo, los pecados y las obras de misericordia corporales. Luego, viene el colofón: «In predicta volumus quod sciat quilibet sacerdos, vel rector, seu vicarius ut super ipsis possit instruere populum sibi comissum in predicationibus, et hoc frequenter quando ei videbitur expedire, nam magna culpa est rectoris cuiuslibet quod parrochiani sui precepta legis et articulis Fidei ignorent; et ex hoc, est graviter corrigendum* (Noguer-Pons 144147). 
Arnau de Montrodon figura como colofón, sirve ahora de nexo de unión y de introducción al compendio; de otra parte este pequeño texto aparece aquí con una redacción mejorada ${ }^{130}$.

Asimismo, en la constitución número 11 de dicha compilación, se inserta otra de Arnau de Montrodon, concretamente la constitución número 13 , que se refiere a la formación en prácticas de los curas noveles por los veteranos $^{131}$.

\section{5) Lérida}

En el sínodo leridano celebrado por Raimundo Ciscar en torno al año 1240 se incluye un breve directorio de los sacramentos para los curados. Al final del mismo, después de tratar del sacramento de la extremaunción, relaciona los libros que deben tener a mano los sacerdotes parroquiales: «Librum quidem qui dicitur Manuale habeant singuli sacerdotes parrochiales ubi contineatur officium extremae unctionis, cathecismi et baptismi et huiusmodi. Habeant etiam psalmi poenitentiales et ordinarium et officiarium et consuetudines ecclesiae de horis dicendis secundum modum et usum qui observatur in ecclesia majori ${ }^{132}$.

Pere Roig, obispo de Lérida (1299-1308), en el sínodo celebrado el año 1301 , inserta una relación sucinta de la doctrina cristiana que deben conocer los sacerdotes.

Se trata, evidentemente, de una instrucción cristiana que iba a tener, si no tenía ya, una amplia difusión en las diócesis de la provincia eclesiástica tarraconense. Cuando menos, es la misma que adoptan para la diócesis de Gerona Arnau de Montrodon (1335-1348) y Ennec de Valterra (13621369).

Se echa en falta en esa instrucción la mención a las virtudes y a las obras de misercordia espirituales; por otra parte, a falta de las virtudes, tiene la originalidad de contraponer a los pecados las obras de misercordia corporales $^{133}$.

130 Obsérvese, en efecto, la diferencia con el texto transcrito en la nota anterior: «Item debent sacerdotes scire decem precepta legis, articulos fidei, sacramenta Ecclesie, dona Sancti Spiritus, septem vitia idest peccata mortalia, et opere misericordie, ut possint instruere populum sibi commissum in predicationibus et confessionibus, nam magna culpa est rectoris cuiuslibet quod parrochiani sui predicta, presertim precepta legis, et articulos fidei ac mortalia peccata ignorent, et ex hoc est graviter corrigendus» (Noguer-Pons 186).

131 Es copia literal, con una variante puramente formal, que no cambia, ni mínimamente, el sentido del texto. Donde el obispo Arnau de Montrodon ponía «beneficia obtinentes», Ennec de Valterra pone «beneficiatos». Véase el texto completo en la nota 127.

132 Villanueva XVI, 297-302.

133 c. $<4>$ (Villanueva XVI 319-321): «Ista quae secuntur tenetur scire quilibet sacer- 


\section{6) Huesca-Jaca}

El obispo Domingo Sola (1253-1269), en un sínodo del que no conocemos con exactitud el lugar y la fecha, compendia, según se afirma en el proemio, los cánones de Letrán IV, las constituciones legatinas de 1229, los decretos de los concilios provinciales y las normas sinodales de sus predecesores $^{134}$.

Concretamente, en la constitución número 2 , «da normas sobre la presentación de los ordenandos al obispo y su examen, sobre las condiciones que deben reunir los aspirantes al presbiterado y sobre la intervención de los arciprestes" ${ }^{135}$.

En la constitución número 30 dispone que "haya un magister in gramatica en las catedrales de Huesca y Jaca, que los beneficiados de las iglesias parroquiales sean obligados a aprender de los maestros, si los tienen, y que ad quartum gradum suscipiendum sea necesario saber hablar latín» ${ }^{136}$.

Del sínodo celebrado por Jaime Sarroca el año 1280, interesan los dos primeras constituciones.

La primera se refiere a la triple solicitud de los curados circa Corpus Ecclesiae, circa seipsos y circa subditos ${ }^{137}$.

La segunda establece que no se promueva a un beneficio a quien no haya sido declarado idóneo por el obispo ${ }^{138}$.

dos ut sciat docere populum sibi comissum. In primis tenetur scire decem precepta legis quae sunt haec... articulos fidei...septem sunt sacramenta ecclesiae... septem sunt dona Spiritus sancti... septem sunt peccata mortalia... septem sunt opera misericordiae cum quibus debet homo contra peccata mortalia se munire, scilicet: Visitare infirmos... Ista predicta volumus quod sciat quilibet rector vel vicarius, et (mejor ut\} super ipsis possit instruere populum sibi comissum in predicationibus et hoc frequenter, quando ei videbitur expedire».

El texto es, prácticamente, idéntico en los tres casos, con variantes de menor importancia. Por ejemplo, en las versiones de Arnau y de Ennec no se explicita que las obras de misericordia (corporales) sean la coraza con la que el hombre debe protegerse contra los pecados mortales, pero esto es, simplemente, porque en estas versiones se da sólo el enunciado, sin comentario alguno. Por lo demás, el contenido es el mismo y los seis apartados de que consta la instrucción están redactados en el mismo orden.

134 Buesa Conde 78.

135 No dispongo del texto; sólo del enunciado de los títulos y del resumen de su contenido, tal como aparecen en Buesa Conde 79-87.

136 Buesa Conde 83. Vale lo indicado en la nota anterior.

137 Buesa Conde 89. No he podido tener a la vista el texto en cuestión, pero es de suponer que coincida, al menos básicamente, con el de los sínodos de Gerona de Berenguer de Castellbisbal (1247-1253) y de Ennec de Valterra (1368). Véase un resumen del texto aludido en la nota 125.

${ }^{138}$ Buesa Conde 89. 


\section{7) Zaragoza}

Pedro López de Luna, primer arzobispo de Zaragoza (1317-1345), en sus dos sínodos, años 1328 y 1338, a tenor de las disposiciones lateranenses y legatinas, dispone varias normas sobre los estudios de los clérigos.

En el sínodo de 1328, constitución número 30, establece que en cada arcedianato, en el lugar que se estime adecuado, se instituyan escuelas de gramática para que puedan estudiar cuantos lo deseen. En cuanto a los beneficiados y a los que van a ser promovidos para iglesias parroquiales, que, disponiendo de maestro, rehúsen estudiar, se les obligará a ello hasta que sepan hablar latín, bajo la pena de la sustracción del beneficio.

Quedan exceptuados de la obligación de estudiar aquéllos de los que no cabe esperar aprovechamiento, sea debido a su edad o a su grave debilidad mental.

En cualquier caso, no se admitirá al quarto grado, o sea, al acolitado, a quienes no sepan hablar latín ${ }^{139}$.

Aunque el latín va perdiendo fuerza en el ámbito pastoral del quehacer clerical, sigue significando mucho en el ámbito cultual. Para el pueblo se hace necesario emplear la lengua vulgar; para Dios, el lenguaje sigue siendo el latín.

El sínodo de 1338 complementa en algunos puntos al de 1328.

La constitución número 1 exige saber leer y cantar con soltura para ser admitido a la clericatura ${ }^{140}$.

En la constitución número 2 se determina, entre otras varias cosas, que los examinadores de los ordenandos no deben admitir a las órdenes sagradas a los que no sepan desempeñarse bien en la lectura y en la gramática ${ }^{141}$.

139 Ochoo 147: «Statuimus ut in quolibet archidiaconatu Nostre diocesis, certis locis ad hoc idoneis, schole in grammatica habeantur, ne volentibus in scientia profiscere proficiendi opportunitas adimatur. Omnes quoque beneficiati et ad ecclesianum parrochialium titulos promovendi, qui habentes magistrum adiscere contempserint, eis tantum exceptis de quorum profectu propter etatem vel nimiam hebetudinem intellectus nullatenus est sperandum, per beneficiorum substractionem, quousque verbis latinis loqui sciverint, addiscere compellantur; ad quartum autem gradum suscipiendum nulli omnino, nisi latinis verbis loqui sciverint, admittantur".

Con relación a la edad, no se precisa en este sínodo a partir de qué años concretamente se debe, o se puede, aplicar la excepción. Como he señalado anteriormente (notas 88 y 89), algunos sínodos fijan la edad de la vejez para el estudio en los 30, 35, 40 años; algún otro la deja expresamente a criterio del obispo; y algunos más no la precisan, dejando también indirectamente su determinación al buen juicio del obispo.

140 Ochoa 151: «Nemo, absque crismatione in fronte, ad primam tonsuram de cetero admittatur et nisi competenter saltim legere et cantare sciat ».

${ }^{141}$ Ochoa 152: «Quamvis clementina... Addicientes quod nullus, per examinatores ad ordines deputatos, recipiatur ad sacros ordines, nisi saltem in legendo et construendo se habuerit competentern. 
De la constitución número 13 se deduce que eran bastantes los curados que gozaban de licencia para no residir en su beneficio por razón de estudio o por otra causa.

El obispo, a la vista de que muchos de ellos se dedicaban a la vagancia o a negocios privados, por cuenta propia o ajena, decide revocar tales licencias e impone unas condiciones rígidas para gozar de ellas ${ }^{142}$.

Catorce años más tarde, el arzobispo Lope Fernández de Luna (13511382), en su primer sínodo, año 1352, a instancia unánime de los padres sinodales, atemperaba el rigor de la sinodal de su predecesor, respetando la parte sustantiva de la misma ${ }^{143}$.

\section{8) Pamplona ${ }^{144}$}

La compilación sinodal de Pamplona, elaborada por Fernando de Baquedano a instancias del sínodo de 1499 , recoge selectivamente para cada tema tratado las constituciones de sínodos anteriores, desde principios del siglo XIV, junto a las emanadas del citado sínodo de $1499^{145}$. Entre ellas, hay algunas que dicen relación al saber clerical.

El obispo Arnalt de Barbazán (1318-1355), cuyo episcopado es no sólo el más largo, sino también el más brillante del siglo $\mathrm{XIV}^{146}$, es el único que trata del tema directamente.

En el sínodo de 1330 recoge, a su modo, la clásica exigencia mínima, o

142 Ochoa 157: «Ceterum quia nonnulli rectores et alii beneficiati, studii vel alia causa legitima, ad certum tempus vel incertum a Nobis licentiam obtinentes, vagantur ut plurimum et ad alia privata sua vel aliorum negotia voluntarie se convertunt, ne de sui malitia reportent commodum, talium licentiam, etiam durante ipsius termino, revocamus. Que omnia in concedendis licentiis de cetero volumus observari».

143 c.2 (Ochoa 321-322): «Penam constitutionis synodalis que incipit: Priores, Archidiaconi etc., que beneficiatos a suis beneficiis certis temporibus absentes punit, quoad penam privationis beneficiorum eius rigorem temperantes, ad supplicationem totius Synodi dictam penam tollimus et levamus, in ceteris autem dicta constitutione cum suis penis in suo robore perdurante».

144 La diócesis de Pamplona fue sufragánea de Tarragona hasta 1318; luego, hasta 1574 lo fue de Zaragoza, con un paréntesis de treinta y cinco años, entre 1385 y 1420, periodo en el que fue diócesis exenta, es decir, sometida directamente a la Santa Sede.

${ }_{145}$ Pamplona fol. 4 ra: «Que quidem constitutiones fuerunt recollecte et posite per ordinem sub certis et propriis titulis et rubricis, ad instantiam huius sancte sinodi vltimo celebrate de mandato prefati domini Iohannis de Monterde vicarium generale per venerabilem virum dominum Fernandum de Vaquedano prothonotarium Nauarre et archipresbyterum de Ycarri dicte Pampilonensis diocesis et impresse per magistrum Arnaldum Guillermum de Brocario Pampilone etc. sub forma sequenti».

146 Cf. José Goñi Gaztambide, Los obispos de Pamplona del siglo XIV, «Príncipe de Viana», 23 (1962), p. 46. 
sea, que nadie en adelante sea promovido a las órdenes sagradas si no es un buen gramático ${ }^{147}$.

Anoto que en ese requisito de ser buen gramático no hay ya una alusión prioritaria al latín, pues se admite, y se tolera, que hay clérigos curados que no entienden bien la lengua latina. Por ello, precisamente, el obispo Arnalt de Barbazán, en el sínodo de 1354, promulga una instrucción sacramental bastante amplia, en lengua vulgar, para los curados que no saben bien latín ${ }^{148}$.

Tenemos aquí una prueba más de cómo la expresión "ser gramático» (in grammaticalibus instructus) fue cambiando y, en cierto sentido, ampliando, su significado.

En el siglo XIII equivalía, al menos de forma prioritaria, a saber latín, a dominar la gramática latina lo suficiente para expresarse en latín y entender bien su lectura; de ahí derivaba a significar, a veces, el conjunto de saberes del clérigo; pero ser gramático era, ante todo, saber latín.

Durante el siglo XIV, pero sin que me atreva a señalar una fecha concreta del inicio del cambio (quizá, el concilio legatino de 1322), que se realizó sin duda poco a poco y no por igual en todas partes, «ser gramático» va ampliando su significación, hasta llegar a equivaler, también, a ser instruido en la construcción gramatical de la lengua hablada por el pueblo, de la lengua vulgar o romance; incluso, se puede ser gramático y no saber bien latín.

147 Pamplona fol. 23 vb: «Scriptum etenim est: quod si cecus ceco ducatum prebeat ambo in foueam cadunt. Cecus enim reputari potest clericus qui quod legit non intelligit, vt habeat locum quod sapiens attestatur, legere et non intelligere negligere est. Ideo statuimus quod de cetero nullus subditorum nostrorum ad sacros ordines promoueatur, nisi in grammaticalibus it competenter instructus, immo penitus repellatur: vt possit de eo dici, scientiam repulisti, et ego te repellan: ne sacerdocio fungaris».

148 Ms Pamplona AC 7, fol. 1 ra - 13 vb. En el folio 1 ra-va expone las causas primera y final, origen y objetivo, de la Suma: «Arnalt por la gracia diuinal obispo de Pamplona... por que nos en estrecho juizio podamos rendir buena razon et cuenta del officio... et maguer aquellas personas a las quales es cometida et pertaynesce la cura de las animas deuen auer sciencia et sufficiencia... Empero nos por cierta sapiencia somos certificados que... los rectores... son negligentes... Por ende nos... porque los dichos rectores vicarios et capellanes sean plenamente instituidos et informados... auemos ordenado et deliberado fazer una breue suma et compilacion en lengua uulgar et manual porque los dichos rectores vicarios et capellanes algunos de los quales non saben bien latin puedan claramente entender los articulos en la dicha suma de suso escripta contenidos la qual queremos ser clamada suma de los sagramentes et de las cosas a la cura de las animas pertenescientes».

Esta Suma, completada en algunos puntos en el sínodo de 1499, se imprimí en Pamplona el año 1501 en la imprenta de Arnaldo Guillermo de Brocar, junto a las constituciones provinciales de Zaragoza, las sinodales de Pamplona, un tratado de Antonino de Florencia, los derechos del sello episcopal y las taxaciones de los beneficios. Cf. J. Goñi Gaztambide, o.c. 87-88, en referencia al sínodo de 1354. 
A los clérigos de misa se les sigue exigiendo conocer el latín suficiente para celebrar misa, rezar las horas, etc. Pero ya, esta expresión y esta exigencia (de saber latín), van perdiendo, en la literatura sinodal, ese sentido globalizante, total, de los saberes clericales, que anteriormente habían llegado a tener.

En el sínodo de 1346, Arnalt de Barbazán recuerda e intima el cumplimiento de lo establecido en el de 1330 sobre la exigencia de ser buen gramático para recibir órdenes sagradas, dado que algunos se obstinaban en su inobservancia, en referencia a los patronos y a los examinadores; sobre todo a éstos, cuya trangresión castiga con la excomunión ipso facto ${ }^{149}$.

El obispo Arnalt de Puyana (1310-1316), en el sínodo de 1313, hace una referencia al estudio como causa para ausentarse por largo tiempo de la iglesia en la que el clérigo ejerce la cura de almas, pero no alude al privilegio del estudiante de recibir los frutos de su beneficio como si residiera en él.

Simplemente, le interesa recordar que para ausentarse por ese motivo, o para peregrinar, es necesario pedir y obtener la licencia del obispo ${ }^{150}$.

Empero, el obispo Nicolás de Echavarri (1462-1469), en el sínodo de 1466, sí se hace eco del privilegio estudiantil y lo aplica a los alumnos y maestros del estudio de Pamplona, a pesar de que no tenía categoría de Estudio General, según se infiere del texto ${ }^{151}$.

\section{B. Galicia y Portugal}

La inclusión de las diócesis de Galicia y Portugal en un epígrafe común obedece al entreverado administrativo que les afecta durante varios siglos. Hasta el año 1393 las diócesis portuguesas de Evora, Idanha (Guarda), Lamego y Lisboa fueron sufragáneas de Santiago de Compostela, mientras que las diócesis gallegas de Lugo, Mondoñedo, Orense y Tuy lo eran de Braga.

149 Pamplona fol. 24 ra: «Peruersitatem iniquorum... refrenare cupientes precipiendo mandamus constitutionem per nos alias in sinodo de clericis competenter in grammaticalibus non instructis ad sacros ordines vel ad curam animarum non assumendis tam per promouendos quam per ad eorum examinationem deputatos inuiolabiliter obseruari. Si quis autem predictorum examinatorum predicte constitutionis trangressor extiterit excommunicationis sententiam incurrat ipso facto».

150 Pamplona fol. 4 rb: *Item statuimus vt nullus causa studii vel peregrinationis diutine ab ecclesia quam obtinet curam animarum habente se absentet, nisi prius a nobis petita licentia et obtenta».

151 Pamplona fol. 13 vb: «Item fuit statutum quod studentes in ciuitate Pampilonensis et preceptores in eadem gaudeant fructibus beneficiorum ac si residerent in studio generali dum tamen in eadem publice et continue legatur saltem de grammatica et logica». 


\section{a) Galicia}

Entre 1228 y 1322 encontramos algunos datos sobre la cultura clerical gallega en los sínodos de Santiago de Compostela de 1229, 1289 y 1313; sobre todo, en el de 1229, siendo arzobispo Bernardo II (1224-1237).

Vicente Beltrán de Heredia afirma que lo dispuesto en el sínodo de Bernardo II con relación a la formación intelectual del clero "refleja una situación bastante superior a la exigida por el Lateranense " ${ }^{152}$. Me parece una aseveración excesiva; en realidad, la disposición sinodal aludida, constitución número 1 del sínodo de 1229 , no especifica el grado de ciencia a exigir ni el contenido concreto de los estudios a realizar; podría, eso sí, estar en relación con una práctica anterior de selección de clérigos idóneos para el estudio, que se pretendería reglamentar mejor para evitar abusos e incumplimientos, como opina el mismo Vicente Beltrán de Heredia ${ }^{153}$.

Pero, aunque no haya una conexión expresamente reconocida de este sínodo con el lateranense IV ni con el legado papal Juan de Abbeville, "cuyos planes de reforma no afloran excesivamente» ${ }^{154}$, es cierto que sintoniza con el espíritu lateranense de promoción del estudio que el legado trató de generalizar en España. Además, es indudable que el culto obispo Bernardo II, el cual había sido visitado poco antes del sínodo por el legado $^{155}$, conocía bien las disposiciones de la Iglesia al respecto.

La constitución sinodal, a la que nos estamos refiriendo, es eminentemente práctica; establece que el arcediano, en cada uno de los arciprestazgos de su jurisdicción arcedianal, escogerá unos varones idóneos (no se determina número exacto), los cuales, bajo juramento de obrar de buena fe, le señalarán los clérigos hábiles para el estudio y con haberes económicos (beneficio o patrimonio) suficientes para costear su estancia en el estudio y a un vicario temporal en la iglesia que sirve. El arcediano, a su vez, rendirá cuenta de sus gestiones al arzobispo, el cual resolverá el asunto definitivamente ${ }^{156}$.

En el sínodo de 1289 , siendo arzobispo Rodrigo González de León (1286-1316), no se hace referencia directa a la ciencia que debe poseer o adquirir un clérigo curado, ni se legisla nada sobre los estudios a realizar,

152 ob. cit., p. 337.

153 lbid., pp. 337-338.

154 SH I, 263.

15s Ibid.

156 SH I, 264-265: «Primo, quod quilibet archidiaconus in quolibet archipresbiteratu de archidiaconatu suo eligat uiros ydoneos qui iurent ad sacrosancta Dei euuangelia, quod bona fide et sine malo ingenio denunciabunt ipsis archidiaconis clericos habiles ad studium, quorum facultates, tam de ecclesia quam de bonis patrimonialibus acquisite, mediocriter sufficiant ad prouisionem eorundem in studio et uicarii temporalis in ecclesia instituendi. Et hoc ipsum archidiaconi domino archiepiscopo communicent". 
pero hay en él un dato significativo sobre la exigencia de saber bien leer y cantar. En la constitución número 12 se establece que los rectores de iglesias, para la recitación de las horas, se ayuden de un clérigo o monaguillo bien instruido en la lectura y el canto, en latín por supuesto; y la importancia de este requisito se pone de manifiesto en la pena impuesta a los transgresores: la suspensión de oficio y beneficio ${ }^{157}$.

El sínodo de 1313, del arzobispo Rodrigo de Padrón (1307-1316), tampoco se ocupa directamente de la ciencia clerical, pero es digno de notar que en su constitución número 1 considera la razón del estudio como la única causa válida para poder dispensar de la obligación de residencia de los rectores parroquiales ${ }^{158}$.

Hasta bien entrado el siglo XV no encontramos nueva normativa gallega sobre el tema. En el sínodo compostelano de 1435, siendo arzobispo Lope de Mendoza (1399-1445), se afronta un problema de escasez de clérigos curados, que tiene su origen en la pobreza material de los candidatos, los cuales no pueden costearse los estudios necesarios y, en consecuencia, no llegan a ser promovidos; de este modo, los que fallecen no encuentran sustitutos. Como medida de urgencia para remediar la situación, se decide, no ya abaratar o subvencionar los estudios, sino rebajar ocasionalmente el nivel de exigencia de los curados, conformándose con que los clérigos candidatos sepan bien leer y cantar. Previo examen de ésta y de las demás cualidades requeridas (buenas costumbres, edad legítima, patrimonio, o beneficio, suficiente), se les concederá la licencia para ordenarse, aunque no sepan gramática ${ }^{159}$.

Indirectamente, esta disposición constituye un testimonio claro de que el examen de los candidatos se practicaba con regularidad y seriedad en la diócesis compostelana por este tiempo. De otra parte, se infiere que saber gramática, ser un buen gramático, significa aquí algo más que simplemente saber bien leer y cantar.

157 SH I, 275: «Statuimus quod quilibet rector habeat unum clericum uel monacellum ad minus bene informatum in cantando et legendo, qui ipsum ad horas dicendas iuuet. Quod nisi fecerit, et solus horas dixerit, sit ipso facto officio beneficioque suspensus».

158 SH I, 293: "Ut diuinus cultus non minuatur... Et prelatus siue rector in dicta ecclesia residentiam continuam faciat personalem, super qua residentia non facienda cum eodem nullus per nos nec per alium nisi ratione studii dispensari uolumus».

159 c.1 (SH I, 323): «Lo primero. Entre las otras cosas que se requieren para que los clerigos sean promovidos a ordees sacras, es neçesario al menos que sean gramatiquos; pero considerando nos, segundo nos fue fecha relaçion, que las iglesias curadas non son administradas nin regidas por defecto e mingoa de clerigos que falesçeron asy por mortaldades commo por cabsa que se non ordenaron por la pobresa para aprender gramatiqua, por ende querendo nos proveer sobrelo es nuestra merçede por la tal neçesidade que los clerigos que se quisieren ordenar que sepan bien leer e cantar, e sean de buenos costunbres, e de legitima hedad segundo lo requiere la orden a que se quisieren promover, e que tengan algun patrimonio o benefiçio por que se mantengan, se presenten ante nos para que los mandemos sobrelo examinar e les demos liçençia para que se ordenen, en caso que non sepan gramatiqua». 
Medio siglo más tarde, en la diócesis de Tuy, según testimonio del obispo Diego de Muros (1471-1487), la mayoría de los clérigos eran ignorantes, no sólo de las ciencias eclesiásticas propiamente dichas, como la teología y el derecho canónico, y de otras que convienen a los clérigos, principalmente curados, sino también de la gramática, de modo que no sabían ni entendían el latín. Algunos pícaros se aprovechaban de esta ignorancia para abusar de letras apostólicas y de otros escritos públicos y privados redactados en latín, haciéndolos valer fuera o más allá de lo en ellos contenido. Sirve de atenuante a esta situación el hecho de que la iglesia de Tuy llevara algo más de treinta años abandonada, a merced de las disputas de los nobles poderosos ${ }^{160}$.

Resuelto el problema, el obispo se propone la reorganización de la diócesis mediante las constituciones sinodales. En cuanto a la exigencia de ciencia para poder recibir órdenes sagradas, distingue dos niveles, uno para el subdiaconado (en el mismo nivel, al menos, habría que incluir al diaconado, que no se menciona) y otro para el presbiterado. La promoción a la orden de epístola exige saber bien leer, cantar y rezar las horas; la orden sacerdotal exige, además, saber regir el rezo de las horas canónicas y saber administrar los sacramentos ${ }^{161}$. Cita expresamente cuatro sacramentos: el

160 c.47 (SH I, 375-376): «Item porque la ynorançia es madre de todos los herrores, e en este nuestro obispado ay grande defecto de personas letradas, e la mayor parte de los clerigos de nuestro obispado non solamente son ynorantes de theologia, derecho canonico, e de otras sciencias que a clerigos conviene saber, mayormente a aquellos que tienen cargo de animas, mas aun por los grandes males e dapnnos que han venido sobre la nuestra iglesia cathedral e sobre las otras iglesias de nuestro obispado que ha trinta e tres annos que esta en tirania... ygnoran la gramatica e non saben ni entienden latin, donde han recreçido e recresçen cada dia muchos males, dapnnos e hyerros. E en espiçial, que algunos... E otros han tomado en nuestro obispado bullas antiguas de los Santos Padres que fueron de perdones e privilegios e de otras cosas, e dixieron que eran graçias expectativas... e otros con grand osadia an tomado e tomaron escrituras e contractos publicos e privados e fechos en latin, e dixeron que eran privilegios, bullas e registros apostólicos, e fatigaron con ellos las gentes».

Sobre las vicisitudes de la diócesis y la restauración de la normalidad se pronuncia el obispo con más detalles en el proemio a las constituciones sinodales. Al final del mismo expresa la razón de poner las constituciones en lengua vulgar: la ignorancia del latín de la mayor parte de los clérigos: «las quales por la grand ynorançia que fallamos <en> la mayor parte de los clerigos de nuestro obispado por non saber nin entender latin,mandamos escrivir e poner en vulgar, porque todos las entiendan» (SH I, 343-344).

161 c.12 (SH I, 357): «Item estabelesçemos e mandamos que los clerigos que se ovieren de hordenar, mayormente de hordens sacras, sean examinados commo el derecho manda. $\mathrm{E}$ antes que reçiban orden de epistola, sean examinados si saben bien leer e cantar y rezar las Horas canonicas. E antes que sean hordenados de horden sacerdotal, sean examinados primeramente sy saben rezar las Horas canonicas e regirlas por sy, e sy saben el ofiçio de bautizar e que lo lean despachadamente, syn duda en ella, pausada e licteradamente, e el ofiçio de la extremaunçion. En estas cosas sea todo clerigo examinado antes que le sea dado la horden saçerdotal, ni liçençia para la reçebir». 
bautismo, la eucaristía, el matrimonio y la extremaunción; sorprende la no mención del sacramento de la penitencia, administrado por los curados principalmente y al que se suele hacer mención prioritaria en este tipo de literatura. Bien es cierto, que en muchas otras constituciones del sínodo, números $20,29,30,31,53$ y 54 , sí se trata de este sacramento y de su administración preferente por los clérigos curados. En cuanto a los otros dos sacramentos que no se citan, confirmación y orden, su no mención está justificada en el caso, ya que su administración correspondía en exclusiva al obispo.

Ya en el siglo XVI, año 1526, el entonces obispo de Tuy, Diego de Avellaneda (1526-1537), denuncia en asamblea sinodal que muchos de sus clérigos no saben ni siquiera escribir. Como medida primera, de urgencia, el sínodo establece que los clérigos de orden sagrada (se sobreentiende: ignorantes) menores de treinta años estudien gramática, sin indicar para este caso un plazo de tiempo, por lo que debe entenderse un plazo prudencial, hasta que lo aprendan. Además, como medida preventiva, para el futuro, dispone que los clérigos que en adelante hayan de recibir alguna orden sagrada, antes habrán de estudiar tres años de gramática 0 , cuando menos, dos cumplidos, de modo que lleguen a ser buenos lectores y cantores de canto llano y que sepan escribir ${ }^{162}$.

Dos años después, en el sínodo de 1528, el mismo obispo Diego de Avellaneda regula de forma más completa la materia. En el libro primero, título cuarto, constitución primera, ordena que nadie sea ordenado de orden sagrada sin ser buen gramático y buen cantor ${ }^{163}$. En la constitución cuarta de los mismos libro y título recoge, en su tenor literal, la constitución número 12 del sínodo de 1482 , antes glosada ${ }^{164}$. En el título tercero del libro quinto trata de los maestros y de las cátedras. Su punto de partida es que ha observado durante la visita canónica una gran ignorancia en la mayoría de los clérigos, que "no saben gramatica ni cantar»; ello le lleva a la idea de fundar una cátedra de gramática y otra de canto, de cuya organización y financiación trata al final del sínodo y luego en el sínodo de 1529,

162 c.9 (SH I, 393-394): «Otrosy se mando que los clerigos de orden sacro que al presente estan hordenados, que no llegaren a la hedad de treynta años, que estudien gramatica; $e$ que los que se ordenaren de aqui adelante, primero que se ordenen de ningun orden sacro, estudien tres años de gramatica o a lo menos dos años cunplidos, de manera que sea habile para se poder ordenar y buen letor y cantor de canto llano, y que sepa escrevir, porque se halla por muchos clerigos no saber escrivir ninguna cosa".

${ }_{163} \mathrm{SH} \mathrm{I}, 411$.

${ }^{164} \mathrm{SH}$ I, 412. El sínodo de 1528 recoge la mayor parte de las sinodales de Diego de Muros (1482), como observan los editores del Synodicon, quienes precisan que, además, ambos sínodos forman *el código sinodal que regulará la vida de la diócesis, proclamándose la vigencia de entrambos todavía en 1627» (SH I, 396). 
constituciones $1-3^{165}$. El sínodo de 1543, siendo obispo Miguel Muñoz (1543-1547), en sus dos constituciones, ureglamenta ex novo el viejo tema de las cátedras de gramática y música ${ }^{166}$.

b) Portugal 167

Desde mediados del siglo XIII, las diócesis de Lisboa y Braga se hacen eco en sus sínodos de las determinaciones del legado Juan de Abbeville. Opino que esto se produce, en el caso de Lisboa, con independencia de su metropolitana, que era Santiago de Compostela; y en el caso de Braga, sin influencia en sus diócesis sufragáneas, las cuales, salvo la de Astorga, eran gallegas.

La constitución número 4 del sínodo de Lisboa de 1248, siendo obispo Aires Vasques (1244-1258), recoge con bastante precisión la exigencia mínima de ciencia para los clérigos, tal como figura en el concilio legatino de Valladolid de 1228.

En dicha constitución no se tiene en cuenta la posibilidad de realizar estudios superiores a esa exigencia mínima; tampoco se dan explicaciones sobre la motivación de la norma. Se adopta desde el principio un estilo impositivo directo; es como una transcripción simple y escueta, aunque no literal, de la norma en la que se basa, aun sin citarla de modo expreso.

La norma en cuestión dispone que no se admita a nadie a un beneficio, a una orden menor, ni siquiera a la tonsura, si no sabe leer, cantar y gramática; o, al menos, si no comienza a aprender.

$\mathrm{Si}$ alguno, de hecho, consigue la tonsura, las órdenes menores o un beneficio, siendo ignorante, será obligado a estudiar gramática hasta que llegue a dominar el latín. En garantía de cumplimiento establece un examen de idoneidad ante el obispo o su vicario ${ }^{168}$.

${ }^{165}$ SH I, 513, 528-530 y 533-534.

166 SH I, 538.

167 Isaías da Rosa Pereira ha dedicado algunas páginas a la formación del clero a través de los sínodos medievales portugueses en su estudio $A$ vida do clero e 0 ensino da doutrina crista atraves dos sinados medievais portugueses, "Lvsitania Sacra», 10 (1978), pp. 36-75; concretamente, pp. 36-41.

168 SH II, 298: «Item, quod nullus ad beneficium ecclesiasticum uel ad minores ordines seu etiam ad primam tonsuram admittatur antequam in eo sit utilitas legendi et cantandi et gramaticam adiscat, uel saltem adiscere incipiat, et postquam primam tonsuram uel minores ordines seu etiam beneficium ecclesiasticum fuerit adeptus, gramaticam adiscere compellatur donec latinis verbis competenter loqui sciat. Et ut hoc statutum melius obseruetur precipimus ut nullus de cetero ad beneficium ecclesiasticum admittatur nisi prius fuerit per episcopum uel per uicarium eius, absente episcopo, super premissis examinatusw.

Es evidente en el texto que el estudio de la gramática viene referido a la lengua latina; saber gramática es, en este momento, saber latín. 
Los sínodos de Braga de 1281 (constituciones 1, 2, 4, 22) y 1285 (constitución 5) ofrecen una normativa más completa sobre el tema y citan expresamente la constitución legatina como su fuente. Ambos sínodos pertenecen al gobierno del mismo obispo, fray Tello (1279-1292), por lo que es lógico que las diferencias entre ellos, en cuanto a la normativa que nos ocupa, sean sólo de detalle; lo cual nos permite glosar sus disposiciones de modo conjunto.

La normativa está motivada en el peligro espiritual que conlleva la ignorancia de los clérigos. Por ello, dispone que los clérigos seculares ${ }^{169}$ que no sepan latín lo estudien hasta aprenderlo.

Esta regla general tiene dos excepciones: una, la incapacidad para el estudio por razón de la edad, que se fija en los treinta años cumplidos; otra, la falta de medios económicos para financiar los estudios ${ }^{170}$.

A este respecto, la constitución 22 del sínodo de 1281 permite a los rectores de iglesias conceder ayudas económicas (becas) a escolares pobres que deseen estudiar, en consonancia con las directrices canónicas sobre facilitar el estudio. Que se trata en el caso de escolares clérigos aparece claro por el contexto; la constitución, toda ella, hace referencia a los clérigos ${ }^{171}$.

Lo señalado constituye la exigencia mínima y general para todo el clero secular. Luego, en otra constitución, establece que para ser promovido al subdiaconado, primera de las órdenes mayores o sagradas, el clérigo deberá saber latín; o, al menos, cantar y leer bien. En realidad, no se ve aquí un aumento real de exigencia, ni una diversificación, respecto de los clérigos menores; a fin de cuentas, se queda en lo mismo, en la exigencia mínima de saber bien leer y cantar en latín; vale, en todo caso, como una especificación y llamada de atención al ordenando de subdiácono.

169 Véase la nota 75 sobre la especificación de clérigo secular.

170 Sínodo de 1281, c.1 (SH II, 11): «Nos frater Tellius diuina paciencia (sic, por prouidencia) sancte Bracarensis ecclesie archiepiscopus, prouidere curantes ne ex deffectu studiorum et literature periculosa et intollerabilia detrimenta proueniant animabus, statuimus ut omnes benefficiati in ecclesiis qui latinis uerbis loqui nesciunt, excemptis illis de quorum profectu propter etatem non est sperandum, studio dent operam quousque latinis uerbis sciant loqui, nisi adeo habeant exile benefficium quod non possint per ipsum commode sustentari».

Sínodo de 1285, c.5 (SH II, 29): *Item quod ars artium est regimen animarum et idcirco in illis qui ad regimen huius assumuntur propensius est litterarum ignorancia propulsanda, statuimus ut omnes clerici seculares qui latinis uerbis nesciunt loqui, exceptis illis de quorum profectu propter etatem non est sperandum, utpote in anno xxx. constitutis, quod primo loqui latinis uerbis adiscere studeant*.

171 SH II, 18: «... uniuersos et singulos rectores ecclesiarum nostre diocesis monemus sollempniter quod de cetero sine nostro consensu nemini prestimonia, casalia, decimas seu porciones in suis ecclesiis assignent... Non autem inhibemus quin benefficiant scolaribus pauperibus uolentibus studere». 
De otra parte, en referencia a los clérigos beneficiados, con o sin cura de almas, que estén dispuestos a un mayor aprovechamiento en el estudio de la gramática, concede, de acuerdo con la normativa legatina, que dichos clérigos perciban íntegramente las rentas de sus beneficios, como si sirvieran personalmente en su iglesia, mientras están dedicados al estudio, durante un trienio continuo.

El cómputo del trienio se iniciará en la próxima fiesta de san Lucas, 18 de octubre, señalada así como fecha de inicio del curso escolar. Los que quieran acogerse a este privilegio, que suponía una residencia, al menos formal, fuera del lugar del beneficio, no pudiendo ya hacerse cargo personal del mismo, proveerán a que su iglesia quede asistida por un presbítero y un clérigo ayudante ${ }^{172}$.

El sínodo de Lisboa de 1307, bajo el gobierno del obispo João Martins de Soalhães (1294-1313), no dedica directamente ninguna constitución al tema, pero viene al caso resaltar que en la constitución 21 recoge el privilegio que asiste a los rectores parroquiales de ser dispensados de la obligación de residencia por razón del estudio. Si bien no considera esta causa como la única legítima de dispensa, sí es ésta la única que especifica, con lo que da a entender, lógicamente, que su legitimidad no se deja al criterio del obispo, aunque siempre quedará a su criterio el juicio sobre la conveniencia o no de la concesión de la dispensa en cada caso ${ }^{173}$.

En esta misma línea, el sínodo de Braga de 1326, siendo obispo Gonzalo Pereira (1326-1348), en la constitución número 2, recoge de modo expreso la razón de estudio como causa razonable de dispensa de la residencia y del servicio personal, referida en este caso a los racioneros ${ }^{174}$.

172 Sínodo de 1281, c.2 (SH II, 11): «Illis autem de re \{sic, por qui studere\} in gramatica et proficere uoluerint misericorditer indulgemus ut beneficia sua per trienium in scolis integre habeant continue ac si in suis ecclesiis deseruirent, prouiso nichilhominus ut in qualibet ecclesiarum unus presbiter cum socio clerico ad minus remaneat qui ministret populo ecclesiastica sacramenta que ministrari sinuntur durante tempore interdicti».

Sínodo de 1285, c.5 (SH II, 29): "Illis autem qui studere in gramatica et proficere uoluerint misericorditer indulgemus ut beneficia sua cum cura uel sine cura integra, iuxta moderationem alterius nostre constitutionis quam super hoc in alia nostra synodo edidimus, usque ad terminum computandum a festo beati Luce proximo uenturo in scolis habeant ac si in suis ecclesiis personaliter deseruirent $m$.

Ambos párrafos son continuación de los transcritos en la nota 170.

${ }_{173}$ SH II, 312: «Item, statuimus quod rectores ecclesiarum parrochialium nostre diocesis ut in ecclesiis in quibus etiam de iure residentiam facere tenentur saltem per duos menses continue residentiam faciant, nisi ratione studii aut alterius legitime cause siue nostra uel successorum nostrorum licentia eos contigerit absentari, alias contrarium facientes a suis beneficiis per annum duximus suspendendos».

174 SH II, 40: «Cum satis sit ut clericus pro tempore quo seruit altari uiuere debeat de eodem, quia nonnulli porcionarii... non eas aliter sed tantum pro tempore seu diebus quibus 
Hasta 1403 no tenemos nuevos textos sinodales portugueses que traten sobre la ciencia clerical. Parece, pues, en este aspecto al menos, que la repercusión del concilio legatino de Valladolid de 1322 en las diócesis portuguesas es mucho más tardía que la que tuvo la normativa legatina de Juan de Abbeville un siglo antes.

Las constituciones sinodales de Lisboa de 1403, siendo arzobispo João Afonso Esteves de Azambuja (1402-1415), constituyen un cuerpo documental de gran valor para la historia religiosa y social de la nación portuguesa de principios del siglo $\mathrm{XV}^{175}$.

Por lo que hace al tema aquí tratado, interesa la constitución número 2. Contiene, en primer lugar, una declaración general de la obligación de los clérigos, de todos y especialmente de los de órdenes mayores o sacras, de los rectores o párrocos y de los beneficiados, de conocer su oficio y aquellas cosas que deben enseñar a los demás. Luego, en plan normativo, partiendo de la consideración (implícita, pero clara en el texto) de que la ignorancia clerical es un defecto generalizado, establece que los ordenados de órdenes sacras y los beneficiados, curados o simples, que sean hábiles (referencia a la falta de irregularidad por defecto o por delito) y que demuestren condiciones y disposición, se dediquen a aprender gramática (latín) para entender los rezos y lecturas, y canto para hacer o ayudar a hacer los oficios.

Preocupado por la observancia de la norma dada, avisa que en la visita diocesana, que piensa llevar a cabo después del segundo sínodo ${ }^{176}$, comprobará el cumplimiento o no de lo establecido en este primero y castigará a los transgresores con la privación de sus respectivos beneficios, que se reservarán para otros que sepan las ciencias exigidas y puedan servir así su oficio debidamente.

Por otra parte, pensando en el futuro, establece que en adelante no se admitará a nadie (confesión indirecta de que se practicaba lo contrario) a órdenes o a beneficio simple, sino a quien sepa bien cantar y sea gramático; ni a beneficio curado, sino a quien, además de lo dicho, sepa la doctrina cristiana que debe enseñar, cuyo contenido señala en este orden: artículos de la fe, sacramentos de la Iglesia, preceptos de la ley, siete obras de misericordia, siete pecados mortales y su penitencia correspondiente, casos reservados al obispo ${ }^{177}$.

seruierint ecclesiis porciones eis tribuant seu ministrent, exceptis illis quos infirmitas seu iusta rationabilis necessitas aut euidens ecclesie utilitas excusaret uel si nos seu subcessores nostri alicui uel aliquibus propter studium uel aliquam rationabilem causam eas aliter mandauerimus ministrari».

175 Cf. SH II, 318.

176 Sínodo que no se celebró, como señala I. da RosA PereirA, ob. cit., p. 40.

177 SH II, 320: «Item, porquanto a todollos clerigos e specialmente aos dordees sacras... ordenamos que todollos que ora som ordenados de ordees sacras ou ham beneficios curados ou outros sinplezes e forem habilles e aptos e despostos pẽra ello se trabalhem daaqui em delan- 
En resumen, el clérigo cura debe ser gramático y debe saber la doctrina cristiana básica. Un detalle a comentar es que en este sínodo se da por supuesto que los clérigos sabían leer latín, aunque sus conocimientos gramaticales, en muchos de ellos, no eran suficientes como para captar bien lo que leían; sabían leer latín materialmente, pero no eran gramáticos.

El sínodo de Lisboa de 1403 es, en cuanto a la documentación sinodal llegada hasta nosotros, como un oasis en el desierto de disposiciones sinodales portuguesas sobre el tema entre finales del siglo XIII (sínodo de Braga de 1285) y mediados del siglo XV.

En 1444, João Afonso Ferraz I, administrador del territorio diocesano portugués del obispado de Tuy con sede en Valença do Minho (14221462), celebró un sínodo en el que promulgó varias constituciones de corrección y reforma.

Según se precisa en el proemio, no se trata de constituciones nuevas, sino de una selección de constituciones anteriores hechas y ordenadas en la iglesia de Tuy, consideradas importantes y pertinentes en el momento para el servicio de Dios y el bien de clero y pueblo ${ }^{178}$.

La constitución número 4 se refiere a lo que deben saber los clérigos. Denuncia la ignorancia de algunos sacerdotes y rectores, que, según le consta por cierta información ${ }^{179}$, llegan al extremo de no saber leer bien la sacra, es decir, el canon de la misa. En consecuencia, establece, bajo pena de excomunión, que todos los sacerdotes, especialmente los curados, aprendan

outros sinplezes e forem habilles e aptos e despostos pera ello se trabalhem daaqui em delante de aprenderem gramatica pera por ella entenderem o que rezam e leerem, ou canto pera officiarem e fazerem e ajudarem a fazer os officios da Egreja... em tal gissa que, em a primeira visitaçom que se fezer depois do segundo synado, achemos que se trabalharam os que pera ello forom despostos... sô pena de seerem privados dos beneficios que ouverem, pera os averem outros que saibam as dictas sciencias e os possam servir como devem e som theudos; e sô a dicta pena mandamos a quasesquer priores e vigairos e outros quaaesquer que teverem cura de almas que se trabalhem de saber bem e compridamente quaaes e quantos som os artigos da fé e sacramentos da sancta Egreja e preceitos da lei e as sete obras da misericordia e sete pecados principaes mortaaes e que peendença devem de fazer aquelles que os cometem, $e$ quaaes e quantos som os cassos a nós specialmente reservados... e estabelecemos que nom seja nemhuu de nosso arcebispado pera aver ordẽes ou beneficio sinplez salvo sabendo bem cantar ou seendo gramatico, e pera aver beneficio curado que aja as dictas sciencias e os dictos artigos da fé e as outras cousas sobredictas que perteceem a saber aaqueles que teem rigimento de cura de almas".

178 Proemio (SH II, 424-425).

179 Aunque la frase «por cierta información» no concreta bien la fuente de información del obispo y, probablemente incluso, ni siquiera apunta a una fuente de información propia del obispo en cuestión, sino que se trata de una terminología heredada, usual, es válida en cuanto manifiesta, si no ya el conocimiento directo, cuando menos la convicción del obispo y de los sinodales respecto a la ignorancia de algunos de los clérigos de la diócesis. 
a leer con soltura, de modo que celebren bien los oficios y administren correctamente los sacramentos; que sepan bautizar, dar la comunión, bendecir a los que se casan, ungir a los enfermos y enterrar a los muertos. Insiste sobre todo en que lean bien la sacra, utilizando siempre el libro.

La redacción no es suficientemente precisa en un punto; mientras que la denuncia de ignorancia se refiere a algunos, la disposición obligando a aprender alcanza, en su redacción literal, a todos los sacerdotes, como si, realmente, todos, y no sólo algunos, fueran ignorantes ${ }^{180}$.

Para los clérigos aspirantes al sacerdocio dispone un examen previo de suficiencia, tal como manda el derecho canónico. Dicho examen se centrará especialmente en la buena lectura de la sacra y en el conocimiento del oficio de curado. Quien no supere el examen no será admitido al sacerdocio ${ }^{181}$.

Al final de la constitución que glosamos vuelve sobre el tema del examen de suficiencia para los ya ordenados de presbíteros: si no aprobaren el examen serán suspendidos del ejercicio de sus órdenes y se les privará de los beneficios que tuvieren, sin otra esperanza de restitución que la adquisición de los conocimientos requeridos ${ }^{182}$.

La redacción resulta bastante inconcreta también en este punto; parte de una condición, «se per nós forem examinados", que no se sabe muy bien qué sentido tiene; quizá pensaba asumir él mismo la tarea de examinar la ciencia de sus sacerdotes durante la visita canónica, o en una visita ad hoc, o aprovechando un próximo sínodo, o haciendo que se fueran presentando a él periódicamente, o en otra forma. Pero lo que llama la atención no es tanto la referencia a la persona misma del obispo como examinador, cosa que admite la posibilidad de que el examen se hiciera mediante delegados suyos, sino el hecho mismo de condicionar el examen, de no precisar si se llevará a cabo realmente, si se examinará a todos sin distinción, cómo y dónde.

Tampoco se dice nada sobre cómo podrán aprender lo que se les exige

180 SH II, 427: «Item, porque achacamos por certa emfformaçom que allguuns rectores e sacerdotes som ignarios em os officios divinos celebrar... mandamos em virtude de obediencia e sob pena d'excomunhom a todos os sacerdotes, especiallmente aquelles que ham cura d'almas, que de todo em todo aprendam em guisa que leam desenbargadamente e perfectamente celebrem os officios divinos e saibam dar os sacramentos e especiallmente que bem e verdadeiramente leeam a sacra... Esto mandamos que faça no oficio de baptizar e comungare e nos das bençõees dos que cassam em face da Igreja e no oficio de ungir e enterrar».

181 Ibid.: «Mandamos ainda quando allguun ouver de resceber ordens de missa que ante que seja promovido aas dictas hordens que seja examinado segundo os direitos mandam em tall caso, especiallmente em leer a dicta sagra e os dictos oficios e em nos hordepnar segundo se deve fazer. E se nom for achado suficiente pera o dicto officio nom seja rescebido aa dicta hordem».

182 Ibid.: «E sejam sabedores os dictos sacerdotes que se per nós forem examinados e pera esto nom forem achados ydoneos que nós os sospenderemos das dictas hordeens e beneficios se os teverem, sem esperança doutra restutuiçom». 
saber: lugar de estudio, maestros, tiempo o plazo del aprendizaje, condiciones, etc. Al menos, al tratar del examen de los aspirantes resuelve los posibles interrogantes remitiendo de forma global al derecho vigente: "segundo os direitos mandam em tall caso".

Durante la segunda mitad del siglo XV la normativa sinodal portuguesa sobre la ciencia clerical se concentra en tres nombres: Luis Pires, Diogo de Sousa y Pedro Vaz Gavião.

Luis Pires, primero como obispo de Evora (1464-1468) y luego como arzobispo de Braga (1468-1480), trató de impulsar con espíritu decidido la reforma del clero; celebró dos sínodos en Evora (años 1466 y 1467) y uno en Braga (año 1477).

Del sínodo de Evora de 1466 no se conserva el texto, pero conocemos el contenido parcial de la constitución número 39. En ella se establecía que los clérigos que no supieran cantar debían aprender en el plazo de un año; pasado el año sin aprender canto, ipso facto, los beneficiados quedaban suspendidos de la percepción de sus rentas beneficiales y los no beneficiados no deberían ser recibidos en las iglesias y no se les debería facilitar el avío para celebrar. A su vez, los que no cumplieren con dicha norma quedaban excomulgados.

Así consta en la constitución única del sínodo de Evora de 1467, justo al año del sínodo anterior. El obispo, a punto de cumplirse el plazo de un año concedido para el aprendizaje, es consciente de que no se ha observado la normativa y de que, por ello, la mayor parte de sus clérigos van a quedar excomulgados.

En esta situación, con el beneplácito del cabildo y de toda la clerecía, suaviza la disposición anterior. A este efecto, deroga la pena de excomunión; por lo demás, se mantiene la obligación de los clérigos de aprender a cantar y de ser letrados, y será el propio obispo quien juzgará de la idoneidad de cada cual, determinando en cada caso lo que considere más oportuno ${ }^{183}$.

En realidad, el obispo ya se había reservado en la constitución número

183 SH II, 219-220: «Fazemos saber que... anno passado da era de mill e quatrocentos e sasenta e seis, fezemos e hordenamos certas constituiçoves... Antre as quaaes fezemos e estabelecemos hua constituçom, scripta aas trinta e nove constituçõoes, a quall começa: Posto que na Egreja de Deus há mayores officios etc., per a quall mandamos que todos os clerigos que nom sabem cantar aprendam a cantar da dada e provicaçom das dictas constituçõoes a huum anno. $O$ quall termo passado, per ella meesma sospendemos os clerigos beneficiados da percepçom das rendas de seus beneficios e mandamos que os clerigos nom beneficiados nom sejam recebidos en egrejas nem lhes seja dado guisamento pera cellebrar missas etc. E fazemdo... o contrairo passado o dicto termo, posemos e ouvemos por posta em elles e cada huum delles e isso meesmo em aquelles que lhes acudissem com as dictas remdas e dessem guisamento sentença d'excomunhom em scripto, segundo todo esto e outras cousas mais compridamente som scriptas na dicta constituçom. E agora em este presente signodo, esguardando nós como os dictos clerigos eram negrigentes... e como todos ou quasy a mayor parte dos dictos clerigos, beneficiados e nom 
39 del sínodo anterior el juicio definitorio sobre quiénes en ese momento debían empezar a tomar lecciones y quiénes estaban dispensados de la obligación del aprendizaje, o por ser ya letrados o por ser viejos. Desde ahora, quedarán todos a la determinación personal del obispo, lo que en la práctica significaba que cada clérigo seguiría en su sitio mientras que el obispo, por si mismo o por requirimiento de terceros, no resolviera otra cosa.

A fin de cuentas, la nueva norma significa una rendición en toda regla del obispo ante la situación de hecho.

Diez años más tarde, siendo Luis Pires arzobispo de Braga, tiene la ocasión de volver a insistir en el tema del canto sacro y de la ciencia clerical.

En la constitución número 27 del sínodo de 1477, tras una loa apasionada a la importancia cultual del arte sacro musical, denuncia la ignorancia de muchos clérigos y religiosos ${ }^{184}$, que llega a extremos muy preocupantes: no saben ni entienden nada de latín; más aún, no saben cantar ni se interesan por saber; $y$, lo que es mucho peor, ni siquiera saben leer sino muy mal, y no saben tampoco las cosas propias de los clérigos. En consecuencia, dispone que corrijan su ignorancia en el plazo de un año, al cabo del cual serán examinados conforme a lo que cada uno debe saber por razón de su "orden».

El examen y el juicio sobre la edad, capacidad de aprendizaje y suficiencia de conocimientos se los reserva para sí el obispo, salvo que en algún caso crea oportuno delegar en otra u otras personas.

En cuanto a la pena a imponer a los infractores, observamos una gran cautela; influye, sin duda, la experiencia de Evora, por lo que se limita a asegurar que pondrá en ejecución lo establecido en los cánones, sin más precisiones. No indica apenas nada sobre los medios a disposición de los clérigos afectados para subsanar su ignorancia; sólo alude al breviario (libros del coro) y al misal ${ }^{185}$.

Me pregunto si ese silencio significa que los clérigos de la diócesis, en

beneficiados, passado o dicto termo, encorreriam em sentença d'escomunhom... Porem nós, a requirimento e petiçom do dicto nosso cabiido e perssoas delle e de toda nossa clerizia durando ainda o dicto termo prefixo de huum anno e ante de seer fiindo e acabado, sospendemos e avemos a dicta excomunhom, ex nunc prout ex tunc et ex tunc prout ex nunc, e avemos por nehua ... moderamos a dicta constituçom e reservamos pera nós a disposiçom e ydoneydade dos sobredictos clerigos, beneficiados e nom beneficiados, assy como fizemos na dicta meesma constituçom acerqua dos que fossem leterados ou velhos, os quaaes starom aa nossa determinaçom».

${ }^{184}$ Destaca en el texto la referencia a la ignorancia de los religiosos de Braga en esa época. Por lo general, las alusiones a los religiosos en los sínodos denotan en ellos un saber teológico más amplio.

185 SH II, 100-101: «Item... a musica e arte de cantar em seu modo hé muito necessaria, porque per ella Deus hé muito louvado... E porque nas egrejas e moesteiros deste arcebispado achamos muitos clerigos ou religiosos asy beneficiados como nom beneficiados que lhes non abasta non seren leterados ao menos daquella sciencia que os direitos chamon conpetente nen soomente saberen nen entenderen alguun pouco de latin, mais ainda tanta hé a sua negli- 
general, disponían de manuales, o de maestros, o de ambas cosas a la vez. Desde luego, manuales de confesión y de los sacramentos en general, unos amplios otros breves, circulaban bastantes por este tiempo, segunda mitad del siglo XV. Que hubiera escuelas y maestros a mano de los clérigos, a los que se refieren los sínodos, por ejemplo en iglesias más o menos céntricas dentro de los arcedianatos, es poco probable.

En este sentido me parece acertada la observación de I. da Rosa Pereira: «Os estatutos sinodais referem-se, como é óbvio, ao clero espalhado pela diocese e que não tinha facilidade de acesso às escolas. Havia, assim, uma maioria de clero pouco instruido ao lado de alguns com cultura universitária, mas estes não iam para as igrejas rurais, ficavam pelas igrejas catedrais, pelas colegiadas, exerciam cargos na cúria diocesana, ou até na corte. O clero paroquial, fora da cidade episcopal, encontrava-se com o bispo por ocasião do sínodo diocesano... Encontrava-se também com o bispo ou seu delegado por ocasião das visitas paroquiais, que sabemos serem muito frequentes durante os seculos XV, XVI e XVII Mas estes encontros não eram suficientes para uma instrução mínima do clero, se bem que o bispo e os visitadores procurassem motivá-los para o bom e eficaz desempenho do seu ministério" ${ }^{186}$.

Esta observación, hecha por da Rosa Pereira para la iglesia portuguesa bajomedieval, vale por un igual, en líneas generales, para el resto de las diócesis hispanas en ese tiempo; cabe recordar en este sentido lo que testimoniaba el autor anónimo del Speculum, respecto de España e Italia, sobre los clérigos con estudios, que no se conformaban con beneficios pobres ${ }^{187}$.

Diogo de Sousa fue obispo de Porto (1496-1503) y luego arzobispo

gencia que non saben cantar nen o queren saber, e o que muito pior hé leer senon mui mall. Nen saben as outras cousas que pertecen ao clerigo ... Porém per esta presente constituçon signodall mandamos a todallas perssoas eclesiasticas... de todo nosso arcebispado, scilicet, os que non son velhos nen leterados que daqui a huun anno se trabalhen e aparelhen pera saberen cantar per arte musica en tall guisa que acabado o anno elles e cada huun delles o saiba ben fazer. E quanto hé os que non saben ben leer nen as outras cousas que per rezon de suaben fazer. E quanto hé os que non saben ben leer nen as outras cousas que per rezon de sua orden lhes pertece saber, nós lhes mandamos que dentro no dicto anno se trabalhen de sabere saiban muy ben e desenpachadamente leer e aprehendan muy ben a sacra e as cirimonias da missa e como han de dar e administrar os sanctus sacramentos e como han de rezar o domingall e santall per todo anno assy pellos livros do coro como pello missall do altar, segundo cada huun per ben de suas ordens que tever for obrigado saber, en tall guisa que quando per nós foren examinados já cada huun saiba todo o que pertece e deve saber. E o juizo das ydades, da velhice e da literadura e do contrairo reservamos pera nós, salvo se tall juizo a outra ou outras perssoas per nossa spiciall comisson cometêremos. E sejan certos que quando for o tenpo do dicto exame os que acháremos ydoneos ou pello contrairo, executaremos o que os sanctos canones en tall caso mandon e requeren».

180 ob. cit., p. 41.

187 Véase la nota 68. 
de Braga (1505-1532). En ambas diócesis celebró sínodo, los años 1496 y 1505 respectivamente, con constituciones paralelas en su gran mayoría.

En lo que se refiere a la ciencia clerical, las disposiciones son idénticas en ambos sínodos, casi verbo ad verbum. Se ocupa del tema en cuatro constituciones, que corresponden a los números $9,30,34$ y 36 del sínodo de Porto y, correlativamente, a los números $8,28,32$ y 34 del sínodo de Braga. La identidad llega a ser tal que afecta incluso a un aspecto que, en principio, cabría pensar como original en cada caso, como es la fuente de información que se alega en la parte motiva de algunas constituciones. Así, en la número 9 de Porto se dice: "Sabendo per muitos dinos de creer com quanta inorancia neste bispado...», y en la número 8 de Braga: «Sabendo per muitos dignos de creer com quanta ignorancia neste arcebispado...".

Sin descartar que, en efecto, el obispo se haya podido informar en ambos casos por medio de personas fidedignas, me inclino a pensar que se trata de una fórmula estereotipada de introducir la norma, aunque en el fondo la denuncia de ignorancia responda a una realidad conocida por todos los implicados. En teoría, en el caso concreto de Porto y Braga, habría que tener también en cuenta la proximidad geográfica de ambas diócesis y la cercanía de sus sedes respectivas para entender su alegación por igual en una y otra ${ }^{188}$.

En cuanto a la normativa misma, interesa destacar la insistencia del obispo en denunciar la ignorancia, de una parte, y, de otra, en señalar el remedio que debe aplicarse.

En la constitución número 9 de Porto ( 8 de Braga) denuncia la ignorancia de los clérigos, especialmente de los curados: no saben leer bien y cometen vicio en las palabras, llegando a administrar sacramentos, como el del bautismo, inválidamente, con defecto de nulidad en la forma. Como remedio, dispone que todos los clérigos, y en especial los curados, aprendan a leer, cantar y rezar según lo exige el oficio de cada cual; aprenderán asimismo a manejar el breviario y el misal; deberán saber la sacra de memoria, pero a la hora de la misa no se fiarán de la memoria, sino que la leerán pausadamente, y harán lo mismo en la administración de los demás sacramentos, sobre todo en el del bautismo. Los que, pasados seis meses desde la publicación de la sinodal, fueren hallados culpables de error, por su ignorancia, en la celebración de la misa o en la administración de los sacramentos, pagarán quinientos reales (se entiende que por cada vez); y, si

188 El ejemplo aquí puesto se repite, con fórmulas parecidas, en otras constituciones de ambos sínodos: números $13-11,18-16,25-22,26-23,30-28,31-29,33-31,37-35,42-39$, 46-41. 
permanecen contumazmente en su ignorancia, serán suspendidos de sus oficios y beneficios ${ }^{189}$.

Aunque no se precisa muy bien a quiénes afecta cada grado de exigencia, parece bastante claro que la exigencia general, para todos los clérigos, es la de aprender a leer, cantar y rezar, mientras que en el resto se refiere a los curados.

De otra parte, observamos el mismo «olvido" que hemos señalado anteriormente: no se indican los medios para el aprendizaje, dando por supuesto que los tienen a disposición, lo cual, por lo demás, si nos referimos a escuelas y maestros de gramática, no nos consta que los tuvieran a mano; sí tenían, sin duda, los libros propios de sus oficios, en los que debían ejercitarse hasta dominarlos, como el breviario, el misal, el sacramentario, etc.; a los cuales habría que añadir el de las constituciones sinodales, si bien, en cuanto a éste, se deja constancia de que había muchos fallos ${ }^{190}$.

En la constitución número 30 (28 de Braga) se contiene una nueva denuncia, esta vez indirecta, de la ignorancia clerical. Se lamenta la ignorancia supina de los feligreses, provocada por la ignorancia culpable de los curados ${ }^{191}$.

En la constitución número 34 (32 de Braga) se vuelve sobre el tema, sin previa denuncia de la ignorancia clerical. En ella se recoge la exigencia canónica de ciencia en su doble vertiente de ideal y de requísito mínimo. El ideal es que el clérigo tenga el grado de ciencia suficiente para entender la

189 SH II, 361 (Porto): «Sabendo per muitos dinos de creer com quanta inorancia neste bispado os sacramentos da Igreja se ministram, estabellecemos e mandamos sob pena descomunham a todollos clerigos, especialmente aos de missa que tem cura dalmas, que daqui em diante aprendam a leer, cantar e rezar como a seu officio som obrigados... E saibam reger o breviairio e assi digam missa mansso e apontadamente, especialmente as palavras da sacra, as quaes devem saber de coor e dizer pello livro... E assi lhe mandamos que os outros sacramentos especialmente o do bautismo cellebrem e dem pausadamente, leendo de maneira a forma delles que nom errem nas palavras nem nas silabas que ham de dizer, cá muitas vezes por nom saberem leer e ministrar os ditos sacramentos e o que leem nom hir bem liido e declarado, algũus nom receberam sacramentos que cuidam teer recebidos. E aquelles que nesta inorancia forem culpados, da pobricaçam desta a seis meses, pagaram quinhentos reaes se no dizer misa ou ministrar dos sacramentos errarem, e durando em sua inorancia e contumacia seram suspenssos dos officios e beneficios». El texto, idéntico, del sínodo de Braga puede verse en SH II, 146-147.

190 He aquí, por ejemplo, el testimonio que nos ofrece un auto de 25 de marzo de 1480 sobre el incumplimiento de los rectores de iglesias de copiar y exponer a lectura pública las constituciones del sínodo de Braga de 1477: «Item, des aquelle dia que o dicto sancto signodo celebramos atee o dia d'oye esperamos que os dictos beneficiados fezessem escrepver as dictas nossas constituiçōoes no dicto sinodo com elles ordenadas e as trouxessem ou emviassem a nós pera as veermos... E nunca dello curarom nem oje em dia curam e se leixam encorrer nas pennas na dicta constituiçom contheudas» (SH II, 136).

191 SH II, 377 (Porto): «Item, porquanto somos ora emformado, per os visitadores que ateequi forom neste bispado e assi per muitas pessoas dinas de creer, que muitos freigueses assi homes como molheres das igrejas deste nosso bispado, per sua negligencia e rudeza e culpa dos abades e capellāaes, nom sabem o Pater noster, nem Ave Maria, nem mais pouco 
Biblia; y lo mínimo exigible es que sea gramático para saber lo necesario a su oficio, como, por ejemplo, los cánones penitenciales, en clara alusión a la principalidad del sacramento de la penitencia en el ejercicio de la cura de almas.

La conclusión normativa consecuente a esta reflexión se concreta en que el aspirante al sacerdocio o a un beneficio eclesiástico deberá saber bien leer, cantar y gramática, además de poseer las otras condiciones de edad y honestidad, todo lo cual lo demostrará en un examen de idoneidad ${ }^{192}$.

La constitución 36 (34 de Braga) deja entrever descarnadamente la falta de confianza del obispo en que sus sacerdotes, en términos generales, estén en disposición de adquirir la ciencia necesaria para cumplir bien el oficio.

Se refiere, en el caso, a la administración de la penitencia y a la enseñanza de la doctrina cristiana. Vuelve a denunciar la ignorancia de muchos rectores de iglesias y, desesperanzado de hallar remedio cumplido, como sería el adquirir los conocimientos mínimos requeridos, dicta una medida práctica: que todos tengan por escrito en sus iglesias un sumario breve, en el que constarán los preceptos divinos, los pecados mortales con sus circunstancias, los artículos, las obras de misericordia, los cinco sentidos y otras cosas.

Esta tabla de la doctrina no existía en el obispado de Porto, y Diogo de Sousa afirma que la va a mandar elaborar rápidamente, para que en el plazo de cuatro meses, a contar desde la publicación de las sinodales, la tengan todos en sus iglesias, bajo pena de trescientos reales, que se aplicarán a las obras de la catedral y al juez diocesano ${ }^{193}$.

sabem os preceptos e mandamentos, nem as obras de misericordia, nem os peccados mortaaes...». El texto correspondiente al sínodo de Braga puede verse en SH II, 161-162.

192 SH II, 379-380: «Item, porque antre as cousas que muito necessarias som ao sacerdote assi hé sciencia pera emtender a santa Escritura e ao menos deve de seer gramatico para que emtenda as cousas que de necessidade deve saber, assi como som os Canones penitenciaaes e outras cousas à sua hordem e officio necessarias, porem nós amoestamos a todos aquelles que quiserem seer sacerdotes ou aver beneficios, que saibam leer, e cantar, e gramamtica, e vivam bem e onestamente. E sejam certos que se no exame nom forem achados autos e idoneos em idade e calidade e nas outras cousas suso ditas, que os nom receberemos a ordẽes sacras nem a beneficios de cura, nem a dignidades, nem a conisias da dita nossa igreja». El texto del sínodo de Braga puede verse en SH II, 164.

${ }^{193}$ SH II, 381-382: «Item, seendo nós emformado de quanta inorancia há acerqua de muitos abades e capellãaes deste nosso bispado, e consirando a muita necesidade que os curas das igrejas tem de saber decernir antre lepra e lepra... E querendo em algua parte proveer a isto, pois que compridamente nom pode seer, vista a corruçam da gente e como ao mal som mais inclinados que ao bem, ordenamos e mandamos que todollos abades de nosso bispado, de pobricaçam desta a quatro meses, tenham em suas igrejas escritos os preceptos e mandamentos e assi os peccados mortaaes e como se nelles pecca, e assi os artiigos da fé destintos, e os sacramentos da Igreja quantos sam e como forom instituidos, e outras cousas segundo se conteerá em hũu sumário breve que disto esperamos mandar fazer, e assi das obras de miseri- 
El texto de la tabla, mutilado en su principio en el ejemplar incunable existente (comienza en el noveno mandamiento), figura en apéndice a las sinodales, y se puede considerar como el más antiguo catecismo portugués impreso $^{194}$.

En el sínodo de Braga de 1505, constitución 34, paralela a la que glosamos, no se adjunta dicha instrucción cristiana, pero hace una llamada al "sumário breve que disto mandámos já fazer» ${ }^{195}$.

En ambas constituciones, 36 de Porto y 34 de Braga, en su parte final, se establece, como disposición complementaria, que aquellos clérigos que deseen recibir carta de cura, cuando se presenten ante el obispo o su vicario para el examen, traerán consigo el breviario y el sumario de la doctrina, y prestarán juramento de que dichos libros son suyos. $\mathrm{Si}$, con esto, fueren hallados idóneos, obtendrán la carta de cura; de lo contrario, no ${ }^{196}$.

Lo novedoso de esta norma está en que añade un requisito más a los exigidos por los cánones; las condiciones de edad, honestidad y ciencia no serán suficientes si no se tiene breviario y sumario de la doctrina propios. Se puede considerar como un requisito de garantía, y cuasi-sustitutorio, respecto al de ciencia; donde la ciencia no llega bien, el libro puede asegurar la administración correcta, la mecanicidad eficaz, de los sacramentos y, en su caso, la enseñanza-transmisión de la doctrina cristiana en sus enunciados fundamentales.

Pedro Vaz Gavião, obispo de Guarda (1496-1516), residió poco en su sede; no obstante, dotó a su diócesis de un cuerpo normativo muy completo, que promulgó en el sínodo celebrado el 12 de mayo de 1500. Según se indica en el proemio, en la elaboración de las sinodales se tienen en cuenta las promulgadas por sus antecesores en la sede, en cuanto a declararlas, añadirlas o corregirlas; por lo demás, en adelante, las únicas en vigor serán las promulgadas por él mismo con el acuerdo y consejo del cabildo y de la cle-

cordia e cinque sentidos. E o abade que isto nom tiver, avemollo por condenado em trezentos reaaes pera as obras da nossa see e nosso meirinho». El texto del sínodo de Braga puede verse en SH II, 166.

${ }^{194}$ SH II, 354: introducción de I. da Rosa Pereira al sínodo; 405-414: texto del catecismo.

195 SH II, 166.

196 SH II, 382: «E assi mandamos a todollos clerigos e capellães de nosso bispado que cartas de cura quiserem aver, que primeiro que lhes sejam dadas, quando vierem ante nós ou nosso vigairo pera serem examinados, tragam breviairo seu própio e assi o sumário acima decrarado que mandamos teer aos abades, e dar-lhe-am juramento aos Avangelhos se os ditos livros som seus, e jurando que som seus e achando-os idoniuos pera tal carreguo, e emtam lhe daram sua carta de cura, e doutra maneira nom». El texto del sínodo de Braga puede verse en SH II, 166. 
recía. Respecto de las constituciones anteriores a las que alude, no tenemos más noticias que las aportadas por este sínodo; para un periodo muy anterior tenemos una referencia genérica del obispo Rodrigo Fernandes (1249 -1267), en documento fechado en febrero de 1249, respecto a la celebración regular, anual, de sínodos: "Et quando uocati fueritis a nobis, semel in anno, ad sinodum...», que no nos basta para afirmar la celebración, de hecho, de sínodos en ese tiempo ${ }^{197}$.

El obispo Pedro Vaz Gavião se ocupa del saber clerical en la constitución número 46. Es una de las sinodales tomadas de sus predecesores y corregidas en algunos puntos.

De principio, pone en evidencia el incumplimiento de lo mandado por sus antecesores en cuanto a que los sacerdotes sepan cantar y lo necesario al oficio. La experiencia le enseña que muchos son ignorantes; y causan daño a las iglesias y escándalo al pueblo ${ }^{198}$.

En la parte dispositiva mantiene la parte sustantiva de la norma recibida y modifica los aspectos que, a su entender, la hicieron ineficaz. Así parece, por deducción lógica, pues, en realidad, de la norma anterior sólo se conoce, a través de la constitución que comento, la parte sustantiva, no la forma, ni las garantías de su cumplimiento, ni la parte penal; y tampoco se sabe si contenía o no parte penal, o si preveía alguna forma concreta de cumplimiento.

La parte sustantiva responde a que todos los sacerdotes y beneficiados aprendan bien el arte del canto y lo relativo al oficio. En cuanto al cumplimiento de esta norma, exceptúa a los mayores de cuarenta años, por viejos para aprender ${ }^{199}$; y concede un plazo de un año desde la publicación de las sinodales para el aprendizaje.

La pena a imponer será distinta según se trate de un curado o beneficiado o de un clérigo no beneficiado; al curado y al clérigo beneficiado que no cumplieren se les condenará a una multa de mil reales, a repartir por mitad entre el juez diocesano y la fábrica de la iglesia mayor, mientras que al no beneficiado se le condenará con la privación de los avíos para decir

197 SH II, 223-224: introducción de I. da RosA PereirA; 224-225: proemio.

P. B. GAMs, Series Episcoporum Ecclesiae Catbolicae, Graz, 1957, p. 100, aporta un dato interesante para valorar dicha referencia: el obispo Rodrigo Fernandes no entró en la sede de Guarda hasta el 27 de febrero de 1256, a siete años del documento citado, relativo a la concesión de exenciones a los beneficiados de Portalegre.

198 SH II, 249-250: «Sem embargo de ser por nossos predecessores mandado que todos os sacerdotes soubessem cantar e assim outras coisas que a seu oficio pertencem, achamos que o dito mandado houve poco efeito, porquanto ainda agora por experiência achamos muitos deles ignorantes em modo que deles sai mau exemplo e escândalo ao povo e as igrejas ainda por elo padecem detrimento".

199 Véanse los textos citados en las notas 88 y 89. 
misa ${ }^{200}$ y al castigo que el obispo estimare oportuno, a la vista de la magnitud de la culpa $a^{201}$.

En la condena anotada no se alude a la pena canónica. Puede que se dé por supuesta y sabida; pero creo, más bien, que no. Dada la ignorancia de los clérigos, no hay razones para suponer que éstos conocían las penas inherentes a su permanencia en la ignorancia. La razón es que eran penas ineficaces. ¿Cómo suspender del ejercicio de la cura de almas a todos los ignorantes? Era quedarse casi sin curados ${ }^{202}$.

Se imponen, por tanto, penas pecuniarias, que, cuando menos, tenían efectos materiales positivos y prácticos para la economía de la sede episcopal y de la diócesis, favoreciendo la construcción o mejora de la catedral y el sostenimiento del juez diocesano, por ejemplo. Este traslado desde penas canónicas espirituales a penas materiales es frecuente; y, en ocasiones, se indica la razón del cambio o de la añadidura de la pena material a la espiritual, cifrando la razón en la mayor eficacia de la pena pecuniaria.

\section{Castilla y León ${ }^{203}$}

Las diócesis, cuyos sínodos incluyo en este epígrafe, tienen en común su pertenencia política al reino de Castilla y León; por lo demás, su status jurídico es diverso. Tres eran diócesis exentas, sin metropolitano, dependientes directamente de Roma: Burgos, León y Oviedo; cuatro, Avila, Badajoz, Coria y Salamanca, eran diócesis sufragáneas de Santiago de Compostela; tres, Cuenca, Palencia y Segovia, lo eran de Toledo, sede primada de los reinos hispanos.

200 La parte penal es similar, en parte, a la del sínodo de Evora de 1466 del obispo Luis Pires (c. 39); y, en parte (en el hecho de la multa y su aplicación), a la de los sínodos de Porto de 1496 y de Braga de 1505 (cc. 36 y 34, respectivamente).

$201 \mathrm{SH}$ II, 250: «E querendo em todo prover, ordenamos e mandamos que todos os sacerdotes ou beneficiados que forem até idade de quarenta anos que da publicação desta a um ano saibam bem cantar por arte o que ao ofício da igreja pertence, e não cumprindo assim, condenamos cada um prior ou beneficiado em mil reaes, a metade para o meirinho e outra para as obras da nossa sé. E o que não fôr beneficiado não lhe seja mais pelos priores ou por aqueles que delo tiverem cárrego dado guisamento para dizer misa, além de o nós castigarmos se tanta negligência nele couber».

${ }^{202}$ El temor a quedarse sin curados hábiles obligó al obispo Luis Pires en el sínodo de Evora de 1467 a suspender la sentencia de excomunión contenida en la constitución 39 del sínodo celebrado el año anterior. Véase la nota 183.

${ }^{203}$ Juan Cándido de MATÍsS Y VICENTE, en el Extracto de su tesis doctoral, publicado bajo el título Normativa sinodal astur-leonesa anterior a Trento, Salamanca, 1987, pp. 29-34, recoge las normas sinodales relativas a la ciencia que debe poseer el clérigo en las diócesis enclavadas en el reino astur-leonés, con especial atención a las diócesis de León, Oviedo y Astorga. 
Esta diversidad de status jurídico es un elemento más a tener en cuenta a la hora de examinar y explicar la variedad de respuestas y de situaciones de las diócesis castellano-leonesas.

a) Primer periodo (1228-1322).

Para este primer periodo, dada la escasa actividad sinodal que conocemos en las diócesis reseñadas, sólo he hallado referencia expresa al tema de la ciencia clerical en el sínodo de León de 1303, siendo obispo Gonzalo Osorio (1301-1313).

Las quince últimas constituciones de este sínodo, de la número 25 a la número 39, forman un breve sacramental o instrucción sobre lo que deben saber los curados para administrar adecuadamente los sacramentos de la iglesia (bautismo, penitencia en los casos no reservados, eucaristía, extremaunción, matrimonio) o para dar lugar a su administración por el obispo (confirmación, penitencia en los casos reservados, orden).

Al tratar del sacramento del orden, en la constitución número 39, recoge la exigencia canónica mínima, en cuanto a ciencia, para que un clérigo menor pueda recibir una orden sagrada, exigencia que se concreta en saber bien leer y cantar.

En otro parágrafo de esta misma constitución 39 se exige a los rectores de las iglesias que tengan un clérigo (se supone menor), o un mozo (un monaguillo), que sepa leer y cantar, como ayudante para la misa y las horas canónicas ${ }^{204}$. Advierto en esta exigencia una modalidad a tener en cuenta. No se pide en este caso que el clérigo o mozo ayudante sepa bien leer y cantar, como es habitual cuando se refiere a los rectores, sino simplemente que sepa.

La preocupación por el saber de los curados se revela también en la constitución número 13 de dicho sínodo. Se contiene en ella una breve forma de visita para arcedianos y arciprestes, sobre quienes en la práctica descargaba el obispo la responsabilidad de la visita canónica en su doble vertiente, espiritual y material. Expone las trece preguntas-examen que debe hacer el arcediano; una de ellas, la decimotercera, se refiere a si los sacerdotes saben y dicen bien el canon de la misa, cómo realizan los signos, y si administran con toda corrección, con la materia y forma debidas, los sacramentos de la Iglesia ${ }^{205}$.

204 SH III, 281: «El septimo sacramento es orden sagrada, et desto deven saber los clerigos que nengun clerigo non se deve ordenar se non sopier bien leer et cantar... Item, cada rector aya al menos un clerigo o un moço que lo aiude a la missa et a las Horas, et que saba leer et cantar».

205 SH III, 266: «La xiii., examine los prestes, commo saben el canon de la missa, por que paravlas consagran, quando levantan, commo fazen los signos, por que paravlas baptizan et ministran los otros sacramentos». 
Cabe citar asimismo el sínodo de León de 1267 ó 1262. Aunque no hay en él una referencia explícita al tema, sí hay una referencia global.

En la constitución número 52 se intima a los arciprestes a que no presenten a la recepción de órdenes sagradas a clérigos que no sean dignos o que no tengan título beneficial ${ }^{206}$.

Es indudable que entre las cualidades que conforman la dignidad clerical, una es la posesión de la ciencia suficiente. De todas formas, hay que reconocer que este aspecto no se explicita en el texto, mientras que sí se explicita el requisito de tener título beneficial, al tiempo que el término digno parece tener aquí más conexión con la honestidad de vida que con la ciencia del clérigo. Quizás la explicación esté en que, siendo tan poco lo exigido, se le suponía a cualquier clérigo en grado bastante.

Yendo a más en esta línea de razonamiento, destaca el hecho de que en ninguno de los sínodos citados se denuncia la ignorancia de los clérigos como problema real de importancia. Así, en el sínodo de 1303, constitución número 32, se admite con naturalidad, sin hacer de ello mayor cuestión, que los curados pueden no saber hacer sermón, en cuyo caso se conforma con que digan lo que sepan o que encomienden el sermón a un fraile (a quien se le supone, al menos en principio, una formación teológica suficiente para ello), si lo hay a mano ${ }^{207}$.

\section{b) Segundo periodo (1322-1500)}

Durante el segundo periodo, la actividad sinodal en las diócesis enclavadas en Castilla y León, aunque irregular, es frecuente en su conjunto, sobre todo en el último tercio del siglo XIV y en la segunda mitad del XV; pero siguen siendo muchos los sínodos que no tocan el tema.

\section{1) Toledo}

Juan de Aragón, arzobispo de Toledo (1319-1328), reaccionó con prontitud a la llamada del legado Guillermo en el concilio de Valladolid de 1322 , reuniendo sínodos y concilios.

En el sínodo celebrado en Toledo el año 1323, en su primera constitu-

206 SH III, 248: «Otrosi, defendemos que nengun arcepreste, nen otro que tenga logar de arcepreste, non presente a ningun clerigo a las ordenes sagradas, se non fur digno o se non ovier titulo de beneficion.

207 SH III, 276: «Item, stablecemos que cada domingo enna missa prediquen los rectores, se sobieren o se acescier y algun frade; et se non sobieren fazer sermon, digan aquello que sobieren depoes del evangelio». 
ción, ofrece a sus curados una instrucción breve de la doctrina cristiana, que, conforme a lo establecido por el legado sabinense, deberían tener consigo, en romance y en latín, para instruir por ella a sus fieles en determinados días del año ${ }^{208}$.

En cuanto al tema del saber clerical propiamente dicho, se conforma con una alusión indirecta a la posible ignorancia de los rectores de las iglesias, ignorancia que es preciso evitar. Para ello, dispone, de acuerdo con los cánones, que no se administre ningún beneficio curado sin la institución diocesana, con la que, en teoría, quedaba garantizada la idoneidad, en ciencia y en los demás requisitos, del instituido.

Esta norma se da para el ámbito metropolitano, no sólo para el diocesano, pues se establece en el concilio provincial de Toledo del año $1324^{209}$. En el mismo concilio se decide asumir en bloque las constituciones legatinas de $1322^{210}$.

Este último dato ayuda a explicar que algunos temas, incluso de gran y reconocida importancia, como el de la ciencia clerical, no aparezcan de modo regular en los sínodos; en éstos se atiende más fácilmente, por lo general, a cuestiones cotidianas y materiales, que surgen del vivir de cada día.

La problemática de la ignorancia clerical, sólo cuando se asume como grave, conforme al criterio y la sensibilidad de cada obispo, se trae a sínodo; entonces, se recuerdan en él, con mayor o menor detalle, muchas veces sólo en substancia, las normas canónicas al respecto y se intima su cumplimiento.

En el concilio provincial de Toledo de 1339, siendo arzobispo Gil de Albornoz (1338-1350), en las constituciones números 2 y 3 , se urge el cumplimiento de lo establecido por el legado Guillermo sobre la peritia litterarum de los curados, que se concreta, de una parte, en la exigencia de saber hablar latín para ser instituido clérigo, sin posibilidad de que los obispos dispensen de este requisito, salvo en casos de fuerza mayor, como sería el de no hallar clérigo letrado disponible; y, de otra parte, se concreta

208 c. $<1>$ (Sánchez Herrero 174-176): «Summa totius discipline christiane, ut ait Augustinus, est in fide, et moribus. Ideoque volentes...».

c. $<5>$ (Sánchez Herrero 176): «Statutum super publicandis populo certis diebus articulis fidei... de quibus supra diseruimus, et eiusdem in vulgari et latina lingua habendis, pridem per dominum sabinum apostolice Sedis legatum editum in virtute obedientie, tanquam saluti animarum necesarium precipimus observandum».

209 c. <4> (Sánchez Herrero 187): «Inter episcopales solicitudines ... ne astucia satane eas dicipiat propter rectorum ignorantiam vel defectum... nullus in curato beneficio administret donec cum eo diocesanum episcopum institutione auctorizabili fuerit institutus, seu cura commissa fuerit animarum».

210 Al final del proemio (Sánchez Herrero 185): «Precipimus constitutiones per dictum dominum legatum editas in concilio per eum apud Valleoleti celebrato, cum infrascriptis per nos in presenti concilio additis observari». 
en la obligación, compartida por obispo y cabildo, de enviar clérigos de las catedrales y de las colegiatas a los estudios generales de teología, derecho canónico y artes liberales, en la proporción de al menos uno por cada diez residentes ${ }^{211}$.

En cuanto al primer punto, no hay comentario alguno sobre el grado de su cumplimiento en las diversas diócesis de la metrópoli toledana. En cuanto al segundo punto, se denuncia que algunos, obispos/cabildos, son remisos en su observancia, lo que, a sensu contrario, significaría que algunos otros cumplían con regularidad la norma. A los «remisos» da un plazo de seis meses para atenerse a lo establecido; si, pasado el plazo, no hubieran enviado a nadie, el arzobispo asumirá, por esa vez, la responsabilidad de elegirlos y enviarlos ${ }^{212}$.

Se trata de la misma medida tomada por Bernardo Oliver en el concilio provincial de Tarragona de 1277 y después por Jimeno de Luna en el de 1318 y Juan de Aragón en el Corpus tarraconense de 1330.

Desde 1339 hasta bien entrada la segunda mitad del siglo XV, es decir, durante siglo y medio, no disponemos de nueva documentación de la diócesis toledana sobre el tema.

Del arzobispo Blas Fernández de Toledo (1353-1362), se podía esperar alguna indicación, dada su trayectoria anterior como obispo de Palencia (1343-1353), donde celebró varios sínodos; y, aunque en ninguno trató expresamente del tema de la ciencia clerical, en dos de ellos, los de 1345 y 1346, apunta algo cuando hace referencia al oficio del curado de enseñar al pueblo la doctrina, estableciendo que todos los curados tengan, al menos en romance, el libro de la doctrina cristiana, con el que informen de ella a los fieles $^{213}$.

211 c. $<2>$ (Sánchez Herrero 202): «Quia in constitutione recolende memorie domini fratris Guillielmi... statutum quod nullus clericus ad sacros ordines promoveatur nisi saltem litteraliter sciat loqui; pari ratione, sacro approbante Concilio, statuimus quod quandiu inveniatur clericus qui litteraliter sciat loqui, vel promotus ad sacerdotium qui possit et velit in beneficio, cui cura imminet animarum, institui, Episcopis dispensandi ut is promoveatur ad sacros ordines et ad benefficium cum cura, qui litteraliter nescit loqui... sit penitus interdicta».

c.<3> (Sánchez Herrero 202-203): «In alia etiam constitutione eiusdem legati... statutum est ut in qualibet Cathedrali vel Collegiata... iudicio Episcopi vel prelati et Capituli, saltem unus ex decem de residentibus assumatur, qui ad studia generalia Theologie et iuris Canonici ac liberalium artium accedere compellantur".

212 c. $<3>$ (Sánchez Herrero 203): "Quia nonnulli in executione huiusmodi constitutionis sunt remissi... statuimus ut, si infra sex mensium spatium iuxta constitutionem ipsam ad studia litterarum mittere distulerint, ex tunc ea vice potestas eligendi et mittendi ad nos et successores nostros totaliter devolvatur, consuetudinis vel statuti illius ecclesie obstaculo non obstante».

213 Sínodo de 1345, c.<2> (San Martín 140-142): «Rubrica: De officio ordinarii. Quoniam... curati ecclesiarum preter curam quam habent tenentur subditos... instruere... 
La frase "al menos en romance" nos indica que el latín estaba ya en declive entre los clérigos palentinos, de modo que el obispo se conforma con que tengan el libro de la doctrina sólo en romance.

Durante el gobierno de la diócesis primada, Blas Fernández de Toledo se mantiene en la misma línea, sin abordar directamente la problemática de la ciencia clerical. Reunió dos sínodos, en 1354 y $1356^{214}$, y un concilio provincial en 1355.

Destacan en ellos las referencias a la obligatoriedad de las constituciones sinodales, provinciales y legatinas, suavizando el peso de su transgresión; determina que, en adelante, tanto unas como otras, obligarán sólo a pena, no a culpa ${ }^{215}$. En el corpus sinodal de 1356 recoge y asume numerosas constituciones de Juan de Aragón ${ }^{216}$; y, entre ellas, las relativas a la instrucción de la doctrina, que los curados deberán predicar al pueblo en lengua romance ${ }^{217}$.

El concilio provincial toledano de 1473, celebrado en Aranda, iglesia de la diócesis de Osma, sufragánea de Toledo, siendo arzobispo Alfonso Carrillo (1446-1482), afronta el problema de la ciencia clerical con referencia a la exigencia mínima para el clérigo curado, siguiendo de cerca los dictámenes del concilio de Valladolid de $1322^{218}$.

El capítulo tercero toca varios aspectos del tema en cuestión: la importancia del saber clerical en general; el requisito canónico de saber latín para recibir órdenes sagradas; la ineficacia del sistema del examen de idoneidad y cómo mejorarlo; las penas a los infractores de la normativa.

presenti constitutione duximus statuendum ut omnes... curati habeant in scriptis, recipiant atque leuent, saltem in uulgari, precepta decalogi, articulos fidei, sacramenta ecclesie, species uirtutum et uiçiorum, opera misericordie spiritualia et temporalia, sub pena uiginti morabetinorum et publicent ea in singulis dominicis quadragesime et aduentus». En el sínodo de 1346, se recuerda y se refuerza la obligatoriedad de la norma anterior (Ibid. 158-160).

J. San Martín nos ofrece, junto al texto latino, una traducción castellana, según manuscritos que fecha en el mismo siglo XIV.

${ }^{214}$ En este sínodo publicó un corpus sinodal, en el que recoge sus propias constituciones y una selección de las sinodales de sus predecesores. Cf. Sánchez Herrero 52.

${ }^{215}$ Cf. los textos correspondientes en Sánchez Herrero 217, 220-221, 239.

${ }^{216}$ De un total de cuarenta y siete, treinta y tres (el $\left.70 \%\right)$ son del arzobispo Juan de Aragón.

${ }^{217} \mathrm{La}$ instructio se recoge en cinco constituciones, cc.2-6 (Sánchez Herrero 224-226). Su publicación se ordena en la c.12 (Ibid. 228): «Statuimus ut Constitutiones felicis recordationis Domini Iohannis predecesoris nostri super articulis fidei... olim ab ipso predecesore edite, que superius sunt inserte... in festivitatibus Natalis, Resurrectionis, Pentecosthes, Asumptionis beate Marie et prima dominica adventus, et prima dominica quadragessime in eisdem ecclesiis populo ibidem tunc ad Missarum sollepnia venienti in lingua vulgari alta voce de cetero publicentur".

${ }^{218}$ c.9. $<2>$ (Tejada III, 487). Texto transcrito en la nota 25. 
Como premisa se argumenta que la encomienda de la cura de almas se debe conferir a gente entendida, que comprenda la inmensidad de la fe y que sepa distinguir entre lepra y lepra. Así, pues, en adelante, no se promoverá a órdenes sagradas a nadie que no sepa hablar latín, dado que con gran frecuencia, sea por ignorancia, descuido o malicia, los encargados por los obispos de examinar a los candidatos presentan como dignos e idóneos a personas indoctas y analfabetas; y en estas condiciones reciben las órdenes sagradas o mayores ${ }^{219}$.

Con objeto de asegurar la seriedad del examen, se establecen algunos cambios, que no afectan al contenido ni a la forma del examen, sino a las personas examinadoras. En primer lugar, se recomienda a los obispos que sean ellos mismos quienes realicen el examen; y, en caso de no poder, que designen para dicho cometido a dos varones (clérigos) idóneos en ciencia y virtud, imponiéndoles bajo pena de excomunión el cumplimiento fiel del encargo 220 .

Las penas alcanzan teóricamente a conferentes, examinadores y recipientes. Además de otras penas previstas en los cánones, los conferentes quedan suspendidos de la ejecución de cualesquiera órdenes sagradas, los examinadores, del oficio y beneficio y los indignamente promovidos, de la ejecución de la orden así recibida; todos ellos por el periodo de un año ${ }^{221}$.

Pero, toda esta normativa, de aparente fortaleza, se acompaña de una excepción, en parte lógica, si tenemos en cuenta el grado de discrecionalidad que el derecho canónico admite en el ejercicio de la potestad episcopal y que, en el caso, parece, más bien, una escapatoria por donde se diluye el vigor de la norma: el obispo, a quien compete conferir la orden, o permitir

219 Sánchez Herrero 285: «Agri Dominici cultura non est indignis operariis committenda, sed illi dumtaxat conducendi sunt in Domo Domini qui secundum Apostolum sciant quae sit longitudo, latitudo, sublimitas et profundum... ideoque... statuimus, nullum ad sacros ordines de caetero promovendum, nisi sciat Latinaliter loqui; quia tamen plerumque contingit ob defectum, negligentiam vel dolum eorum, quibus ab Episcopis Ordinum examinatio committitur, quod indocti et omnino ignari... ut digni et idonei, praedictis Episcopis praesentantur, sicque per eos ad sacros ordines promoventur...».

220 Sánchez Herrero 285: «Nos... Episcopos... in virtute sanctae obedientiae monemus, quatenus si... examini personaliter non adfuerint, duos saltem viros idoneos scientia et moribus approbatos deputent, quibus officium examinationis pariter committant iniungendo eisdem sub excommunicationis poena, ut onus hoc sibi creditum fideliter exsequantur».

221 Sánchez Herrero 285-286: «Praelati autem sacrum ordinem per se ipsos contra praedictam prohibitionem non scientibus loqui latinaliter conferentes, praeter poenas a jure statutas, a quorumcumque sacrorum ordinum, quos tali contulerint, ipsumque indigne promotum ab exsecutione suscepti ordinis, examinatores vero in praemissis culpabiles, ab officio et beneficio, per annum noverint se suspensos».

El concilio vallisoletano de 1322 no incluye a los examinadores, al no considerar su culpabilidad, centrando toda la responsabilidad en los prelados conferentes y en los promovidos. 
que sea conferida por otro, puede dispensar de las exigencias señaladas al candidato, si estima que hay una causa razonablemente necesaria; con lo cual la pena, al menos para los conferentes, cuando lo sean los obispos propios, será letra muerta y sólo tendrá aplicación, en su caso, respecto a quienes el obispo en cuestión haga responsables ${ }^{222}$.

El capítulo décimo complementa al anteriormente glosado, con una atención especial a los curados y a los canónigos y dignidades. Se determina en él que lo dispuesto en el capítulo tercero sobre el conocimiento del latín para recibir órdenes sagradas se aplique con el máximo rigor en la colación de las iglesias parroquiales, así como de las canonjías y dignidades de las iglesias metropolitanas y catedralicias; si bien, en el caso de canonjías y dignidades, los obispos pueden dispensar por una causa que estimen ser de necesidad evidente ${ }^{223}$.

De la redacción del texto se deduciría que la posibilidad de dispensa no alcanza a los curados, lo cual, a su vez, no parece conformarse con lo que acabamos de indicar al glosar el capítulo tercero, en el que se prevé la posibilidad de dispensa de forma generalizada para los promovidos a órdenes sagradas.

Teniendo en cuenta ambas disposiciones, me inclino a pensar que los padres conciliares (o, cuando menos, el arzobispo presidente del concilio) tienen la voluntad de excluir de la posibilidad de ser dispensados discrecionalmente a los que han de ser promovidos a la cura de almas en iglesias parroquiales, pero esa voluntad no se concreta con la suficiente claridad y determinación, dejando así la puerta abierta a que los obispos usen, también con los curados, de su facultad de dispensar discrecionalmente, es decir, cuando, a su juicio, hubiere una causa razonable.

222 Sánchez Herrero 286: «Nisi ex causa rationabili et multum necessaria, ut in dicta constitutione continetur, cum eisdem promotis Praelati viderint dispensandum».

La constitución aquí aludida es la número 9 del concilio de Valladolid de 1322, del que la toma casi literalmente. Gil de Albornoz, al hacerse eco de esta constitución, la interpreta en sentido restrictivo, al precisar que la facultad de dispensar la tienen los obispos sólo cuando no hallan un clérigo idóneo para la encomienda de la cura; hecho éste, que constituiría la única causa razonable y muy necesaria aludida en la norma legatina, sin dejar esta argumentación a la discrecionalidad de cada obispo.

223 Sánchez Herrero 290: «Cum in Constitutione nostra quae incipit: Agri Dominici contineatur nullum ad sacros ordines promovendum nisi latinaliter sciat loqui, id etiam summa observantia cavendum est in collationibus Parochialium Ecclesiarum. Nam cum ars artium sit regimen animarum, pari ratione, sacro approbante Concilio, statuimus, nullum de parochiali Ecclesia debere provideri, nisi saltem latinaliter sciat loqui. Attendentes etiam, quod quanto crescunt dona, tanto etiam rationes crescunt donorum, eandem constitutionem ad Canonicos tam Metropolitanarum quam Cathedralium nostrae Provinciae Ecclesiarum et ad maiores post canonicatus earundem ecclesiarum dignitates exstendi, tenore praesentium, eodem approbante Concilio, volumus et inhibemus, nisi ex causa multum evidenti et necessaria cum ipsis Canonicis Praelati viderint dispensandum». 
No era fácil, por otra parte, que los obispos se avinieran, sin objección alguna, a una limitación de su potestad discrecional.

Unos años más tarde, en 1480, Alfonso Carrillo celebra su primer sínodo diocesano. No se recogen en él, respecto a nuestro tema, las disposiciones provinciales de siete años antes, que debemos suponer en vigor; $y$ tampoco hay queja o denuncia de ignorancia respecto de los curados.

En este sínodo Alfonso Carrillo sale al paso de una corruptela que invalidaba en una buena proporción la norma de poner al frente de iglesias con cura de almas o de beneficios servideros a clérigos dignos: los titulares de la cura o servicio conseguían permiso del arzobispo para ausentarse y ponían en su lugar a "capellanes de poco saber e de non buenas costumbres".

Para atajar este abuso, dispone que, en adelante, los designados como sustitutos, previamente a servir la cura o los beneficios, se sometan a un examen ante el provisor del arzobispo o ante alguno de los vicarios generales en Toledo y Alcalá o ante los examinadores nombrados para el caso por el propio arzobispo. El examen, por lo que se refiere a ciencia, versará sobre lectura, canto y gramática.

Como garantía de cumplimiento y superación de la prueba, dichos capellanes no podrán ser admitidos a servir sin presentación previa del certificado del examen y de la licencia del servicio ${ }^{224}$.

La medida constituye, sin duda, un paso importante para asegurar la suficiencia de saberes de los encargados de la cura de almas.

Además, el sínodo de 1480 insiste en la enseñanza de la doctrina a los fieles de dos maneras. De una parte, mediante la predicación en las misas dominicales de la cuaresma, de Septuagésima a Pasión, por los propios curas y rectores parroquiales; de otra, mediante la fijación de una tabla de la doctrina «en lugar publico eminente, donde cualquier persona la pueda leer e se informar de lo en ella contenido». En la tabla estarán escritos los artículos de la fe, los sacramentos, los mandamientos del decálogo, los pecados mortales, las obras de misericordia, las virtudes, los dones del Espíritu Santo, los cinco sentidos y los casos reservados al papa y al obispo ${ }^{225}$.

224 c. $<15>$ (Sánchez Herrero 313): «E por que acaesce que los curas e los que tienen beneficios servideros se absentan dellos con nuestra licencia... poniendo capellanes de poco saber e de non buenas costumbres... hordenamos... presenten... personas suficientes de honestidad y buena vida, los cuales ante que sirvan sean examinados por nuestro provisor o por alguno de nuestros Vicarios Generales de Toledo o de Alcalá o por los examinadores que para esto por Nos seran diputados... de honestidad y de leer y cantar e construir e... muestren por escriptura como son examinados y traen licencia para servir los dichos beneficios".

${ }^{225}$ c. $<1>$ (Sánchez Herrero 303): «Hordenamos que los dichos curas e retores perrochiales... de aqui a tres meses primeros siguientes fagan poner en cada una de sus iglesias una tabla en que estén escriptos en pergamino todos los articulos... sacramentos... colgada de un clavo en lugar publico eminente... e hordenamos que cada uno de los dichos curas e retores 
En cuanto a la enseñanza, el sínodo pone un cuidado especial en la instrucción de los niños.

La responsabilidad recae primero en los mismos padres, no en cuanto que tengan que ser ellos maestros de sus hijos, sino en cuanto que se deben preocupar de que se les enseñe.

Subsidiariamente, y a falta de maestros, defecto que la realidad pone en evidencia, la responsabilidad llega a los curados, quienes deberán ayudarse de un clérigo o sacristán, bueno y docto, y que "quiera mostrar leer e escrevir e cantar a cualesquier personas en especial a fijos de sus perrochianos", al que pagarán un salario digno, de modo que si las facultades de la parroquia no alcanzaran, se recurrirá al arzobispo 226 .

El arzobispo Francisco Jiménez de Cisneros (1495-1517), en sus dos sínodos, celebrados en Alcalá (1497) y Talavera (1498), no hace referencia directa a la ciencia clerical. Parece dar por supuesto que los curados poseen los conocimientos mínimos suficientes; su preocupación está puesta en que los curados, por sí mismos o por otros, enseñen la doctrina, especialmente a los niños menores de doce años (catequesis dominical tras el canto de la Salve) $)^{227}$, y declaren el evangelio "todos los domingos despues de la ofrenda ... a lo menos literalmente» 228 .

Esta tendencia a ocuparse de los curados preferentemente como maestros y predicadores de la doctrina la notamos en otros sínodos de diócesis sufragáneas de Toledo de los siglos XIV y XV, y de una forma progresiva. Ya

perroquiales por si e por sus lugares tenientes sean tenidos e obligados de publicar e declarar todo lo contenido en la dicha tabla a sus perroquianos en la misa despues del ofrenda en el primer domingo despues que levaren estas constituciones, e asi mismo en todos los domingos despues de la septuagesima hasta el domingo de la pasion".

226 c. $<5>$ (Sánchez Herrero 305): «Entre las otras cosas que los Padres son tenidos a faser por sus hijos... enseñar las cosas que son nescesarias... e porque conoscemos por experiencia que por defecto de maestros e de enseñadores... estatuimos que en cada una de las Iglesias Perrochiales de nuestro Arçobispado, donde oviere pueblo, el cura tenga consigo otro clerigo o sacristan, persona de saber e honesta, que sepa e pueda e quiera mostrar leer e escrivir e cantar... e señaladamente les muestren los diez mandamientos, el pater noster, el ave maria, el credo y la salve regina y la confesion general, et todo lo que esta en la Cartilla de las Iglesias... e en las iglesias que no fuere assi proveydo de salario suficiente, recurran a nos".

227 c. $<4>$ (Sánchez Herrero 344-345). Coincide en lo sustancial con lo dispuesto por su antecesor Alfonso Carrillo. Una diferencia formal a destacar es que no se habla ya, aunque tampoco se descarta abiertamente, de tener un clérigo o sacristán como maestro, a la vez que catequista, institucionalizado y con salario suficiente; probablemente, porque las iglesias no podían sostenerlo. Cisneros admite que los curados pueden encargar la enseñanza a otros, sin indicación de que deban o puedan ser asalariados o recompensados de alguna manera; pero les exige a los curados que estén presentes durante la enseñanza.

${ }^{228}$ c. $<5>$ (Sánchez Herrero 345). 
aludí anteriormente a las disposiciones de Blas Fernández de Toledo, siendo obispo de Palencia, en los sínodos de 1345 y $1346^{229}$.

Asimismo, Diego de Roeles, obispo de Avila (1378-1394), en el sínodo celebrado en Bonilla el año $1384^{230}$, y Lope Barrientos, obispo de Segovia (1438-1441), de Avila (1441-1445) y de Cuenca (1445-1469), en el sínodo celebrado en Cuenca el año $1446^{231}$, se interesan directamente del cumplimiento del deber de los clérigos curados de enseñar la doctrina que ellos mismos deben ser los primeros en conocer; pero nada nos dicen sobre la situación de la ciencia clerical en sus diócesis, ni sobre las exigencias mínimas canónicas, sin que de este silencio podamos deducir que dichos obispos estaban satisfechos de la cultura de sus clérigos.

Lo que parece claro es que en estos sínodos la ciencia clerical no estuvo presente como problema transcendente sobre el que tomar decisiones.

\section{2) Segovia.}

El obispo Pedro de Cuéllar (1320-), «inmerso de lleno en el clima reformista imperado en la Iglesia universal desde Roma y a partir de los días lateranenses ${ }^{232}$, se hizo eco con prontitud de la llamada legatina, secundando a su metropolitano Juan de Aragón, con quien se vio, probablemente, en el concilio provincial toledano de 1324.

En el sínodo que celebró en Cuéllar el año 1325 promulgó un cuaderno de la doctrina, a modo de libro sinodal, en lengua vulgar, "para alumbramiento de los dichos simples clérigos que non lo entienden así como es dicho e era menester ${ }^{233}$. En este cuaderno son constantes las alusiones a la

229 Véase la nota 213.

230 c. $<1>$ (Sobrino Chomón 455): «Establescemos e ordenamos que estas dichas ordenaciones sobre los artículos de la fe e de los mandamientos... en cada domingo del avento e en cada domingo de la cuaresma... cada clérigo curado de la cibdad e del obispado de Avila... cuando viniere el pueblo a la misa lo deba decir públicamente a alta voz».

231 « $<\mathrm{O}>$ trosi, por quanto la notiçia dela fe catholica es nescesaria... mandamos alos dichos clerigos curados, so pena de suspension de ofiçio e de benefitio que, cada domingo dela quaresma declaren e publiquen alos pueblos a ellos cometidos los articulos dela fe e mandamientos dela ley e sacramentos dela iglesia e espeçies de viçios e virtudes dellas».

Mi agradecimiento a los doctores Antonio García y García y Francisco Cantelar Rodríguez, que me han facilitado el texto aquí transcrito, en una fotocopia del texto manuscrito a utilizar en la edición del Synodicon Hispanum, en la que figuran las observaciones y la puntuación del Dr. Francisco Cantelar Rodríguez.

Lope de Barrientos asume como propio, en los sínodos de Turégano (1440) y de Cuenca (1446), el texto castellano del liber synodalis de Gonzalo de Alba, en el que se contiene la exigencia de saberes de los clérigos curados. Véase la nota 248.

232 Martín-Linage 47.

233 Ibid. 169. 
escasez de conocimientos de los clérigos segovianos, como anotan MartínLinage ${ }^{234}$.

Siglo y medio después, el obispo Juan Arias Dávila (1461-1497), en el sínodo celebrado en Aguilafuente el año 1472, encara el tema de la ciencia clerical como problema urgente. Lo expone y regula en cuatro apartados lógicos: planteamiento de la cuestión, denuncia de la situación, disposición sustantiva y disposición penal.

En primer lugar, destaca la importancia de la ciencia y, a sensu contrario, la peligrosidad de la ignorancia en general, y de modo especial en los eclesiásticos, a quienes corresponde enseñar a los demás ${ }^{235}$.

En segundo lugar, describe la situación de ignorancia, rayana en el analfabetismo, en la que se hallan muchos clérigos de órdenes sagradas. El obispo afirma conocer esta situación "por vista e por examinacion e por cierta sabiduria»; asegura, además, que muchos de ellos ya han sido requeridos y amonestados, y aun castigados, sin fruto alguno ${ }^{236}$.

A continuación, establece, de acuerdo con los derechos y los cánones, que todos los clérigos de órdenes sagradas, que sean ignorantes, se dispongan a aprender en un plazo de cuatro meses, a contar desde el día de la fecha de la misma constitución, de su promulgación. El tiempo de estudio se fija en un periodo continuo de cuatro años, a partir de pasados los cuatro meses.

La norma afecta igualmente a aquellos clérigos que se ordenen in sacris en el futuro. Para éstos, el plazo de cuatro meses y cuatro años se contará a partir del día en el que adquieran la posesión pacífica de sus dignidades, canonjías, raciones o beneficios, es decir, a los tres meses de la toma de posesión de hecho ${ }^{237}$.

234 Ibid. 207.

${ }^{235}$ c.4 (Aguilafuente, fol. $<17 \mathrm{v}>$ ): « $<$ P > rudente e ydoneo de conueniente sciencia segund regla del apostol deue ser el que es llamado enla suerte del sennor para militar enla milicia clerical ca la ynorancia enlas otras personas es dannosa e enlos eclesiasticos es muy peligrosa por que con su enxemplo e sciencia e dotrina han de ensennar alos otros».

${ }^{236}$ Ibid., fols. $<17 \mathrm{v}-18 \mathrm{r}>$ : «E por quanto somos certificado... que muchos delos beneficiados de la nuestra iglesia cathedral e otros clerigos curados e non curados ordenados de ordenes sacras del dicho nuestro obispado son tan ynorantes e insuficientes que non saben leer nin cantar nin son gramaticos nin saben la construcion e lengua latina nin entienden nin saben entender lo que leen como deuien... e como quier que muchos... han seydo por nos begnina e caritatiuamente requeridos e amonestados e aun despues con cominacion e aposicion de algunas penas que quesiesen aprender... non lo han querido nin quieren fazer...».

237 Ibid., fol. <18 r - v >: «E conformando nos con aquello que los derechos e sacros canones quieren e disponen... mandamos que todos e qualesquier beneficiados... curas e rectores que cargo tienen de animas e otros cualesquier clerigos ordenados in sacris... que non saben cantar nin construir... dentro de quatro meses primeros siguientes de oy dia de la data desta nuestra constitucion lo comiencen aprender e lo continuen sin interualo... quatro annos 
$\mathrm{Si}$, una vez agotados los plazos, los clérigos interesados no superasen el examen ante el obispo, si son beneficiados, perderán los frutos y rentas de sus beneficios; y, si no lo son, quedarán suspensos de las órdenes recibidas. Así permanecerán unos y otros hasta tanto no superen el examen de idoneidad; pero si los hallados indoctos probaren su estancia y residencia en el estudio de forma continuada, es decir diez meses por año, haciendo lo posible de su parte por aprender, no se les impondrán las penas antedichas sino que, en su lugar, se les obligará a continuar por un año más en el estudio general para que pongan nuevamente todo su esfuerzo en aprender; y, si no lo hicieren así, entonces caerán en las penas citadas $^{238}$.

A pesar del tiempo concedido para el aprendizaje en el estudio general -cuatro o cinco años-, el objetivo prioritario del obispo y del sínodo no es, aunque tampoco se excluya, el perfeccionamiento en los saberes teológicos, jurídicos y de artes liberales; lo que se exige saber después de esos cuatro o cinco cursos académicos, se reduce al mínimo requerible para un ordenado in sacris y, con mayor razón, para un clérigo curado: leer, cantar y gramática, con una atención especial a la lengua latina. Por otra parte, cabe destacar que no se tienen en cuenta la vejez y la debilidad mental, al menos no aparecen en el texto sinodal, como motivo de dispensa; tiene, no obstante, una atención con los menos dotados, a los que concede un año más de tiempo para el aprendizaje.

\section{3) Avila}

El obispo Alfonso Fonseca (1469-1485) reúne sínodo el año 1481 y

primeros siguientes despues delos dichos quatro meses... e en quanto toca alos dichos... clerigos in sacris que de oy en adelante enlos tiempos uenideros fueren... mandamos que los dichos terminos les coran e les sean contados desde el dia que ouieren la posesion pacifica delas dignidades... e beneficios curados que ouieren... la qual dicha posesyon se entienda ser pacifica sy touieren... sus beneficios por tres meses sin pleyto».

${ }^{238} \mathrm{Ibid}$., fols. < $19 \mathrm{r}-20 \mathrm{r}>$ : ${ }_{\mathrm{E}} \mathrm{si}$... non lo fizieren... los dichos curas e rectores pierdan los frutos delos dichos sus beneficios curados... e los que non fueren beneficiados enel dicho nuestro obispado sean suspensos por el mesmo fecho delas dichas ordenes sacras... las quales dichas penas... mandamos que duren... fasta tanto que por la dicha examinacion sean fallados habiles e suficientes enlas cosas suso dichas... Pero queremos e mandamos que sy al tyempo dela dicha examinacion los tales beneficiados que ansi fueren fallados inhabiles prouaren $e$ mostraren como continuaron los dichos quatro annos en estudio general estando e residiendo enel tal estudio continuadamente diez meses de cada uno delos dichos annos e fizieron su poder e diligencia en aprender... que non ayan logar contra ellos las dichas penas nin alguna dellas, pero que sean tenidos e obligados a estar e continuar enel dicho estudio general otro anno primero adelante siguiente faziendo su poder... en otra manera que dende adelante cayan enlas dichas penas e en cada una dellas». 
publica un libro de constituciones, "libro llamado signodal" 239 . Respecto del tema que aquí interesa, sus determinaciones vienen a coincidir, salvo variantes de detalle, con las del sinodal de Aguilafuente de 1472, que acabo de glosar; o Alfonso Fonseca las toma de Juan Arias Dávila, o uno y otro de una fuente común, que respetan totalmente en lo substancial.

Para no repetirme de forma innecesaria, señalaré sólo aquellos detalles en que difieren.

Alfonso Fonseca no aplica la obligación de estudiar a todos los beneficiados ignorantes en general; tiene en cuenta la excepción de la edad, y enmarca la obligación entre los 10 y los 35 años ${ }^{240}$.

Un detalle diferencial más está en la duración del año académico o, quizá mejor, en el tiempo continuado, por año, que el beneficiado debe residir en el estudio dedicado al aprendizaje. En el sínodo de Aguilafuente se fija en diez meses, mientras que en el de Avila se fija en ocho meses ${ }^{241}$.

Otra diferencia entre ambos es que Arias Dávila sólo menciona el estudio general, al que parece hacer referencia exclusiva; sin embargo, Alfonso Fonseca habla de poder residir en estudio general o en estudio especial, diferenciando estos dos tipos o especies de centros de enseñanza para eclesiásticos ${ }^{242}$.

Además, Alfonso Fonseca reserva un trato muy especial para los beneficiados de la iglesia catedral, detalle que no se halla en el sínodo de Arias Dávila. Dichos beneficiados, sobre los cuatro años normales, podrán continuar estudiando cuatro años más, si lo desean y consta de su habilidad en el aprendizaje $e^{243}$. Evidentemente, aquí se trata del perfeccionamiento en los

239 En el manuscrito utilizado, Madrid BN 8876, se emplea varias veces la denominación de libro sinodal; por ejemplo, en los folios I r, $11 \mathrm{v}, 17 \mathrm{v}$.

240 c.2.1.1 (fol. $40 \mathrm{v}-41 \mathrm{r}$ ): «Sta<tuimos> e ma<ndamos> que qual quier cura e rector o otro qual quier clerigo beneficiado de todo nuestro obispado que fuere mayor de hedad de diez annos e menor de treynta e cinco annos que non sabe cantar nin construyr...».

241 Ibid., fol. $41 \mathrm{r}$ : «... lo comiencen a aprender e lo continuen sin enterualo alo menos por ocho meses de cada vn anno».

Hay que anotar que Arias Dávila habla, en realidad, de residir continuadamente durante diez meses en el estudio, y Alfonso Fonseca se refiere directamnente a ocho meses continuados de estudio.

${ }^{242}$ Ibid., fols. $42 \mathrm{v}-43 \mathrm{r}$ : "Pero queremos e mandamos que si al tienpo dela dicha examinacion los tales beneficiados que asi fueren hallados inabiles prouaren e mostraren commo continuaron los dichos quatro annos en estudio general o especial estando e residiendo enel tal estudio oyendo sus liciones continuadamente al menos ocho meses...".

243 Ibid., fol. 43 r-v: «Otrosi poque los beneficiados de nuestra iglesia cathedral que ansi ignorantes se fallaren ayan mayor fauor... mandamos que assi los quatro annos suso dichos commo quatro otros despues si quisieren proseguir su estudio constando de su abilidad e cresciendo e aprouechando enla sciencia segund que por nos o por nuestros successores con consejo de nuestro dean e cabildo sera juzgado ayan despues de su residencia fecha la meytad delos frutos dela prebenda o beneficio». 
estudios eclesiásticos, no ya de la adquisición de los conocimientos mínimos exigibles.

Por otra parte, Alfonso Fonseca recoge la norma relativa a que ningún clérigo menor se haga promover a las órdenes sagradas sin saber hablar bien latín ${ }^{244}$.

\section{4) Salamanca}

El primer sínodo salmantino del que se conserva texto es el de 1396, siendo obispo Diego de Anaya y Maldonado (1392-1407). No trata directamente del tema de la ciencia clerical, pero sí hace algunas alusiones ocasionales al mismo en tres constituciones: primera, cuarta y sexta.

En la primera constitución se habla de la obligación de los sacerdotes de enseñar la doctrina y se denuncia que algunos no la cumplen porque ignoran la doctrina, no la saben de memoria y no tienen un cuaderno de ella. El remedio que se prevé en la parte dispositiva no va más allá de lo inmediatamente práctico: a los clérigos curas se les facilitará un cuaderno de la doctrina, que cada uno hará copiar en pergamino, y por dicho cuaderno mostrará la doctrina a sus fieles ${ }^{245}$.

En la constitución cuarta, que trata de los clérigos peregrinos, se hace referencia a la necesidad de obtener licencia especial del prelado, del obispo en nuestro caso, «aun para venir al Estudio»; se refiere aquí al estudio salmantino ${ }^{246}$.

Del contexto se puede deducir que en Salamanca había muchos clérigos "peregrinos», en el sentido peyorativo de vagos, errantes, procedentes de otros obispados, sin tener carta de licencia de sus prelados; y, al menos parte de ellos, pretendían justificar su estancia por razón del estudio. El sínodo les recuerda que también ellos necesitan licencia de su prelado.

244 Ibid., fol. 43 v: «Otro si eadem signodo aprobante statuimos e mandamos que ningund clerigo sea osado de se promouer ad sacros ordines sin primera mente saber fablar latin conpetente mente en otra manera por la presente lo suspendemos ab ex $<e>$ cucione illius ordinis».

245 SH IV, 25-26: «E porque a los saçerdotes perteneçe de lo saber e mostrar a los simples omes, mayormente a los clerigos curas... e algunnos, por ynorançia o por mengua de lo non poder aver, non saben los articulos de la fe nin... por ende... todos los clerigos curados de nuestro obispado tomen e tengan en sus yglesias escritos los articulos de la fe... lo cual les mandaremos dar escrito apartadamente en un quaderno, e mandamos que lo fagan escrivir en pargamino cada uno, a costa de la fabrica de las yglesias. E que este para sienpre en ellas, e que sean tenidos de lo dezir e predicar a sus pueblos...».

${ }^{246}$ SH IV, 29: «Non deven ser reçebidos los clerigos pelegrinos e de otro obispado... los quales non se pueden nin deven observar fuera de sus obispados, nin aun para venir al Estudio, syn aver prymeramente liçençia espeçial de sus perlados para ello». 
En la constitución sexta, que trata de las visitas del arcediano y del arcipreste al territorio de su respectiva jurisdicción, entre las actuaciones que debe llevar a cabo el arcediano en la visita, figura en primer lugar la de cerciorarse sobre cómo cumplen los clérigos curados su oficio; si no lo cumplieren satisfactoriamente, deberán mostrarles los fallos y amonestarles a que lo aprendan bien, poniéndoles alguna pena a este efecto ${ }^{247}$.

Se observa que el desconocimiento del oficio es la causa primera y principal, por encima de malicias o descuidos, de los fallos en el cumplimiento del mismo.

El cuaderno prometido no se elaboró hasta más tarde, durante el episcopado de Gonzalo de Alba (1408-1412), quien lo impone en el sínodo de $1410^{248}$.

En el proemio del libro sinodal, el obispo hace una reflexión sobre la importancia de que los clérigos curados sepan las cosas que tocan a la fe y al régimen de las almas; precisamente para que tengan estos conocimientos y no presenten excusas de ignorancia, se ha elaborado dicho libro ${ }^{249}$. En este sentido se expresa, también, en la constitución primera del sínodo ${ }^{250}$.

Sobre los saberes mínimos: lectura, canto y gramática, no hace mayor hincapié; en lo que insiste es en el conocimiento de las cosas que pertenecen al oficio curado en su vertiente ad homines; y no se trata de un saber personalizado y profundo, sino de un conocimiento puramente instrumental. Importa que tengan a mano lo que deben enseñar y que lo digan, o lean, al pueblo según su mayor o menor saber y entender. Por eso, para los ignorantes, se elabora un cuaderno, el libro sinodal, que deberán tener y estudiar para, así, poder cumplir bien, correctamente, el oficio pastoral de la cura de almas.

247 SH IV, 31-32:» Prymeramente,en que manera dan e administran los sacramentos de santa Yglesia... E sy fallaren en ellos lo sobredicho, den graçias a Dios, e sy non, demuestrenles lo que desfalleçe e amonestenles que bivan bien e castamente, e deprendan e sepan todo el ofiçio que a ellos perteneçe a saber, poniendoles alguna pena que fasta çierto dia cunplan lo que les mandaren en este caso".

248 Sobre esta obra, su versión al castellano, su originalidad y su difusión, cf. A. GARcí y GARCí, F. CANTElar Rodríguez y B. AlONSO RodRIGUez, El <Liber synodalis > salmantino de 1410, «Revista Española de Derecho Canónico», 41 (1985), pp. 347-364. Este artículo aparece publicado asimismo en la obra de A. GARCIA Y GARCIA, Iglesia, Sociedad y Derecho, 2, Salamanca, 1987, pp. 433-450.

249 SH IV, 72: «Idcirco nos, frater Gundisaluus... cupientesque quod in hiis que ministros huiusmodi scire decet et exequi circa administrationem sacramentorum Ecclesie, ex simplicitate eorum uel ignorantia error non sequatur aliquis uel defectus, cum nostro concilio deliberatione habita diligenti, et assensu capituli nostri Salamantini, quedam super hiis utilia et necessaria in hoc Libro synodali sub compendio posuimus».

${ }^{250} \mathrm{SH}$ IV, 51-52. 
El capítulo décimo del libro sinodal distingue tres grados de exigencia en el conocimiento del contenido de la fe, grados que corresponden a la triple categoría de personas miembros de la Iglesia: categoría suprema, formada por el papa y los obispos; categoría media, a la que pertenecen los clérigos curados y los docentes de oficio, como los predicadores y doctores; categoría baja, compuesta por el pueblo, los legos.

Con relación a los de categoría media, éstos deben conocer lo que pertenece a su oficio, es decir, los artículos de la fe en cuanto a la substancia, y lo que respecta a la administración de los sacramentos, como saber distinguir entre pecado mortal y venial y qué penitencia se debe imponer por uno u otro pecado; en general, todo cuanto corresponde a la salvación de las personas a ellos encomendadas ${ }^{251}$.

En definitiva, preocupa ante todo la relación del clérigo cura con los fieles; por encima, en cierto sentido, de la relación del clérigo cura con Dios.

En este orden de cosas, además de lo indicado en el capítulo décimo, más adelante, en el capítulo número 23, expone lo que debe saber el sacerdote confesor (lo era el curado por excelencia), y detalla cuatro cosas: 1) saber a qué pecados alcanza su potestad, es decir, los casos reservados; 2 ) discernir los pecados mortales de los veniales; 3 ) conocer los cánones penitenciales para aplicar bien la penitencia ${ }^{252}$; 4) la forma -fórmula- de la absolución ${ }^{253}$.

El capítulo número 64 del mismo libro sinodal se hace eco de las disposiciones canónicas sobre los tiempos de las órdenes y las cualidades de los ordenandos, y pone como primera cualidad la de ser persona letrada; precisamente para garantizar ésta y los demás requisitos, las órdenes (se refiere aquí a todas, a las sagradas o mayores y a las no sagradas o menores) no se han de conferir sin previo examen del candidato ${ }^{254}$.

251 SH IV, 80: «Vnde triplex est gradus in Ecclesia: quidam sunt supremi, ut papa et episcopi; quidam medii, ut sacerdotes et curati simplices; quidam infimi, ut populares... Medii uero in Ecclesia sunt curati simplices et qui ex officio habent alios docere, ut predicatores et doctores. Et isti tenentur explicite scire quidquid pertinet ad officium suum, scilicet ad articulos quantum ad substantiam eorum, et quidquid pertinet ad administrationem sacramentorum, et discernere quid est peccatum mortale et quid ueniale, et qualis penitentia iniungenda est pro mortali et qualis pro ueniali, et sic de aliis que pertinent ad salutem animarum sibi commissarum».

252 Esto no quiere decir que la penitencia tarifada mantuviera todavía su vigor como tal; simplemente, constituía una ayuda a la hora de adecuar la pena al pecado.

${ }^{253}$ SH IV, 97-98: «Sciendum autem quod sacerdotes uolentes audire confessiones, saltim quatuor de necessitate debent scire. Primo, ut sciat sacerdos ad que peccata se extendit potestas sua, et potest scire maxime per notitiam casuum episcopalium... Secundo, debet scire que sunt peccata mortalia et que uenialia. Tertio, debet scire canones penitentiales. Quarto, debet scire sacerdos formam absolutionis».

${ }^{254}$ SH IV, 154: «Conferri autem debent dicti ordines homini litterato... Conferendi uero sunt predicti ordines examinatione precedente». 
Cuarenta años después, el obispo Gonzalo de Vivero (1447-1480), en el sínodo celebrado el año 1451 , constitución segunda, reconoce que el cumplimiento de la normativa diocesana anterior al respecto no era satisfactoria e insta a su observancia, reforzando la norma con nuevas penas. Además, eleva de categoría el libro sinodal de Gonzalo de Alba; de libro de uso o vademecum pasa a libro de texto para los clérigos; éstos deberán estudiarlo con diligencia para instruirse y, así, informar mejor a los fieles ${ }^{255}$.

El obispo Diego de Deza (1494-1498), en el sínodo que celebró el año 1497 no trata abiertamente de la ciencia clerical, pero el tema sale a relucir en la constitución número 29 , en la que se regula la visita de los arcedianos y arciprestes a las iglesias de su ámbito jurisdiccional. La primera actuación del arcediano versará sobre si los curados saben cumplir, y cumplen, correctamente su oficio; y si hallare defectos de ciencia, además de reprender y castigar a los ignorantes, se ocupará de que en un tiempo prudencial (no se señala un tiempo determinado) subsanen su deficiencia ${ }^{256}$.

Diego de Deza toma esta normativa sobre la forma de visitar, según él mismo precisa, de sus predecesores, reduciendo y trayendo a conformidad la variedad de la normativa anterior.

En cuanto al tema del saber clerical, Diego de Deza se inspira, a veces de manera literal, en el sínodo de 1396, celebrado por su antecesor Diego de Anaya y Maldonado. En la redacción de Diego de Deza queda aún más claro que en la de su homónimo Diego de Anaya que es la ignorancia la causa principal del incumplimiento, o del mal cumplimiento, del oficio ${ }^{257}$.

\section{5) Badajoz}

A mediados del siglo XIII, posiblemente el año 1255, celebró sínodo Pedro Pérez, primer obispo de la recién restaurada diócesis pacense. En este sínodo no hay referencia alguna a la ciencia del rector de almas, pero la

${ }^{255}$ SH IV, 307: «Mandamos, otrosy, que el Libro synodal que fizo el obispo don frey Gonçalo, de devota memoria, nuestro predeçesor, que lo tenga en sy cada uno de los dichos clerigos e curas perrochiales, e estudien en el con deligençia, por que ellos sean mejor ensennados e inistrutos, e puedan en ello mejor enformar a los clerigos (sic, por error; léase: legos\}».

${ }^{236}$ SH IV, 384-385: «Vista la variedad de diversas constituciones, fechas justa e sanctamente por nuestros antecessores... queriendolas redizir e traer a conformidad... mandamos... la forma siguiente... primeramente, en que manera dan e administran los sacramentos... preguntando de cada uno de los sacramentos particularmente todo lo que deve saber el clerigo o ministro que los ha de administrar... E si fallare algunos defectos en la sciencia, o en lo que devieren saber, reprehendalos e mande que dentro de cierto tiempo sepan todo el officio que a ellos pertenesce saber, poniendoles alguna pena».

${ }^{257}$ Compárese el texto de la nota anterior con el transcrito en la nota 247. 
constitución sexta trata de las cualidades del sacristán, lo cual constituye un punto de referencia válido para hacernos una idea de lo que se pensaba que debía saber el clérigo curado.

Según dice dicha constitución, no se debía encomendar el oficio de sacristán a un lego, ni a un clérigo casado o mozuelo, ni a un clérigo de misa; para sacristán se debía escoger a un clérigo con capacidad y honestidad para servir humildemente «a la clereçia e al pueblo»" 258 .

Un estudio comparativo de textos sinodales relativos a la figura del sacristán nos lleva a la conclusión de que al sacristán se le exige, en cuanto a ciencia, ser suficientemente letrado, en grado tal como para atender al sacerdote en la misa y en la recitación de las horas (pronunciar y leer latín, aunque no lo entienda) y atender al pueblo en la enseñanza de la doctrina a los niños; el sacristán venía a ser monaguillo y, a la vez, maestro de escuela primaria. Así, en principio, resulta evidente que el cura no debía ser menos docto que su sacristán.

Ya no tenemos nueva documentación sinodal de la diócesis pacense hasta el mismo umbral del siglo XVI, por lo que ignoramos si en los sínodos celebrados en estos dos siglos y medio se trató y reguló el tema. El obispo Alonso Manrique de Lara (1500-1516) celebró sínodo el año 1501; en este sínodo se trata ampliamente del tema de la ciencia clerical en los títulos quinto y sexto, sobre todo en este último, cuyo enunciado es bastante expresivo al respecto: «De la instrucion de los clerigos y de las cosas que deven saber».

En el título quinto, constitución primera, se dispone que el examen que se ha de hacer a los clérigos antes de darles órdenes o reverendas (también llamadas dimisorias, o sea, letras para poder recibir órdenes de un obispo distinto al propio) versará sobre tres aspectos: vida, costumbres y ciencia, como mandan los cánones. La responsabilidad del examen mismo descansa en el provisor u oficial ad boc del obispo. Con relación a los conocimientos a exigir, se concretan en que sepan bien leer, construir y cantar; en cuanto a cantar, que tengan al menos principios del canto, que viene a ser lo habitual, lo tradicional, para las órdenes sagradas en general. El examen se ha de pasar cada vez que uno es promovido a una orden superior, de subdiácono a diácono y de diácono a sacerdote ${ }^{259}$.

258 SH V, 13: «Otrosi, ordenamos que non sea sancristan ningun lego, nin clerigo casado nin moçuello, nin clerigo de missa, mas otro clerigo, e sea tal que pueda e sepa bien homildosamiente servir a la clereçia e al pueblo, e de sofiçientes prendas o fiadores por que todas las cosas de la yglesia sean salvas».

259 Esta disposición se recoge asimismo en el sínodo placentino de 1534 , siendo obispo Gutierre Vargas de Carvajal (ca. 1500-1559), en la c.43 (SH V, 437-438): «Que, asimesmo, no se den reverendas a persona alguna para mas de un orden sacro, por que, visto como usa y bive en la orden de subdiacono, parezca si meresçe ser promovido a otra mayor orden, salvo si 
Esta disposición afecta solamente a las órdenes sagradas o mayores, no a las menores. De otra parte, los candidatos al sacerdocio serán examinados, además, sobre los sacramentos y el significado de las palabras y ceremonias de la misa; o sea, un examen que exige del examinando conocimientos de teología, cánones y liturgia ${ }^{260}$.

El título sexto se dedica todo él, en sus cuatro constituciones, a los saberes propios de los clérigos con cura de almas. La primera constitución contiene el conjunto de conocimientos básicos, de fondo, que debe poseer todo sacerdote y, especialmente, los que sirven en parroquias, es decir, curados. Las otras tres responden a saberes concretos que el sínodo cree oportuno poner aparte o de relieve, sin duda a causa de su mayor repercusión en la comunidad local. Es clara, en todo caso, la orientación preferentemente ad bomines del conocer y del quehacer del sacerdote ${ }^{261}$.

Conforme a la constitución primera, los curados deben saber de coro, de memoria, el contenido de la doctrina cristiana y las cosas más necesarias a su oficio: palabras de la absolución, palabras del bautismo, significado de las palabras y ceremonias de la misa, etc. A los ignorantes les da cuatro meses para despejar su ignorancia, pasados los cuales, si se hallara que no saben, se les quitarán los frutos de sus beneficios y, si no fueren beneficiados, se les apartará del servicio que presten; así hasta que aprendan lo que deben saber. Como medida complementaria, el provisor, o visitador en su caso, no concederá licencia de misa sin cerciorarse de los conocimientos de quien la solicita, de modo que si el solicitante no presenta prueba de haber superado el examen, le examinará él mismo o mandará examinarle en su presencia, si tal provisor o visitador no fuere sacerdote ${ }^{262}$.

a nuestro visitador o examinador les paresçiere que el tal ordenante es ydoneo e sufiçiente e ynstruto para se ordenar de todas ordenes».

La excepción aquí considerada por el obispo Vargas de Carvajal no se incluye en el sínodo pacense.

$260 \mathrm{SH} \mathrm{V}, 56-57$ : «Establecido es por los sacros canones que ningun clerigo sea promovido a orden sacro, sin que primeramente sea examinado de su vida e costumbres e de la sciencia que ha de saber... E si no fuere fallado alguno de los dichos pecados... e supiere bien leer e construir e cantar o tuviere principios del canto, que sea admitido a las ordenes o se le den reverendas para que las pueda recebir. Pero es nuestra intencion, y asi lo mandamos, que a ningun clerigo sean dadas reverendas para recebir mas de de uno de los ordenes sacros, por que, despues de visto como bive y usa en la orden de subdiacono e parezca que meresce ser promovido a mayor orden, le sea dada... e en tal que los que han de ser promovidos a sacerdocio sean examinados cerca de los sacramentos e que significan las palabras e cerimonias de la missa, e den del todo entera razon, como convienex.

${ }^{261}$ Las disposiciones del título primero: «De los articulos de la fe e de las cosas que los clerigos han de enseñar y amonestar a sus parrochianos» ( $\mathrm{SH} \mathrm{V,} \mathrm{20-35),} \mathrm{con} \mathrm{sus} \mathrm{once} \mathrm{consti-}$ tuciones, son una prueba más de esta orientación preferente ad bomines.

262 SH V, 58-59: "Al officio de los sacerdotes pertenesce estudiar y procurar de saber 
La constitución segunda se refiere a los casos reservados. El obispo delega en los curados la facultad de absolver de todos los casos reservados, excepto de diez, siendo el primero de éstos el «acceso carnal a mora o a judian ${ }^{263}$.

Las constituciones tercera y cuarta atienden a una situación no ordinaria que, circunstancialmente, podía afectar, y gravemente, a una iglesia o territorio determinado: la situación de entredicho. Los curados deben saber qué sacramentos se pueden administrar y qué fiestas se pueden celebrar, según las circunstancias, mientras dure el entredicho.

Es frecuente que, por una u otra razón, la pena de entredicho venga a colación en los sínodos, pero no es frecuente que aparezca como aquí aparece, o sea, inserta, y de forma destacada, entre los saberes propios de los curados $^{264}$.

\section{6) Coria}

Conocemos las constituciones del sínodo de 1406, celebrado por el obispo García de Castronuño, por estar incluidas en bloque en el sínodo de 1462, celebrado por el obispo Iñigo Manrique de Lara (1457-1475). Constituyen un bloque de treinta y una constituciones. En la copia editada por el Synodicon Hispanum la numeración de las sinodales es continuada, de modo que las del obispo García de Castronuño llevan los números 1-31 ${ }^{265}$.

Por lo que hace a nuestro tema, interesa la constitución octava. No trata del saber clerical directamente, sino de la obligación de predicar-enseñar la doctrina a los fieles; con este motivo, precisa que pone lo básico de la doctrina justamente "por la inorancia de los simples, asi clerigos como legos, que non se puedan escusar con razon de non saber» ${ }^{266}$.

las cosas que son obligados, asi para su instrucion como para doctrina del pueblo... todos los sacerdotes, especialmente aquellos que sirven las yglesias parrochiales de nuestro obispado, sepan de coro los articulos de la fe en romance y en latin... las palabras de la absolucion... las palabras esenciales del baptismo... E si pasados quatro meses... algund clerigo fuere fallado que no sabe... si fuere beneficiado, que no goze de los frutos de su beneficio hasta que lo sepa... y si no fuere beneficiado... que le quiten el servicio del beneficio o capellania hasta que sepa lo suso dicho. Otrosi, mandamos a nuestro provisor o visitador que quando a alguno se uviese de dar licencia para dezir missa, le examine... si antes no uviere sido examinado... y si nuestro provisor o visitador no fuere sacerdote, que lo mande examinar a algun sacerdote en su presenciax.

${ }^{263}$ SH V, 59-60: "Que sepan los casos que nos tenemos en costumbre de reservar».

${ }^{264}$ c.3 (SH V, 60): «Que deven saber quales son los sacramentos que se pueden administrar en tiempo de entredicho»; c.4 (SH V, 61): «De las fiestas que se pueden celebrar solemnemente en tiempo de entredicho".

${ }^{265}$ Cf. SH V, 115-118.

$266 \mathrm{SH} \mathrm{V}, 129$. 
Una vez más, nos encontramos con la tabla de la doctrina como ayudante del curado y, a la vez, como sustitutoria, en la práctica, del aprendizaje mínimo exigible. Cierto es que, en la mayoría de las ocasiones, los curados ignorantes aludidos en éste y en otros sínodos de esta forma simple, sin conminarles la obligación del estudio y del aprendizaje, no debían ser ya hábiles para aprender, por razón de la edad (treinta-cuarenta años), por lo que estaban dispensados del estudio; la tabla constituía realmente para ellos una ayuda importante, junto a otros libros, llamados sacramentales y confesionales; libros que «los buenos curas» debían tener ${ }^{267}$.

Tampoco el corpus sinodal propio de Iñigo Manrique de Lara del sínodo de 1462, constituciones números 32-59, trata ex professo de la ciencia clerical; pero interesan varias sinodales, en las que se indica la titulación académica exigible para poder ser promovido a determinadas dignidades y beneficios.

Así, para ser deán se exige el título de doctor, licenciado o, al menos, bachiller, en teología o en cánones ${ }^{268}$. Para ser chantre se exige ser letrado (leido, instruido) en cánones o en teología, o bien maestro o graduado en una de ellas, además de saber los oficios divinos y conocer bien el arte del canto llano; dada la importancia del canto en este oficio, el candidato a chantre deberá sufrir un examen sobre el arte del canto ante un tribunal compuesto por un mínimo de dos personas, una o más a designar por el obispo (si no es él mismo) y otra por el cabildo ${ }^{269}$. Para optar a canónigo racionero se exige ser, al menos, buen gramático ${ }^{270}$.

La sinodal número 47 se refiere a un caso especial, pero que es significativo de la progresión en la exigencia de ciencia a los clérigos en conformidad con los papeles que representan, es decir, en conformidad con la dotación económica, o renta, del beneficio, y con la importancia que se da a las responsabilidades que se les encomiendan.

267 Ibid.

268 c.34 (SH V, 143): «Pero ordenamos que ninguno non pueda ser elegido al dicho deanazgo nin haberlo, sin ser graduado doctor o licenciado, o a lo menos bachiller formado, en teologia o en canones».

269 c.35 (SH V, 143): «Que sea letrado en ciencia de derecho canonico o de teologia o maestro o graduado en una destas facultades, e buen eclesiastico en saber los oficios divinales de las Horas canonicas, e que sepa bien el arte del canto llano, en la qual ciencia desta musica e canto llano queremos que sea examinado... E queremos que la dicha examinacion sea fecha por nos o por la persona o personas que nos deputaremos, con otra persona que sea deputada por parte de nuestro cabildo».

270 c.37 (SH V, 144): «Por ende, ordenamos que los sobredichos dean e cabildo non puedan elegir, nin los dichos racioneros haber las dichas raciones, salvo si fueren clerigos de misa, o de orden sacro, con tanto que sean en edat que entre en veinte e cinco años para poder haber el dicho orden presbiteral, e buen gramatico a lo menos". 
Se trata, en concreto, de los requisitos que debe reunir el clérigo curado del altar de San Miguel, altar que estaba situado a la izquierda de la capilla mayor de la iglesia catedral ${ }^{271}$. Dicho clérigo tenía a su cargo la cura de almas, incluido el fuero penitencial, de las dignidades y beneficiados de la catedral, en calidad de cura perpetuo y particular de los mismos; debía oirles en confesión y administrarles los sacramentos. Para ser elegido cura de San Miguel se exige, ad validitatem y como exigencia mínima, poseer el grado de bachiller en cánones, en teología o en artes.

Esta constitución es innovadora y el propio obispo así lo atestigua; lo es en dos aspectos: en cuanto a la exigencia de graduación, y en cuanto a la anexión a dicho beneficio de la cura in foro poenitentiali de las dignidades y beneficiados, tarea que hasta entonces correspondía al propio obispo ${ }^{272}$.

\section{7) Oviedo}

El obispo Gutierre de Toledo (1377-1389) manifiesta en sus sínodos una gran preocupación por el cumplimiento satisfactorio de las obligaciones pastorales de sus curados. Su interés por los estudios clericales queda asimismo de manifiesto, y de una manera relevante, en la fundación de un colegio para estudiantes pobres de derecho canónico en Salamanca ${ }^{273}$.

Gutierre de Toledo no aborda directamente, en los sínodos, la cuestión relativa al conjunto de conocimientos que los clérigos deben poseer, pero, al tratar de la obligación de los curados de enseñar la doctrina y administrar los sacramentos al pueblo, da un buen testimonio de lo que deben saber, y muchos no saben.

En su primer sínodo, año 1377, señala como obligación principal de los curados la de enseñar a los fieles las cosas por las que han de salvarse; y para facilitar y asegurar en la medida de lo posible esta enseñanza, les

271 Estos datos se hallan en la sinodal anterior, número 46 (SH V, 149).

272 c.47 (SH V, 149): «Pero por quanto la renta del dicho beneficio es gruesa e asimismo ha de tener cura de las animas de los dignidades e beneficiados de la dicha nuestra yglesia... innovamos que non pueda haber el dicho beneficio nin pueda ser elegido ningun clerigo a el, menos que sea bachiller graduado en derecho canonico o en teologia o en artes. En otra manera, la dicha eleccion, como dicho es, sea en si ninguna. E al dicho cura... desde agora le cometemos la cura in foro penitentiali de los dichos dean e cabildo e beneficiados e capellanes, la cual fasta agora se decia pertenescer a nos particularmente e non al dicho cura de san Miguel, e lo instituimos por cura perpetuo e particular de los dichos beneficiados... para que los oya de penitencia e administre los sacramentos».

273 Cf. F. Javier Fern ÁnDez CONDE, Gutierre de Toledo, obispo de Oviedo (1377-1389). Reforma eclesiástica en la Asturias bajomedieval, Oviedo, 1978, pp. 143-149, 168-170 y 253258. 
impone un cuaderno, escrito en romance, con las enseñanzas fundamentales de la doctrina cristiana, por el que los curados informarán a sus fieles ${ }^{274}$.

En el sínodo de 1382, en la constitución segunda, que coincide casi ad litteram con la constitución segunda de las dadas un año antes para el arcedianato de Babia, afirma el obispo que en la visita realizada a la diócesis pudo comprobar que el cuaderno de la doctrina era desconocido por sus curados; los cuales, por otra parte, no sabían la doctrina de memoria ni, consecuentemente, la enseñaban a los fieles. Les da un plazo de unos dos meses para que la aprendan de memoria: del 1 de diciembre de 1382, fecha del sínodo, "fasta el dia de Entroydo que primero viene», es decir hasta el principio de la Cuaresma o Carnaval. A los transgresores les impone una pena pecuniaria de veinte maravedíes, que se aplican íntegramente a la obra de la catedral ${ }^{275}$.

El obispo ovetense reconoce dos cosas. En primer lugar, que el cuaderno de la doctrina no había sido adquirido por sus curados o, al menos, si lo habían comprado, lo tenían abandonado en algún rincón, sin estudiarlo ni darle uso; en segundo lugar, que dicho cuaderno era del todo necesario, puesto que sus curados, en líneas generales (no hace precisiones de si muchos, todos o sólo algunos), eran unos perfectos ignorantes de la doctrina.

También halló en la visita que muchos curados no sabían de memoria el canon de la misa, pese a lo cual se atrevían a celebrar sin misal; lo prohibe bajo multa de treinta maravedíes, asimismo para la obra de la catedral ${ }^{276}$.

A mediados del siglo XV, la simpleza de algunos clérigos curados de la

${ }^{274}$ c. 1 (SH III ${ }_{i}$ 396): «Porque, segun las ordenaçiones de los santos padres, la principal carga et cura que deven aver los que han algunos subditos es a ensennarles aquellas cosas por que han de seer salvos... ordenamos que todos... resçiban et llieven et ayan un quaderno en romançe de los diez mandamientos... Et trayan a cada uno de los signados el dicho quaderno de los mandamientos et lo presenten a nos o aquellos que por nos fueren dados para los resçebir, so la dicha pena de los veynte $\mathrm{mr}$.

${ }^{275}$ SH III, 439-440: *Verdaderamientre pueden seer reprehendidos los rectores que non saben las cosas que son nesçesarias a ellos et a los sus pueblos... Et por quanto fallamos por la dicha vesitaçion que feziemos, commo dicho es, que los cureros et rectores del dicho nuestro obispado non tenian la sobredicha enformaçion, que nos ordenamos en un quaderno en la primera signado que nos celebramos... nin los sabian de cuer, segun que devian, nin los denunciavan a sus pueblos... mandamos que todos los rectores que los sepan de cuer fasta el dia de Entroydo que primero viene, et enformen... Et los que lo non sopieren en el dicho termino et non enformaren a sus feligreses en ellos, commo dicho es, pechen veynte mr. para la obra de nuestra eglesiax.

Para el arcedianato de Babia, el plazo fijado no llega a los dos meses: del 20 de septiembre, data de las constituciones, al 11 de noviembre: «... por ende mandamos que todos los rectores que lo sepan de cuer fasta primero dia de Sant Martino primero que viene» (SH III, 430).

${ }^{276}$ c.9 (SH III, 445): «Commo la memoria de los omes sea flaca, et por experiençia manifiesta ayamos fallado, por la vesitaçion que avemos fecho en nuestro obispado, que muchos capellanes et clerigos de mysa nno saben el canon... et çelebran sin libro... ordena- 
diócesis ovetense daba lugar a que algunos pillos abusaran de las letras apostólicas. Cierta gente espabilada, dándose cuenta de que los curados a los que les presentaban dichas letras no las entendían, por no saber latín, aseguraban que contenían tales o cuales privilegios ${ }^{277}$.

\section{8) Burgos}

El obispo Juan de Villacreces (1394-1404) manifiesta en Burgos la misma preocupación pastoral que, poco antes, Gutierre de Toledo había evidenciado en Oviedo.

En el sínodo que celebró en fecha aún no fijada, pero en los albores del siglo XV, según Nicolás López Martínez ${ }^{278}$, establece que los curados tengan por escrito, en latín o en romance, según quieran, el cuaderno de la doctrina, por el que deben informar a los fieles. En cuanto al libro de las constituciones sinodales, se conforma con que lo tengan los arciprestes en su sede, se supone que a disposición de todos los curados de su jurisdicción.

El cuaderno lo deben aprender de memoria, en el plazo de un año («fasta el primero sínodo que se sigue», lo que equivale a un año, puesto que el sínodo se debía celebrar anualmente), no sólo los clérigos curados sino todos los clérigos de órdenes sagradas. La pena para los que no lo aprendan en el plazo dado es de treinta maravedíes para los curados, pero para los no curados es inferior y graduada según la orden de cada cual: de veinticinco para los sacerdotes no curados, de veinte para los diáconos, y de quince para los subdiáconos ${ }^{279}$.

mos que... non çelebre sinon por libro... Et quantas vegadas non lo feziere asi et le fuer sabido, pague treynta mr. para la obra de nuestra eglesia».

La sarra o canon de la misa no se debía decir nunca de memoria. Es un mandato que aparece en bastantes sinodales; en algunos casos, se alega desconfianza de que lo sepan bien; en otros, simplemente, se expresa miedo a errores y equivocaciones, que en el caso se consideran de especial gravedad.

277 Sínodo del obispo Iñigo Manrique de Lara (1444-1457), c.3 (SH III, 453): «Grandes querellas avemos resçebido de algunas personas del dicho nuestro obispado çerca de algunas letras apostolicas que son poblicadas de algunas indulgençias e perdones. E por la symplesa de algunos curas de non entender lo que se contiene en las dichas letras apostolicas, les son predicadas grandes abosiones e otras muchas cosas que non son contenidas en las dichas letras apostolicas».

La atribución de esta constitución, y las demás del lote, al sínodo de 1450, es probable, pero no segura, según precisan los editores del Synodicon en la breve introducción al sínodo (p.452).

278 Sinados burgaleses del siglo XV, «Burgensew, 7 (1966), p. 211.

279 López Martínez 221: «Porque los arciprestes e vicarios e los otros curas de la yglesia, por el oficio que tienen, son tenidos de enformar... Por ende... ordenamos por estas presentes constituciones que... reciban e lieuen en latin o en romance, qual más quisieren, los artículos de la fee e los mandamientos... Otrosí que lieuen los arciprestes las constituciones e 
En esta misma línea pastoralista se sitúa Juan Cabeza de Vaca (14071413) en el sínodo celebrado el año 1411.

En el título De celebratione missarum se detalla el oficio triple del curado: culto, enseñanza-predicación y administración sacramental ${ }^{280}$.

En el título De Summa Trinitate se denuncia que «algunos de los beneficiados», con referencia muy especial a los curados, no saben la doctrina ni se cuidan de saberla; y, por ello, no aciertan a cumplir bien con sus obligaciones, como son confesar e instruir, sobre todo a los conversos y a los ignorantes. Da un plazo de seis meses para aprenderla, al cabo del cual serán examinados por el propio obispo o por un delegado suyo ${ }^{281}$.

El título Del oficio de los arciprestes coincide en su contenido casi verbo ad verbum con el correspondiente del obispo Juan de Villacreces antes citado, en el que se exige tener por escrito, en latín o en romance, el cuaderno de la doctrina, usarlo para informar al pueblo y aprenderlo de memoria en el plazo de un año, de sínodo a sínodo ${ }^{282}$.

Este plazo de un año se contradice con el de seis meses dado en el título De summa trinitate. La explicación de esta contradicción y de otras similares que, a veces, se advierten en los sínodos, puede estar en que muchas constituciones están tomadas íntegras (salvo, y tampoco siempre, la multa pecuniaria, que se suele poner al día) de cuerpos sinodales anteriores, y son aprobadas sin más.

Lo cierto es que Juan Cabeza de Vaca no conoce las sinodales de Juan

tengan en la cabeça del arciprestadgo... E otrosí mandamos que todos los sobredichos e los clérigos no curados de nuestro obispado e los diáconos e subdiáconos, que fasta el primero sínodo que se sigue sepan de auer estas cosas que en esta constitución se mandan saber e tomar e lleuar... que lo sepan muy bien todo de coraçón... E los que assí no quisieren decorar... que los arciprestes e vicarios e curas que pechen cada vno treynta mrs.: e los no curados cada veynte e cinco mrs: e los diáconos cada veynte mrs cada vno, e los subdiáconos quinze mrs cada vno*.

280 López Martínez 279: «Los curas otrosí digan missa, e encomienden las fiestas, e pedriquen las palabras de Dios, e denuncien e publiquen a sus pueblos las cosas que el Cardenal Legado e nos ordenamos en nuestras constituciones, e baptizen, e oyan de confessiones... ca esto pertenesce a su oficio».

281 López Martínez 241: «Primeramente, por quanto nos es dado entender que algunos de los beneficiados... no saben los artículos de la fee, e los siete sacramentos... por lo qual los tales negligentes no pueden ordenadamente confessar sus pecados, ni oyr de confessiones a otros, ni responder a los que les preguntan sobre lo susodicho, especialmente a los nueuamente conuertidos a la fee e a los simples e ignorantes... asignando a los susodichos, e cada vno dellos, para que sepan de coraçón todo lo susodicho: del día de la publicación destas nuestras presentes constituciones fasta seys meses primeros siguientes para las dar e dezir a nos e a otro qualquier a quien lo nos encomendaremos».

282 López Martínez 249-250. El sínodo «según las constituciones, así del Cardenal de Sabina legado que fue en España, como según las constituciones synodales de nuestro obispado, se hauía de fazer en cada año» (Ibid., p. 241). 
de Villacreces, según su propio testimonio. En el prólogo a las suyas, al indicar las razones que le impulsaron a celebrar el sínodo, afirma que «del tiempo que era obispo de Burgos don Domingo [Domingo Fernández de Arroyuelo, 1366-1380\} nuestro antecessor, que fue tercero obispo de Burgos ante de nos, no se auía fecho synodo en el dicho nuestro obispado" ${ }^{283}$.

Quiere decirse que uno y otro obispo tienen una fuente común a mano: o las constituciones sinodales de obispos anteriores de la diócesis o, quizás, una colección de sinodales que circulaba por Castilla o por toda la Península.

En cuanto al cuaderno de la doctrina que ambos insertan en sus respectivos sínodos, es igualmente claro que hacen uso de una fuente común, que no es otra que el llamado Catecismo castellano del siglo XIV ${ }^{284}$. El texto de Juan Cabeza de Vaca es algo más amplio y, en algunos puntos, está dispuesto con otro orden; pero es evidente que se trata del mismo «catecismo".

Con la misma finalidad pastoralista de facilitar a los curados el ejercicio correcto de su oficio ad bomines, en el sínodo de 1412, en el título De vita et bonestate clericorum, Juan Cabeza de Vaca ordena a los mayordomos de las iglesias que se encarguen de hacer «buenos manuales para dar los sacramentos del baptismo, e del velar, e del vnciar, e del enterrar... e que sean de buena letra por que los clérigos sepan bien leerlos» ${ }^{285}$.

Pablo de Santa María (1415-1435) no se ocupa directamente del tema de la ciencia clerical en sus sínodos. Sin embargo, viene a cuento destacar su meticulosidad respecto de las palabras con las que se expresan las verdades de la fe y, consiguientemente, su empeño en que haya propiedad en lo que se dice y enseña.

La única finalidad de las disposiciones del sínodo de 1418 es corregir el articulado de la fe de su antecesor Juan Cabeza de Vaca, por entender que contiene impropiedades, equivocaciones y lagunas de gran peligrosidad. Estas imprecisiones y errores afectan también, lógicamente, al articulado de la fe de Juan de Villacreces y al del «catecismo del siglo XIV» en casi los mismos puntos, aun cuando Pablo de Santa María sólo menciona a Juan Cabeza de Vaca ${ }^{286}$.

\footnotetext{
283 López Martínez 241.

284 Cf. J.M. SOTO RABANOS, ob. cit., pp. 604-605.

28s Lopez Martínez 296.

286 Título De summa trinitate (López Martínez 305-306): «E por quanto en las constituciones del obispo don Juan Cabeça de Vaca de buena memoria que fizo en el synodo... de mill e quatro cientos e onze... están puestos los artículos de la fee, romançados, no propiamente, e en algunos lugares desuiando della, e en otros lugares tirando lo que se deuía poner... considerando que, si esto fincasse por corregir, sería muy gran carga nuestra... Por ende, acordamos de notar las cosas en que los dichos artículos son de corregir... e después poner los artículos en la forma en que se deuen poner, en el romançe más seguro... e donde no falláremos tal romançe, poniendo el latín que es común usado de los doctores de la santa yglesia».
} 
En esta misma línea de inquisidor escrupuloso de la expresión apropiada de las verdades teológicas, Pablo de Santa María, en el sínodo de 1427, título De las predicaciones, llama al orden a algunos que, por malicia, ignorancia o indiscreción, predican (en el sentido propio de sermón, no ya de enseñanza de la doctrina) lo que no debieran, «cosas escandalosas e retractantes de deuoción e defendidas por los sanctos cánones « ${ }^{287}$.

Alonso de Cartagena (1435-1456), en el sínodo de 1443, título De summa trinitate et fide catholica, se preocupa, al igual que sus antecesores, de la divulgación, dígase enseñanza o predicación, de la doctrina cristiana. En este contexto recuerda que los curados deben saber de memoria la doctrina que han de enseñar; pero, si no la saben de memoria, se conforma con que la lean al pueblo por el cuaderno que debe haber en cada iglesia parroquial ${ }^{288}$.

Además, Alonso de Cartagena exhorta a los curados a que, tras la recitación o lectura de la doctrina, de la parte correspondiente al domingo en cuestión, glosen al pueblo la palabra de Dios, según sus posibilidades y con la máxima cautela, ya que respecto de la fe «no se podría ni deue añadir, ni menguar, ca della es escripto: no añadas ni mengües en sus palabras» (Deut. 4, 2; 12, 32). Y si hubiere algún religioso o clérigo para predicar ese día, él mismo dirá o leerá la parte de la doctrina que corresponda, antes del sermón propiamente dicho.

Será responsabilidad de los curados el notificar esta normativa al fraile o clérigo secular foráneo que hubiere de predicar en alguno de los domingos señalados: los cuatro de Cuaresma y el de Pasión ${ }^{289}$.

El sucesor de Alonso de Cartagena, Luis de Acuña (1456-1495), en el sínodo de 1474, título De summa trinitate, remite al compendio doctrinal de sus antecesores Juan Cabeza de Vaca y Pablo de Santa María, y recuerda lo establecido por Alonso de Cartagena sobre el calendario de publicación y glosa de la doctrina al pueblo en la Cuaresma.

Luis de Acuña se lamenta de que no se haya llevado a efecto lo mandado, sin temor a las penas establecidas, dado que la ejecución de estas penas se dejaba en manos de compañeros clérigos, los cuales se las perdonaban unos a otros. Pero no cambia este punto; simplemente, añade a las penas de sus antecesores la de un exceso contra el cura que no cumpla y contra los compañeros clérigos que no ejecutaren la condena primera.

287 López Martínez 308-309.

288 López Martínez 319: «Por ende... los curas... digan de coro si lo sopieren, según que saber deuen,e, si no lo sopieren, lean por vn quaderno los artículos de la fee... E para esto mandamos que desta nuestra constitución e de las dichas rúbricas fartículos de la fe, sacramentos, etc.), con lo so en ellas contenido, se faga vn quaderno e le tengan en cada yglesia parrochial, por donde lo lea el cura o aquél que las fiestas ouiere de dezir».

289 López Martínez 318-320. 
Por otra parte, Luis de Acuña se muestra también muy cauteloso respecto a la declaración de la doctrina y se excusa de entrar en profundidades: « ... a nos no es necessario dello más tractar, pues, como es escripto, de tales cosas conuiene mesuradamente hablar ${ }^{290}$.

Pascual de Ampudia (1496-1512), en el sínodo de 1498, título De prebendis, trata de ciertos abusos que se cometían para conseguir beneficios eclesiásticos. En la parte dispositiva, señala como criterio general preferente a seguir en la colación de beneficios, no ya el de estar ordenado, sino el de mayor suficiencia, sin que haga al caso *que no tenga otra orden sino corona".

El término «suficiencia» no hace aquí referencia exclusiva a la posesión de conocimientos; se refiere al conjunto de requisitos: edad, honestidad y ciencia.

De todas formas, la norma manifiesta una atención particular a la suficiencia de conocimientos, ya que, como criterio especial, y a igualdad de otras condiciones, si entre los aspirantes legítimos hay algún graduado en teología o en cánones, correspondiendo la ciencia al grado, éste será preferido a los demás.

Por la forma de dicción se da a entender que tal situación se daba con cierta frecuencia, como para tenerla en cuenta, y que el solo título no era garantía suficiente, por lo que se deduce que había algún examen o demostración de la competencia científica del interesado, si ésta no era notoria ${ }^{291}$.

Unos años más tarde, en el sínodo de 1503, Pascual de Ampudia modifica parcialmente la normativa anterior.

En esos años se ha percatado de que la preferencia en ciertos casos de los graduados en teología o en cánones para los beneficios patrimoniales no cumple, de hecho, el objetivo perseguido, es decir, que en las iglesias haya clérigos letrados que las sirvan, gobiernen y les den esplendor, puesto que dichos graduados, una vez provistos de sus respectivos beneficios, se ausentan y se van a los estudios o a otras partes, quedando las iglesias defraudadas.

Para salvar este escollo, refuerza la norma que obliga a residir en los

290 López Martínez 332.

291 López Martínez 360: «Otrosí, porque auemos visto muchas vezes sobre entrar en los beneficios hauer quistiones y diferencias, diziendo que los ordenados han de ser preferidos a los no ordenados; de lo qual se ha seguido buscar de se ordenar subreticiamente... por ende, para oviar los tales inconuenientes, ordenamos e establescemos que en las yglesias numeradas e en las no numeradas entren por su suficiencia siempre el más suficiente, no embargante que no tenga otra orden sino corona, de manera que no haya prelación alguna por respecto de las ordenes. Pero queremos, e es nuestra intención, que así en las yglesias numeradas como no numeradas, cada e quando que entre los fijos patrimoniales houiere algún graduado en theología o en cánones, correspondiendo la sciencia al grado, prefiera a todos los otros». 
beneficos patrimoniales; en adelante, el que se ausentare por tres meses continuos quedará privado de su beneficio ${ }^{292}$.

De otra parte, Pascual de Ampudia ha observado que tomar en todo caso como prioritario el criterio de la suficiencia, sin dar apenas relevancia al hecho de estar o no ordenado, corre en detrimento de muchos clérigos mayores, con cuarenta o más años, ya ordenados y que, siendo suficientes, no pueden alcanzar dichos beneficios, ni es de esperar que lo puedan conseguir en adelante, porque hay otros clérigos jóvenes graduados, recién venidos de los estudios, que tienen mayor suficiencia y se les adelantan.

Para solucionar este problema, modifica la disposición anterior de forma sustantiva: a la hora de cubrir las vacantes de beneficios patrimoniales, serán preferidos, entre los hijos patrimoniales de la iglesia respectiva, los de cuarenta o más años, siendo, claro está, suficientes; y, de entre ellos, si hay más de uno, el más suficiente, aunque hubiere otros de menor edad y con más estudios ${ }^{293}$.

Por lo que se ve, en la diócesis burgalesa no parece que hubiera problemas de suficiencia de ciencia clerical en tiempos de Pascual de Ampudia, al menos en cuanto a los requisitos mínimos deseables.

Un dato más puede avalar esta hipótesis. En el sínodo celebrado en Medina de Pomar el año 1500, Pascual de Ampudia denuncia que algunos

292 Título De clericis non residentibus (López Martínez 385): «Por vna nuestra constitución houimos ordenado e mandado que los graduados en theología o cánones se hayan de preferir en ciertos casos... a los no graduados, por que en las yglesias houiesse letrados que las decorassen e mejor gouernassen e seruiessen. E hauemos fallado que en (sic, por: el) fin para que fizimos la dicha constitución no se consigue,porque muchos de los tales graduados, después que son proveydos de los tales beneficios, no residen en ellos... se absentan e se van a los estudios o a otras partes donde les plaze... Por ende... sean obligados a residir e residan... con aperçebimiento que, si por tres meses continuos estuuieren absentes de los dichos sus beneficios, desde agora e por entonces los priuamos e hauemos por priuados de los tales sus beneficios".

293 Título De prebendis (López Martínez 385-386): «Por otra nuestra constitución... que... no houiesse prerrogatiua alguna por respecto de ser primero ordenado, saluo que todos entren por sufficiencia, excepto si alguno fuesse graduado en theología o cánones... e porque ay muchos clérigos en este nuestro obispado, de edad de quarenta años o más, que se han ordenado de missa de muchos tiempos, los quales a causa de la dicha nuestra constitución, avnque son sufficientes, no pueden hauer los dichos beneficios ni se espera que los haurán en toda su vida, porque acaesce hauer otros mancebos graduados que nueuamente vienen de los estudios... Por tanto... de aquí adelante, cada e quando acaesciere ... concurrir a la oposición algún clérigo presbytero... que sea de hedad de quarenta años o más, e seyendo suficiente, e sea preferido e prefiera a todos los otros menores de quarenta años, avnque sean graduados o más suficientes. E si... incurrieren dos o más clérigos fijos patrimoniales, sacerdotes de la dicha edad de quarenta años o más e suficientes, que en tal caso se prefiera el que dellos fuere fallado más suficiente». 
clérigos estudiantes del obispado burgalés, a los que él no quiso dar órdenes sagradas por su insuficiencia (en edad,honestidad y ciencia) o por falta de título beneficial, conseguían de Roma reverendas, letras dimisorias, para poder ser ordenados por otros obispos, los cuales, sin tener mejor constancia de su idoneidad, suficiencia y título, les ordenaban. Luego, los así ordenados, «siendo como son ignorantes e personas de poco saber, se atreuen, executando las dichas órdenes, a cantar e cantan epístola, euangelio, e missa en las dichas yglesias donde son patrimoniales, o en otras deste dicho nuestro obispado" ${ }^{294}$.

El obispo tenía dónde elegir y el examen de los ordenandos funcionaba. Lo cual no quiere decir que, al estilo de los aquí mencionados, no hubiese también otros de cortos alcances. En ese mismo sínodo de 1500 se alude a ciertos abusos en la obtención de letras apostólicas, así como en la interpretación de las mismas, aprovechándose de la ignorancia de aquellos a quienes se encomienda su ejecución; es decir, que los tales no entendían el latín ${ }^{295}$.

El interés del obispo Pascual de Ampudia en que las iglesias estén servidas por personas doctas se manifiesta nuevamente en el sínodo de 1511 .

En el título De institutionibus se aquilata con medidas muy concretas la provisión de vacantes en las iglesias numeradas, en las que la nominación y presentación para beneficios de ración y media ración correspondía a los curas y clérigos de las mismas iglesias, los cuales se dejaban llevar por motivos de amistad o de parentesco y por otras razones no suficientes, no canónicas.

El sínodo dispone que se presente a un clérigo idóneo, conforme al orden siguiente: para ración entera, al medio racionero más antiguo en el beneficio; para media ración, al cuartillero más antiguo en el beneficio; y para cuarta ración, al hijo patrimonial más hábil y suficiente.

Pero, en todos esos casos se tendrá en cuenta, a los efectos de antigüedad, que los clérigos de las iglesias en cuestión, que están estudiando en un estudio general, se consideran residentes en sus propias iglesias.

Este privilegio se justifica expresamente por la importancia de que las iglesias sean provistas de personas doctas ${ }^{296}$.

294 Título De los que se ordenan fuera deste obispado (López Martínez 368).

295 Título De las gracias apostolicas e otras letras (López Martínez 367-368): «Por quanto hauemos sido informado, e nos consta, que algunas personas traen e presentan en nuestro obispado letras e gracias para hauer e conseguir por ellas beneficios patrimonales, ganadas con no ciertas ni verdaderas relaciones, e a las vezes tales que no se estienden a los dichos beneficios, e que las tales personas son instituydos en ellos illícitamente, a causa que los subesecutores a quien se comete la prouisión dellos no las entienden ni saben a qué ni quánto se estienden.... .

296 López Martínez 401-402: «Otrosí, hemos visto en este nuestro cbispado que ay 
Podemos concluir que en la diócesis de Burgos, por lo menos a finales del siglo XV y principios del XVI, había no pocos clérigos estudiando en Estudio General, y no había problema preocupante de ciencia clerical; si bien es cierto que algunas iglesias estaban servidas por personas menos doctas. En cualquier caso, no existía, propiamente, problema de insuficiencia o ignorancia, sino de mayor o menor suficiencia.

Abreviaturas de referencias bibliográficas utilizadas

Aguilafuente = El APRENDIZ DE BIBliofilo, El Sinodal de Aguilafuente, I. Facsimil del incunable, Madrid, 1965.

Bajet i Royo = Eduard BAJET Y RoYO, Las constituciones sinodales del obispo de Barcelona Ferrer de Abella (1334-1345), «Ciencia Tomista” 106 (1979), pp. 263-283.

Buesa Conde $=$ D.J. Buesa CONDE, Los sínodos de Huesca-Jaca en el siglo XIII, «Aragón en la Edad Media», vol. II. Estudios de Economía y sociedad (siglos XII al XV) (Zaragoza, 1979), PP. 73-96. Recoge y glosa las rúbricas, pero no da el texto sinodal, que ofrece en su tesis de licenciatura, de la que ignoro si circula ya impresa.

Bujanda = Fernando BuJANDA, Documentos para la historia de la diocesis de Calahorra. Tres sínodos del siglo XIII, «Berceo», 1 (1946), Pp. 121-135.

COD $=\mathrm{J}$. Alberigo et ALII (editores), Conciliorum Oecumenicorum Decreta, ed. 32, Bologna, 1973.

García = Antonio Garcín y Garcín (editor), Constitutiones Concilii quarti Lateranensis una cum Commentariis Glossatorum, Città del Vaticano, 1981.

algunas yglesias que son numeradas... e, avnque según derecho e buena consciencia son obligados a nos presentar el hijo patrimonial más ydóneo... hemos visto muchas vezes lo contrario, a causa de amistades e parentesco e otras razones... Por ende... sean obligados los dichos curas e clérigos a nos presentar, si es para ración entera, al medio racionero primero entrado que estouiere residente en la dicha yglesia, con que sea ábile, e esso mesmo dezimos en la vacación de la media ración quanto a los quartilleros, e en la quartilla sea proueydo el hijo patrimonial que más ábile e suficiente fuere hallado. Pero... si alguno destos proueydos en las tales yglesias estouiere estudiando en estudio general, que pues es acto virtuoso e porque las yglesias sean proveydas de personas doctas, que los tales sean hauidos como si residiessen en sus propias yglesias, e gozen desta preheminencia como los residentes e interessentes». 
Hillgarth-Silano $=$ J.N. HILLGARTH - Giulio SilaNo, $A$ compilation of the diocesan synods of Barcelona (1354): critical edition and analysis, «Mediaeval Studies», 46 (1984), pp. 78-157.

Linehan $=$ Peter A. Linehan, Pedro de Albalat y su $<<$ Summa Septem Sacramentorum > >, «Hispania Sacra», 22 (1969), pp. 9-30.

López Martínez = Nicolás LOPEZ MARTINEZ, Sinodos burgaleses del siglo $X V$, «Burgense», 7 (1966), pp. 211-406.

Martín-Linage $=$ José Luis MARTíN - Antonio LINEHAN, Religión y sociedad Medieval. El catecismo de Pedro de Cuéllar (1325), Salamanca, 1987.

Noguer-Pons $=$ T. Noguer I Musqueras - J.M. Pons Guri, Constitucions sinodals de Girona de la primera compilacio, «Anales del Instituto de Estudios Gerundenses», 18 (1966-1967), Pp. 49-212.

Ochoa = José María OCHOA MARTINEZ DE SORIA, Los dos sínodos de Zaragoza bajo el pontificado de D. Pedro Lz. de Luna (1317-1345) y Los sinodos de Zaragoza promulgados por el arzobispo don Lope Fernández de Luna (1361-1382), «Scriptorium Victoriense», 2 (1955), Pp. 118-159 y 311370.

Pamplona $=$ Constitutiones sinodales Diocesis Pampilonensis una cum compendio Sacramentorum, Pamplona, 1501.

Pons Guri = J.M. Pons GURI, Constitucions conciliars tarraconenses (1229 a 1330), «Analecta Sacra Tarraconensia», 47 (1974), pp. 65-128; y 48 (1975), pp. 241-363. En las citas utilizo la paginación propia del artículo: pp. 1-187; no la de la revista, aquí anotada.

Sáenz de Aguirre = J. SAENZ DE AGUIRre, Collectio Maxima Conciliorum Hispaniae et Novi Orbis, Vol. V, Romae, 1755.

San Martín = J. San Martín, Sínodos Diocesanos del Obispo D. Vasco (1344-1352), «Publicaciones de la Institución Tello Tèllez de Meneses», 2 (1949), pp. 129-173. 1962.

Sanabre = José SANABRE, Los sinodos diocesanos en Barcelona, Barcelona,

Sánchez Herrero $=$ José SÁnChez Herrero, Concilios Provinciales $y$ 
Sínodos Toledanos de los siglos XIV y XV. La religiosidad cristiana del clero y pueblo, La Laguna, 1976.

Sanchis Sivera I-II = José SANCHIs SIverA, Para la bistoria del derecho eclesiástico valentino, "Analecta Sacra Tarraconensia», 9 (1933), Pp. 137-147 (I); 10 (1934) 123-149 (II).

SH I-V = Synodicon Hispanum. Edición crítica de los sínodos hispanos celebrados entre 1215 y 1563, dirigida por Antonio García y García y publicada en la Biblioteca de Autores Cristianos (BAC; Madrid 1981-). Han aparecido cinco volúmenes: I. Galicia (1981); II. Portugal (1982); III. Astorga, León y Oviedo (1984); IV. Ciudad Rodrigo, Salamanca y Zamora (1987); V. Badajoz, Coria y Plasencia (1990).

Tejada = Juan Tejada Y RAmiro, Colección de Cánones y de todos los Concilios de la Iglesia Española, vol. III, Madrid, 1851.

Villanueva = Jaume Villanueva, Viage literario por las Iglesias de España, vol. XVI: Viage a Lérida, vol. XVII: Viage a Lérida y Barcelona, Madrid 1851.

\section{RESUME}

L'analyse de la littérature destinée au soin des âmes, c'est-à-dire des traités de théologie pratique et des normes synodales, du Bas Moyen-Age espagnol, en relation avec la culture religieuse du clergé paroissial, fait remarquer que l'autorité ecclésiastique exigeait un niveau minimum de connaissance pour ce qui concernait les trois tendances du savoir: connaissance des Ecritures et de la discipline ecclésiastique, connaissance des sciences profanes et connaissance des thèmes mondains. Plus concrètement cette exigence minime se matérialise pour tout le clergé par: savoir lire, chanter (plain-chant, musique religieuse) et connaître la grammaire; et se résume fréquemment dans des phrases telles que "savoir parler latin" et «être grammairien». En plus le clergé préparé devra savoir, au moins dans sa formation la plus élémentaire, la doctrine chrétienne pour administrer les sacraments et enseigner la foi au peuple qui lui est confié. D'autre part cette analyse nous permet d'aborder des situations d'application ou d'inaccomplissement de cette exigence minimale dans les divers diocèses, conformément aux circonstances socio-politiques et religieuses. Les principales sources de référence littéraires qui son analysées ici sont, à côté de la tradition ecclésiastique (saints canons), le Concile IV de Latran (1215), les conciles des légats de Valladolid (1228 et 1322) et de Lérida (1229), ainsi que les constitutions provinciales et diocésaines antérieures à chaque synode en question. 


\section{SUMMARY}

The analysis of the literature intented for the healing of souls, which means the treaties of practical theology and norms of the synods, of the low Spanish Middle Ages, related to the religious culture of the parochial clergy, reveals that the ecclesiastical authorities demand a minimum level of requirement as far as the three facets of knowledge are concerned: knowledge of the Holy Scriptures and ecclesiastical discipline, knowledge of profane sciences and knowledge of society people affairs. More concretely, this minimum level of demand means for the whole of the clergy to be able to read, sing (plainsong, religious music) and to mastergrammar. It is often resumed in sentences like «to be able to speak latin" and «to be a grammarian". Moreover, prepared priests had to know, at least in its most elemental formulation, the christian doctrine to administrate sacraments and teach faith to the population entrusted to them. On the other hand, this analysis allows us to get nearer to the situation of fulfilment and non-fulfilment of this minimum requirement in the different dioceses, according to socio-political and religious circumstances. The basic sources of reference of literature analysed here are, with the ecclesiastical tradition (holy canon law), the IV Letrano Council (1215), the councils of legates in Valladolid (1228 and 1322) and in Lérida (1229), and province and diocese constitutions dating from before the mentioned synod. 